Adriana de Souza VieIRa

\title{
LIMITES À NEGOCIAÇÃO INDIVIDUAL NO CONTRATO DE TRABALHO
}

\author{
DisSERTAÇÃO DE MESTRADO \\ ORIENTADOR: PROF. DR. ARI POSSIDÔNIO BELTRAN \\ UNIVERSIDADE DE SÃo PAULO \\ SÃO PAULO \\ 2012
}




\section{Adriana de Souza Vieira}

\section{LIMITES À NEGOCIAÇÃO INDIVIDUAL NO}

\section{CONTRATO DE TRABALHO}

Dissertação apresentada à Banca Examinadora da Faculdade de Direito da Universidade de São Paulo como exigência parcial para a obtenção do título de Mestre em Direito do Trabalho e da Seguridade Social, sob orientação do Professor Doutor Ari Possidônio Beltran.

Área de concentração: Direito do Trabalho e da Seguridade Social. 


\section{Adriana de SoUZa Vieira}

\section{LIMITES À NEGOCIAÇÃO INDIVIDUAL NO CONTRATO DE TRABALHO}

Dissertação apresentada à Banca Examinadora da Faculdade de Direito da Universidade de São Paulo como exigência parcial para a obtenção do título de Mestre em Direito do Trabalho e da Seguridade Social, sob orientação do Professor Doutor Ari Possidônio Beltran.

Área de concentração: Direito do Trabalho e da Seguridade Social.

Data de aprovação:

Nome:

Título:

Instituição:

Nome:

Título:

Instituição:

Nome:

Título:

Instituição: 


\section{DEDICATÓRIA}

A todos os que comigo compartilham a paixão pelo direito do trabalho. 


\section{AGRADECIMENTOS}

Aos meus amados pais, que com imensurável amor, ensinaram-me a ser persistente e corajosa para suportar as provas da vida, além de me inspirarem a ser cada vez melhor.

Às minhas queridas irmãs, Giovana e Viviane, que sempre e para sempre juntas de mim, compartilharam comigo todos os êxitos e percalços de minha trajetória.

Ao meu marido, que com seu amor, incentivo e paciência tem acompanhado meus passos todos esses anos, completando minha vida em todos os sentidos.

A todos os mestres e colegas desta Faculdade, que me transmitiram a paixão pelo Direito e por estas Arcadas; em especial, ao meu orientador, Professor Ari Possidônio Beltran, pela oportunidade acadêmica.

Por fim, agradeço às dificuldades que enfrentei, pois sem elas eu não teria saído do lugar. 


\title{
RESUMO
}

O contrato de trabalho é expressão da autonomia privada individual dos sujeitos da relação de emprego. Como poder de autorregulamentar os próprios interesses, referida autonomia submete-se às disposições do ordenamento jurídico desde a formação, até a extinção da relação contratual. Na prática, tais disposições impõem muitas limitações ao poder de livre estipulação das partes, pois resultam da conjugação de inúmeros fatores, especialmente de ordem econômica e social, os quais demonstraram a precariedade dos dogmas do liberalismo, levando-o ao seu naufrágio. A partir de então, com o objetivo de realizar a função social dos contratos, o Estado interveio nas relações entre os particulares, moldando amplamente o conteúdo dos pactos laborais por meio da lei. Há quem afirme, nesse sentido, que, no âmbito das relações de trabalho, o Estado tudo pretendeu regular, uma vez que limites à autonomia privada estariam evidentes no ordenamento jurídico. Destaque-se que não apenas a lei, em sentido estrito, é considerada fonte de limitação, sendo esse papel desempenhado por todas as normas, positivadas ou não; autônomas ou heterônomas, que integram o ordenamento jurídico e estão relacionadas à ordem pública. Mais além, no âmbito das relações de trabalho, os avanços tecnológicos, científicos e econômicos revelaram situações nas quais é completa a omissão do legislador, desaparecendo a evidência dos limites a serem observados. Nessas hipóteses, incumbe ao operador do direito investigar eventual (in)existência de restrições à livre pactuação no ordenamento jurídico como um todo.

Palavras-chave: Contrato; Autonomia privada; Limites.

\begin{abstract}
The employment contract reflects the individual private autonomy of each party in a laboral relationship. As a power of self-regulate their own interests, the individual private autonomy submits itself to the legal provisions since the formation until the end of the contract. In practice, these provisions impose many limitations on the power of free stipulation of the parties. Limitations came from many factors, especially economic and social order, what demonstrated the precariousness of liberalism and led to the sinking of this doctrine dogmas. Thereafter, the State, in order to perform the social function of contracts, intervened in relations between individuals, largely shaping the content of employment agreements by law. Some say that the State intended, by this gesture, to regulate everything in employment relationships because the limits of individual private autonomy would be evident in the legal system. It is noteworthy that not only the law, strictly speaking, is considered a source of limitation, once this role is played by all rules positive or not, autonomous or heteronomous - that belong to the legal system and are related to public order. Further, in the context of labor relations, technological, scientific and economic advances revealed situations in which is the complete omission of the legislator, disappearing evidence of limits to be observed; in these cases, the operator is responsible for the investigation about the existence or lack of restrictions on power of self-regulation in entire legal system.
\end{abstract}

Keywords: Contract; Private autonomy; Limitation. 
"Entre o forte e o débil, é a liberdade a que mata e a lei a que redime".

Lacordaire 


\section{SUMÁRIO}

1. INTRODUÇÃO ....................................................................................... 10

2. A CONTRATUALIZAÇÃO DAS RELAÇÕES DE TRABALHO: EVOLUÇÃO

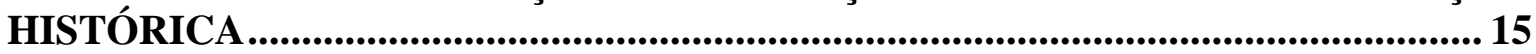

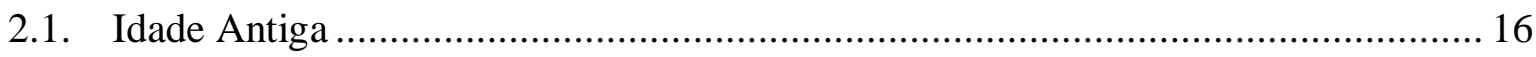

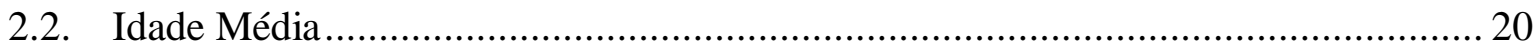

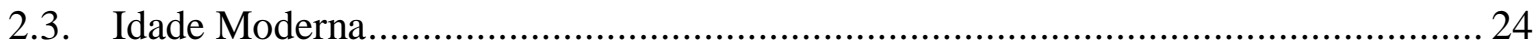

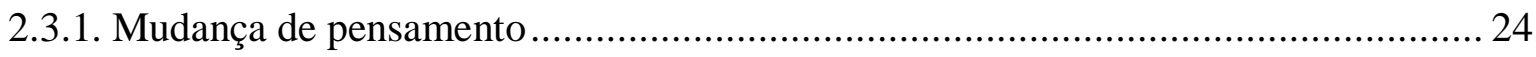

2.3.2. Mudanças no processo produtivo e no campo econômico ....................................... 26

3. CONTRATO INDIVIDUAL DE TRABALHO: PRINCIPAIS ASPECTOS

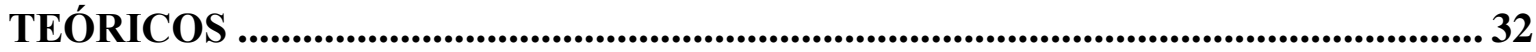

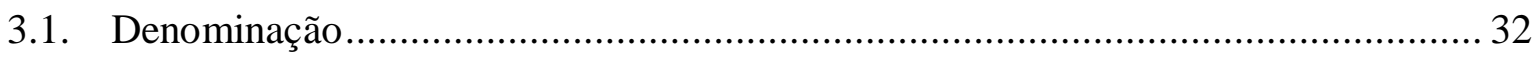

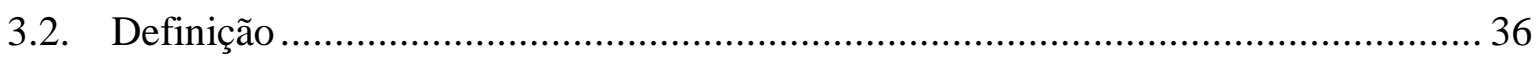

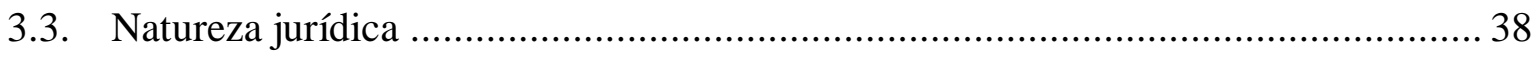

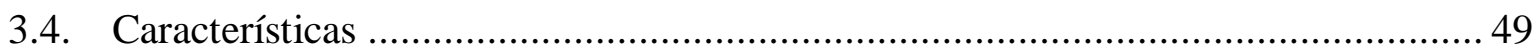

3.4.1. Elementos fático-jurídicos da relação de emprego ............................................... 54

4. AUTONOMIA DA VONTADE E AUTONOMIA PRIVADA........................... 61

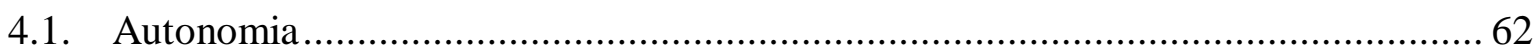

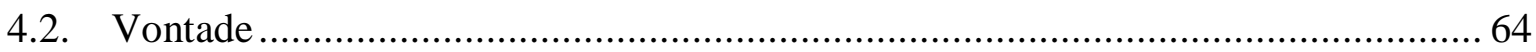

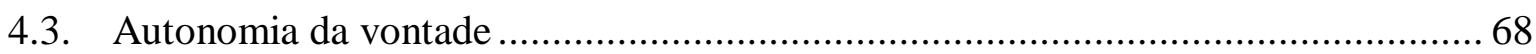

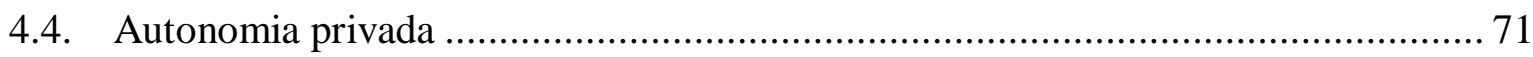

4.5. Relação entre autonomia privada e autonomia da vontade.................................. 74

5. LIMITES À AUTONOMIA PRIVADA NO DIREITO DO TRABALHO ......... 80

5.1. A ordem pública como a primeira fonte de limitações ........................................ 82

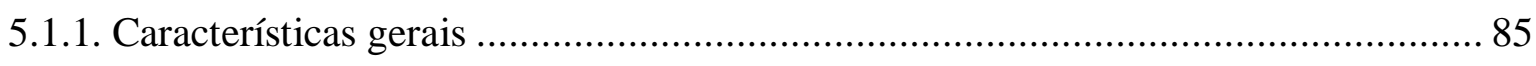

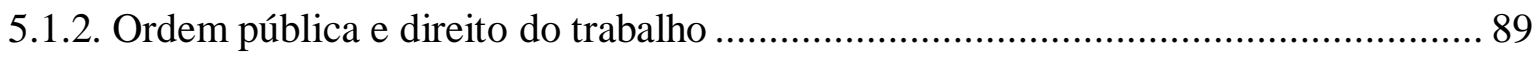

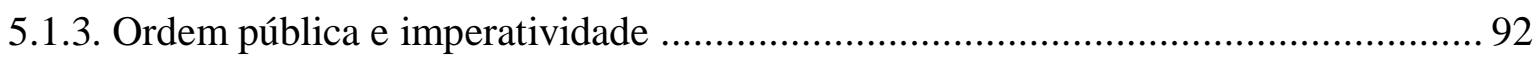

5.2. Principais instrumentos de regulamentação e limitação utilizados pelo direito do

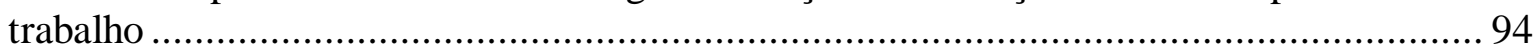

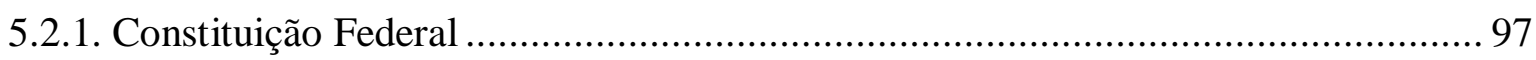

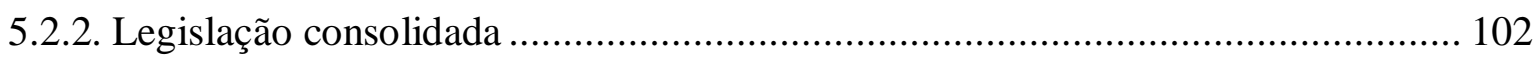


5.2.5. Normas coletivas

5.2.6. Jurisprudência.

6. A CLÁUSULA DE NÃO-CONCORRÊNCIA NO DIREITO DO TRABALHO: QUAIS OS LIMITES À AUTONOMIA PRIVADA INDIVIDUAL?

6.1. Liberdade de trabalho versus a cláusula de não-concorrência 119

6.2. Dever de não-concorrência e cláusula de não-concorrência: distinção necessária . 122

6.3. Análise geral da cláusula de não-concorrência no direito do trabalho estrangeiro e no

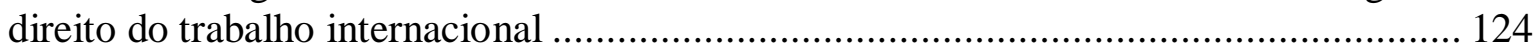

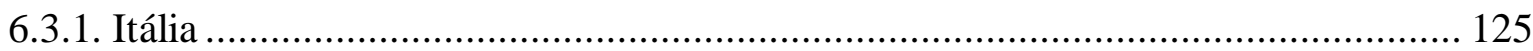

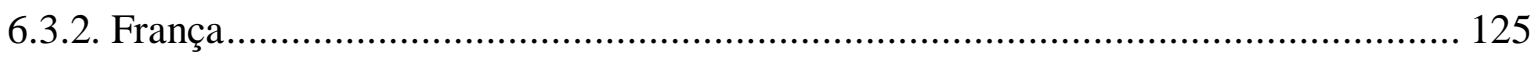

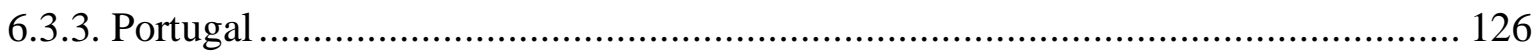

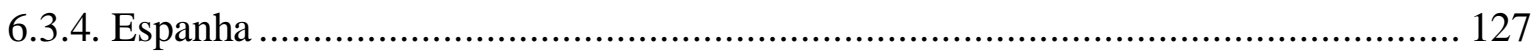

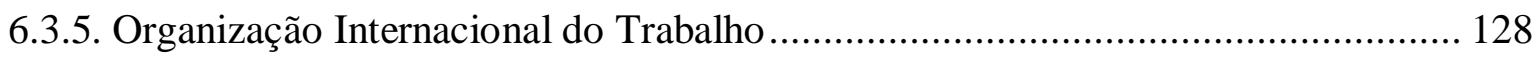

6.4. A cláusula de não-concorrência no direito do trabalho brasileiro ......................... 128

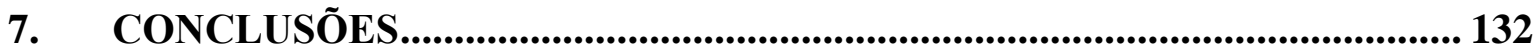

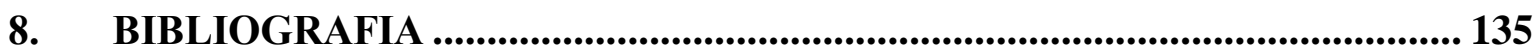




\section{INTRODUÇÃO}

A presente pesquisa tem por objetivo desvendar os limites da autonomia privada das partes no âmbito do contrato individual de trabalho. Sendo a negociação o instrumento por meio do qual a autonomia das partes se manifesta, as limitações sobre ela incidentes nas relações trabalhistas restringem a via negocial, quer na formação do vínculo de emprego, quer durante seu desenvolvimento, quer, ainda, em sua extinção, justificando-se, assim, a escolha desse tema.

Para a análise aqui pretendida, o contrato de trabalho ocupa posição de destaque, sendo relevante a investigação de sua origem e evolução, bem como de seus principais aspectos teóricos. Não se pretende, por óbvio, esgarçar, em sua totalidade, a figura jurídica do contrato de trabalho, contudo, faz-se necessário o levantamento de seus principais aspectos, de modo a fornecer uma visão geral do tema. Por esse motivo, a abordagem das limitações à autonomia privada no âmbito do contrato individual de trabalho será precedida da exposição dos principais aspectos do instrumento jurídico sobre o qual elas incidem.

Saliente-se que as razões para as referidas limitações são encontradas na própria história do contrato de trabalho, a qual se confunde com a história da liberdade do homem na esfera das relações laborais, cujo apogeu deu-se com a regulamentação do trabalho subordinado pelo Estado. A análise de tais limitações será importante, sobretudo, para traçar as bases do atual sistema jurídico, composto por grande número de normas imperativas, sejam elas decorrentes de fontes heterônomas ou autônomas, além de outras tantas de índole dispositiva, sendo o contrato de trabalho fundado na autonomia privada das partes.

De acordo com o clássico paradigma do direito do trabalho, a imposição de normas imperativas para estabelecer condições laborais mínimas - e, consequentemente, limites à autonomia privada das partes - foi a forma encontrada para buscar o necessário equilíbrio de importantes valores do Estado Democrático de Direito: a liberdade de iniciativa e a valorização do trabalho do homem.

Como observa Estêvão Mallet, tais limites variam conforme o momento histórico, a natureza da relação jurídica em causa e a particular condição dos sujeitos envolvidos. Em alguns casos, serão mais tênues, ampliando o espaço reservado à 
autonomia privada das partes; em outros, mais intensos, imprimindo padrões mais rígidos e pré-definidos à relação jurídica. ${ }^{1}$ Por fim, em algumas zonas consideradas cinzentas, não estão claramente dispostos, sendo que a busca pela solução jurídica adequada exigirá do operador do direito a ponderação dos valores e princípios fundamentais do sistema como um todo.

Mais além, em um momento em que temas como globalização, avanço do desemprego e flexibilização dominam a pauta dos operadores do direito do trabalho, a discussão sobre a extensão desses limites restringe-se ao seu aspecto coletivo, ou seja, a possibilidade de livre pactuação é discutida tão somente no cenário dos atores sociais que exercem a autonomia coletiva dos particulares. Isso porque, no Estado Democrático de Direito, há inegável prestígio da autonomia coletiva, reconhecendo-se as atribuições e o poder normativo dos grupos sociais organizados para regular seus próprios interesses. Ao lado das normas originadas da produção estatal e daqueles provindas de decisões judiciárias, há pródiga fonte de produção normativa decorrente das convenções e acordos coletivos, chamadas fontes autônomas de direito. ${ }^{2}$

No Brasil, a negociação coletiva foi estimulada pela Constituição Federal de 1988, como pode ser observado da redação de diversos incisos de seu artigo $7^{\circ}$, pertencente ao capítulo dos direitos sociais: no VI, prevê-se irredutibilidade de salário, salvo o disposto em convenção ou acordo coletivo; no XIII, duração do trabalho normal não superior a oito horas diárias e quarenta e quatro semanais, facultada a compensação de horários e a redução da jornada, mediante acordo ou convenção coletiva de trabalho; no XIV, jornada de seis horas para o trabalho realizado em turnos ininterruptos de revezamento, salvo negociação coletiva; enquanto no XXVI, reconhece-se as convenções e acordos coletivos de trabalho. A Carta Constitucional prestigiou a negociação coletiva também na resolução de conflitos coletivos entre trabalhadores e empregadores, estabelecendo a prioridade da solução negociada entre as próprias partes envolvidas no conflito, antes do ajuizamento de dissídio coletivo de natureza econômica, conforme

\footnotetext{
Contrato de trabalho, autonomia privada e remuneração; formas de remuneração variável; remuneração variável sujeita a revisão periódica; interpretação do contrato de trabalho; conduta das partes e conteúdo da contratação. In Prática de Direito do trabalho. São Paulo: LTr, 2008. p. 16-17.

2 BELTRAN, Ari Possidônio. Dilemas do trabalho e emprego na atualidade. São Paulo: LTr, 2001. p. 122-123.
} 
dispõe os parágrafos $1^{\circ}$ e $2^{\circ}$, do artigo 114 , que trata da competência material da Justiça do Trabalho. $^{3}$

Diante desse cenário, incontáveis estudos doutrinários hoje se dedicam a desvendar os limites da negociação trabalhista - em muitos casos, propugnando pela sua supressão - em âmbito coletivo, especialmente pela abordagem do fenômeno da flexibilização. Discute-se, por exemplo, se a negociação coletiva autorizada pelo texto constitucional estaria ou não limitada pelo estatuído no artigo 468, da Consolidação das Leis do Trabalho, que prevê a inalterabilidade do contrato de trabalho em prejuízo do empregado, ${ }^{4}$ ainda que por mútuo consentimento.

Sem prejuízo de tais questões, timidamente, conflitos individuais, envolvendo situações não regulamentadas pelo direito do trabalho, passaram a demandar soluções jurídicas, após o sistema demonstrar incertezas quanto aos limites da negociação individual no contrato de trabalho. Não obstante houvesse o legislador trabalhista pretendido regulamentar de maneira completa e eficaz as relações laborais, verifica-se completa omissão diante de novas realidades impostas pela evolução social, científica e tecnológica, como no caso da cláusula de não-concorrência inserida nos contratos individuais de trabalho.

Nesse ponto, evidencia-se a importância prática e teórica deste estudo, pois a resolução de tais questões exige do operador do direito perfeita compreensão do ordenamento jurídico laboral, com apreensão dos valores fundamentais que o constituem, bem como dos instrumentos de que se utiliza para garantir a efetiva tutela dos trabalhadores. Ressalte-se que o estudo será focado na negociação individual do contrato de trabalho e somente adentrará na seara da negociação coletiva quando necessário algum contraponto ou esclarecimento adicional sobre determinado aspecto ou, ainda, na análise dos instrumentos coletivos como fonte de limitação da autonomia privada individual.

\footnotetext{
${ }^{3}$ Art. 114. (...) $\S 1^{\circ}$ - Frustrada a negociação coletiva, as partes poderão eleger árbitros; $\S 2^{\circ}$ Recusando-se qualquer das partes à negociação coletiva ou à arbitragem, é facultado às mesmas, de comum acordo, ajuizar dissídio coletivo de natureza econômica, podendo a Justiça do Trabalho decidir o conflito, respeitadas as disposições mínimas legais de proteção ao trabalho, bem como as convencionadas anteriormente.

${ }^{4}$ Destaque-se a colocação de Arnaldo Süssekind, favorável ao fenômeno da flexibilização: "Revela ponderar, finalmente, que, nas hipóteses de flexibilização autorizadas pela Constituição brasileira, não mais poderá ser invocado o estatuído no art. 468 da CLT, alusivo à inalterabilidade do contrato de trabalho. É que, por meio de convenções ou acordo coletivo, nos casos previstos no art. $7^{\circ}$ da Lex Fundamentalis, o sindicato poderá dispor de direitos individuais de empregados por ele representados." (Cf. SÜSSEKIND, Arnaldo; MARANHÃO, Délio; VIANNA, Segadas e TEIXEIRA, Lima. Instituições de direito do trabalho. V. I, São Paulo: LTr, 1999. p. 216)
} 
A análise do tema central do presente trabalho será precedida de abordagens secundárias, mas não menos relevantes que, em linhas gerais, percorrerão a materialização da autonomia privada no âmbito do direito do trabalho, definição e a revisitação do conceito de ordem pública pela legislação laboral.

Assim, o primeiro capítulo será destinado ao estudo da evolução histórica da contratualização das relações de trabalho, pelo fato de ser o contrato de trabalho o instrumento jurídico em se que materializa a autonomia privada das partes. Serão expostas as razões sociais, econômicas, filosóficas e jurídicas que, no desenrolar dos fatos históricos, resultaram na afirmação do contrato de trabalho como um dos principais instrumentos de tutela dos seres humanos enquanto trabalhadores.

Em seguida, serão analisados os principais aspectos teóricos do contrato de trabalho, desde a análise da própria denominação, com exposição de suas principais características e teorias elaboradas pela doutrina sobre sua natureza jurídica, até sua consolidação no ordenamento jurídico pátrio.

Partir-se-á, então, para a delimitação dos contornos da autonomia privada, a qual será precedida da abordagem singularizada dos elementos que a compõem o princípio sobre o qual ela se baseia, qual seja, a autonomia da vontade, além da própria definição deste.

Superadas essas etapas, consideradas introdutórias, passar-se-á à análise dos limites propriamente ditos que o ordenamento jurídico impõe à autonomia privada dos sujeitos da relação de trabalho, com ênfase para a negociação individual do contrato de trabalho.

Finalmente, abordar-se-á a figura da cláusula de não-concorrência no ordenamento jurídico brasileiro, as quais têm sido inseridas nos contratos individuais de trabalho celebrados em território nacional, não obstante a completa omissão do legislador. Nesse contexto, a análise dos parâmetros que conferem validade a esse tipo de cláusula no ordenamento jurídico pátrio, envolve, substancialmente, a averiguação dos limites a que está sujeita a autonomia privada dos sujeitos da relação de emprego.

Importa observar, finalmente, que o método bibliográfico utilizado é o regulamentado pelas normas da Associação Brasileira de Normas Técnicas para trabalhos acadêmicos, adaptado às peculiaridades dos estudos jurídicos. A identificação das obras referentes às transcrições constantes do trabalho será apresentada em notas de 
rodapé, e não no próprio texto, entre parênteses, como determinam as atuais regras da Associação Brasileira de Normas Técnicas. Nas hipóteses em que apenas uma obra de determinado autor foi citada, utilizou-se apenas a expressão "Op. cit.", seguida da indicação da(s) páginas(s) da obra, repetindo-se a citação completa na Bibliografia; havendo multiplicidade de obras do mesmo autor, optou-se por indicar as primeiras palavras do título da obra, antes da expressão “Op. cit.”, seguida da indicação da(s) página(s). Foram observadas, ainda, as regras constantes na Resolução $\mathrm{n}^{\mathbf{0}} 1$, da Comissão de Pós-Graduação da FADUSP, estabelecida na reunião de 10 de setembro de 2002, que dispõe sobre a editoração padronizada de dissertações, teses e trabalhos de pesquisa. 


\section{A CONTRATUALizaÇÃo dAS RELAÇÕES DE TRABALHO: EVOLUÇÃO HISTÓRICA}

A evolução histórica do contrato de trabalho confunde-se com a evolução histórica da própria liberdade do homem nas relações de trabalho. Isso porque nem sempre os homens admitiram que tais relações fossem juridicamente reguladas, por lei ou contrato, e que previssem direitos e obrigações recíprocas.

Em Roma, pelo fato de o trabalho ser executado por escravos, então considerados objetos, as relações trabalhistas baseavam-se no direito real. Já na Idade Média, pode-se dizer que as relações de servidão fundamentavam-se no direito pessoal, pois, embora o trabalho fosse livre, era prestado pelo servo, em troca da proteção e assistência do senhor feudal. Apenas na Idade Moderna, por meio do trabalho subordinado, as relações de trabalho passaram a ser baseadas no direito obrigacional, de natureza patrimonial.

Arion Sayão Romita define o trabalho subordinado como o trabalho prestado em regime de liberdade contratual, lastreado na autonomia da vontade. ${ }^{5}$ Implica, assim, uma relação jurídica específica, em torno da qual foi construído um universo de institutos, princípios e regras, que materializaram o próprio direito do trabalho. A esse respeito, observa António Monteiro Fernandes:

[...] o direito do trabalho tem o seu campo de atuação delimitado pela situação de trabalho subordinado. E esta delimitação é feita em termos práticos pela conformação de um certo tipo de contrato que é aquele em que se funda a prestação de tal modalidade de trabalho: trata-se do contrato individual de trabalho ou, mais corretamente, contrato de trabalho. ${ }^{6}$

O estudo da evolução histórica do contrato de trabalho, desse modo, se relaciona diretamente com o estudo da evolução histórica do próprio trabalho

\footnotetext{
${ }^{5}$ Cf. ROMITA, Arion Sayão. A subordinação no contrato de trabalho. Rio de Janeiro: Forense, 1979. p. 11-13.

${ }^{6}$ Direito do trabalho. $13^{\mathrm{a}}$ ed., Coimbra: Almedina, 2007. p. 127.
} 
subordinado, já que é por meio deste que "uma pessoa singular se obriga, mediante retribuição, a prestar a sua atividade a outra ou outras pessoas, no âmbito de organização e sob a autoridade destas”, conforme a definição clássica de contrato de trabalho adotada pelo Código do Trabalho de Portugal, com as alterações promovidas pela Lei $\mathrm{n}^{\mathrm{o}} 7$, publicada em 12 de fevereiro de 2009.

Sem prejuízo das discussões em torno da origem histórica do contrato de trabalho, fato é que, moldes atuais, tal figura tem origem recente, não ultrapassando duzentos anos. Seu surgimento resultou das duas grandes revoluções que marcaram a Idade Moderna: a Industrial, no final do século XVIII e início do século XIX, que alterou profundamente a economia, o modo de produção e, consequentemente, as relações entre capital e trabalho; e a Revolução Francesa, em 1789, responsável pelas transformações no campo político, social e ideológico. O contrato de trabalho típico, derivado desses acontecimentos, fundamenta-se na ideia do trabalho livre e da igualdade formal entre as pessoas. ${ }^{7}$ Tal instrumento jurídico tornou-se um dos pilares mais significativos da caracterização da cultura sociojurídica do mundo ocidental. ${ }^{8}$

\subsection{Idade Antiga}

Apesar da origem recente, as raízes do contrato de trabalho são encontradas na Idade Antiga, mais especificamente, no direito romano. ${ }^{9}$ A sociedade romana assentava-se no trabalho de colonos e escravos e, em princípio, seria possível imaginar que o contrato de trabalho não teria sentido em uma sociedade escravagista. Como os escravos não possuíam liberdade na prestação de serviços, não seria necessário nenhum instrumento jurídico para regulamentar a relação estabelecida entre eles e seus senhores.

Trabalho, nesse período, tinha uma concepção diferente da atual, menos universal e até pejorativa. Na época, designava o exercício a que apenas os pertencentes ao mais baixo escalão da sociedade se dedicavam, cedendo sua força de

\footnotetext{
${ }^{7}$ ROMITA, Arion Sayão. Flexigurança - A reforma do mercado de trabalho. São Paulo: LTr, 2008. p. 15. ${ }^{8}$ DELGADO, Mauricio Godinho. Curso de direito do trabalho. 6 a ed., São Paulo: LTr, 200. p. 490.

${ }^{9}$ Nesse aspecto, diverge Otto Von Gierke, para quem a origem do contrato de trabalho estaria no contrato de serviços alemão no instituto germânico denominado "contrato de serviço fiel". Cf. GÓMEZ-IGLESIAS CASAL, Angel. La influencia del derecho romano en las modernas relaciones de trabajo. Madrid: Civitas, 1995. p. 20-21 Apud MANNRICH, Nelson. A modernização do contrato de trabalho. São Paulo: LTr, 1998. p. 93.
} 
trabalho por meio de um negócio jurídico. Daí afirmar-se que políticos, médicos e filósofos, por exemplo, não trabalhavam, mas sim, ocupavam-se de seus afazeres. Escravos e soldados apenas obedeciam. Tal preconceito pressupunha uma distinção de classes, cuja valorização implicava riqueza fundiária, além de desprezo pelo trabalhador assalariado.

Mesmo se baseando no servilismo de escravos e colonos, a sociedade apresentava múltiplas situações de trabalho realizado por homens livres, ou seja, desprendidos de relações institucionalizadas de posse, domínio ou qualquer vinculação não decorrente da vontade de outros. ${ }^{10}$ Nesse cenário de sociedade escravagista, a utilização do contrato de trabalho como instrumento jurídico hábil a regulamentar a relação de trabalho livre não se justificava: como os escravos não possuíam liberdade na prestação de serviços, não seria necessário nenhum instrumento jurídico para regulamentar a relação estabelecida entre eles e seus senhores.

A despeito do desprestígio que sofriam, os homens que realizavam o trabalho livre tinham deveres sociais e, reconhecidamente, certa especialização. Os artesãos, por exemplo, que mantinham autonomia e um domínio técnico, obrigavam-se, juridicamente, à entrega de uma obra ou de um trabalho acabado e realizado encomendado por terceiros. Essa relação de trabalho correspondia a uma modalidade dos negócios jurídicos das locações (locatio conductio), previstas no Digesto, ${ }^{11}$ que versavam sobre o uso de objetos ou a prestação de atividades por pessoas, fosse o desenvolvimento de uma obra, fosse a força de trabalho dos trabalhadores livres.

A concepção de locatio conductio foi, inicialmente, considerada unitária, porém, após acirrado debate e sob a influência de glosadores e pandectistas, estabeleceu-se a divisão do instituto em três tipos: ${ }^{12}$ locatio conductio rei, correspondente à atual locação; locatio conductio operis, antecedente do contrato de empreitada, da chamada "locação de obra"; e locatio conductio operarum, que corresponde ao contrato de prestação de serviços, incluindo tanto o trabalho subordinado, quando o trabalho

\footnotetext{
${ }^{10} \mathrm{O}$ trabalho livre assalariado é mencionado numa tábua da época de Adriano (117-138), relativamente ao trabalho nas minas de Aljustrel; nessa tábua, quanto à mão-de-obra, alude-se ao emprego de mercenarii (trabalhadores livres assalariados) e servi (escravos) (Cf. MANGAS, Julio, El Trabajo em las Minas de La Hispania Romana, In: El trabajo através de la historia, Actas del $11^{\circ}$ Congreso de la Associación de Historia Social, Córdoba, Abril de 1995, org. por Santiago Castillo, Madrid, 1996. p. 52 e ss.) Apud MARTINEZ, Pedro Romano. Direito do trabalho. $3^{\mathrm{a}}$ ed., Coimbra: Almedina, 2006. p. 73-74).

${ }^{11}$ O Livro 19 trata da locatio nas três vertentes referidas. Além disso, no Digesto 38.1 encontram-se referências ao trabalho dos libertos.

${ }^{12}$ GÓMEZ-IGLESIAS CASAL, Angel. Op. cit., p. 124 Apud MANNRICH, Nelson. A modernização.... Op. cit., p. 93.
} 
autônomo. ${ }^{13}$ Em qualquer situação, uma das partes - o conductor - tinha de pagar à outra o locator - uma contrapartida em dinheiro, designada merces. Já no trabalho autônomo, a contrapartida em dinheiro era designada honorarium ou mesmo salarium. ${ }^{14}$

Assim, embora não houvesse uma separação precisa entre o tratamento destinado ao trabalho subordinado e ao trabalho autônomo, a locatio conductio operarum regulamentava a relação jurídica de trabalho prestado a outra pessoa e, segundo opinião majoritária, nela se encontram as bases do atual contrato de trabalho. ${ }^{15}$ Esse tipo de negócio jurídico incorporou um padrão específico de relacionamento interpessoal, garantindo o exercício privado da liberdade e da vontade.

A locação de serviços, que possibilitava a locação de escravos, considerados a própria res locada, seria resultado da evolução da locação de objetos e animais. Mais tarde, passaram também a ser objeto dela as operae que os libertos deviam a seus patronos. Contudo, tratava-se de uma figura abusiva, pois caracterizava os libertos como escravos.Extinta por um édito do pretor Rutilio e pela lei aelia sentia, passou-se a discutir a possibilidade de uma pessoa, livre desde seu nascimento, ceder seu trabalho em troca de merces.

Por razões de economia, naquele momento, a jurisprudência usou a mesma figura da locatio conductio. ${ }^{16}$ Júlio Manuel Vieira Gomes, citando Klaus Adomeit, afirma que o conhecimento dessa origem histórica explica a relativa persistência de se aproximar o contrato de trabalho ao da locação, verificada em alguns ordenamentos jurídicos. ${ }^{17}$ Como exemplos, Gomes aponta o primeiro projeto do Código Civil Alemão

\footnotetext{
${ }^{13}$ Quanto ao trabalho autônomo, Júlio Manuel Vieira Gomes considera que as chamadas "artes liberais" permaneciam fora da locatio conductio, e gozavam maior consideração social. Não por outra razão que, até hoje, haveria questionamentos quanto à compatibilidade da existência ou não de contrato de trabalho com certas profissões liberais, como por exemplo, a de advogado (Cf. GOMES, Júlio Manuel Vieira. Direito do trabalho - Relações individuais de trabalho. V. I. Coimbra: Coimbra, 2007. p. 18.)

${ }^{14}$ MARTINEZ, Pedro Romano. Op. cit., p. 73-75.

${ }^{15}$ De acordo com Nelson Mannrich, o autor Joaquim Pimenta diverge desse entendimento. Para ele, essa modalidade de locação, na história do Direito, lembra a locatio hominis ou a locação do escravo pelo senhor, como se dá hoje quando se aluga um animal. Tal concepção, portanto, migrou do trabalho escravo para o trabalho livre, dando origem à vinculação do trabalho do homem a uma coisa ou objeto passível de locação. Assim, "tal conceito não poderia servir de fundamento doutrinário a um contrato que, pela sua natureza intrínseca, isto é, de contrato bilateral, teria forçosamente de resultar do livre acordo das partes por supostas, uma ou outra, no mesmo nível de igualdade jurídica" (Cf. PIMENTA, Joaquim. Sociologia jurídica do trabalho. São Paulo: Max Limonad, 1944. p. 129 Apud MANNRICH, Nelson. A modernização.... Op. cit., p. 94).

${ }^{16}$ GOMES, Júlio Manuel Vieira. Op. cit., p. 17.

${ }^{17}$ ADOMEIT, KLAUS. Der Dienstvertrag des BGB und die Entwicklung zum Arbeitsrecht. NJW 1996. p. 1710 e ss. Apud GOMES, Julio Manuel Vieira. Op. cit., p. 17.
} 
(BGB), e o Código Civil Espanhol, em seu artigo 1542, que considera que "el arriendamento puede ser de cosas, o de obras, o servicios. " 18

Não obstante, de acordo com Maria do Rosário Palma Ramalho, embora seja unânime o reconhecimento da origem histórica remota do trabalho subordinado nas formas de prestação de trabalho livre verificadas na Antiguidade, a doutrina divide-se quanto à questão do momento em que o fenônemo se distancia desta sua origem para ser objeto de enquadramento jurídico específico. Para alguns autores, o trabalho subordinado, nos moldes atuais, é a manifestação moderna do fenônemo do trabalho dependente de épocas anteriores, sendo o atual contrato de trabalho uma projeção moderna locatio conductio operarum. ${ }^{19}$

Por outro lado, outros autores refutam essa origem romanística, defendendo que a moderna concepção de trabalho subordinado é um fenônemo recente, criado pela Revolução Industrial. Não obstante reconheçam que o trabalho subordinado livre em Roma era representado pela figura da locatio conductio, tais autores chamam a atenção para o fato de que, na sua origem, a figura romana envolvia, necessariamente, a transmissão temporária de um bem corpóreo a título oneroso, em qualquer de suas modalidades, trazendo implícita a idéia de "coisificação" da pessoa do trabalhador, com a consequente supressão de sua liberdade - ainda que temporária -, não se coadunando com o pressuposto essencial da liberdade do trabalhador, indispensável ao contrato de trabalho nos moldes atuais.

A partir de tal constatação, Maria do Rosário Palma Ramalho posiciona-se adepta à concepção do trabalho subordinado como um fenônemo moderno, projetado pela Revolução Industrial, não porque o trabalho dependente mas livre não existisse anteriormente, mas porque nas formas de trabalho pré-industrial o requisito da liberdade do prestador de serviços não tinha o significado axiológico pleno e irrestrito que hoje se lhe reconhece. ${ }^{20}$ Não obstante tal posicionamento, a autora reconhece a influência

\footnotetext{
${ }^{18}$ GOMES, Julio Manuel Vieira. Op. cit., p. 17.

${ }^{19}$ RAMALHO, Maria do Rosário Palma. Direito do trabalho - Parte I - Dogmática geral. $2^{\mathrm{a}}$ ed., Coimbra: Almedina, 2009. p. 42-43.

${ }^{20}$ Nesse sentido, a autora conclui: “(...) deste enquadramento do trabalho livre dependente na sociedade romana pela figura da 'locatio conductio operarum' não se pode concluir pela semelhança deste trabalho com o actual fenónemo do trabalho subordinado (...). Neste contexto, parece assim mais consentânea com os valores da época a ideia, sustentada por outros autores, de que nessa forma de 'locatio conductio', o trabalhador prescindia, na verdade, de uma parcela da sua liberdade e, ao locar a sua força de trabalho, locava, afinal, a sua própria pessoa, mediante um preço. Por outras palavras, a liberdade do prestador do trabalho tinha um valor relativo. Compreende-se assim o enquadramento jurídico do trabalho dependente não escravo pela figura da 'locatio conductio operarum', em Roma, mas no contexto social em que esse
} 
da locatio conductio operarum sobre o atual regime do contrato de trabalho, como denotam os seguintes traços por ela ressaltados:

- a locatio conductio integra o elenco das actiones de buona fidae, a que inere a característica da universalidade, que permite a celebração do contrato com não romanos; dado o objecto do negócio em causa (um trabalho 'vil', de acordo com as concepções sociais dominantes), este ponto era de grande importância para aumentar a incidência deste negócio;

- tratava-se de um negócio consensual;

- exigia-se a licitude da actividade do trabalhador;

- admitia-se a cessação do contrato por acordo das partes ou pela verificação de um termo;

- em algumas situações de não prestação de serviço o risco corria por conta do credor do serviço, que continuava obrigado ao pagamento da merces (esta característica antecipa as diversas situações de quebra do sinalagma contratual que se mantêm até hoje no contrato de trabalho). ${ }^{21}$

\subsection{Idade Média}

É na Idade Média, com a organização e regulamentação das corporações de ofício, que se verificam os primeiros pontos de contato com o atual direito do trabalho - o que não corresponde, como se verá, à perfeita identificação. Nesse período, o desenvolvimento das relações de trabalho decorreu, sobretudo, da preocupação com o progresso econômico. Não obstante os ideais cristãos propagados à época tenham atenuado o desprezo da sociedade pelo trabalho subordinado - pregando, por exemplo, a noção do

trabalho era desenvolvido e assente a relatividade da própria idéia de liberdade das pessoas no mundo antigo. Mas, naturalmente que, com esta configuração, aquela figura romana é de recusar como antecedente lógico do moderno contrato de trabalho" (Cf. Direito do trabalho - Parte I.... Op. cit., p. 46-47).

${ }^{21}$ Ibidem, p. 49-50. 
salário justo ${ }^{22}$ - a preocupação com o progresso econômico relegou para segundo plano as questões sociais. $^{23}$

As corporações de ofício, cujo apogeu deu-se por volta do século XIII, na Europa, marcaram esse período, modificando as relações entre os homens livres, pois se fundamentavam no trabalho subordinado. Elas agregavam os homens dedicados a um só ofício e tinham o objetivo de defender interesses e direitos relacionados à classe profissional, contra quaisquer pessoas ou entidades que pudessem colocar obstáculos à sua progressão e dignificação. Além disso, visavam à ajuda entre seus membros, em situações de dificuldades, como doença, invalidez ou falecimento, neste último caso, prestando auxílio aos familiares do associado. O grande desenvolvimento do associativismo profissional nesse período veio a ser chamado "corporativismo".

As corporações de ofício, além da notada influência no desenvolvimento do direito do trabalho, influenciaram outros ramos do direito, como o direito comercial e o direito penal. Em seus diversos regulamentos e regras precisas de orientação, encontram-se questões sobre concorrência desleal, especulação, falsificação de produtos, entre outros assuntos.

Especificamente ao direito do trabalho, interessam os preceitos que disciplinavam as corporações de ofício. Eles derivam dos usos e dos diversos regulamentos sobre aprendizagem, limitação da jornada laboral, descanso aos domingos e feriados, trabalho noturno, além de normas sobre dispensa de trabalhadores. ${ }^{24}$ Tais regras visavam à defesa da relação de trabalho, coibindo os excessos que se poderiam praticar, além de estabelecerem relações de colaboração, e não de conflito. O que estava em causa, então, não era a defesa de uma classe contra a outra, segundo um ideal paternalista, e sim a regulamentação de interesses comuns a uma determinada classe de profissionais.

Dispondo de mecanismos próprios para organizar as relações trabalhistas, as corporações prescindiam de qualquer outro instrumento jurídico. Além disso, o sistema produtivo, em geral, baseava-se, sobretudo, em trabalhos servis, que não justificavam a utilização do instrumento. Por essas razões, o contrato de trabalho, como

\footnotetext{
${ }^{22}$ MARTINEZ, Pedro Romano. Op. cit., p. 76-77.

${ }^{23}$ MANNRICH, Nelson. Inspeção do trabalho. São Paulo: LTr, 1991. p. 49.

24 Além dessas, é importante mencionar que, também no seio das corporações de ofício, surgiram as regras precursoras do atual regime de acidentes de trabalho e de segurança social, na medida em que as associações profissionais assumiam igualmente a função de mutualistas de seguros (Cf. MARTINEZ, Pedro Romano. Op. cit., p. 78-79).
} 
instrumento jurídico apto a regulamentar as relações individuais de trabalho, foi pouco utilizado na Idade Média.

Com o advento dos Descobrimentos e da abertura dos novos mercados, no século XVI, além das alterações ocorridas na sociedade, as corporações de ofício entraram em declínio na Europa, extinguindo-se no final do século XVIII, na maioria dos países. Dentre os motivos que ensejaram sua extinção, está o fato de que elas estavam preparadas apenas para o tipo de transação próprio das sociedades economicamente fechadas. Quando as relações de comércio se expandiram, as associações profissionais começaram a decair. A partir desse momento, de associações destinadas a regular as atividades de determinada classe profissional, as corporações de ofício passaram a ser vistas como entidades defensoras de privilégios e interesses de pequenos grupos. $\mathrm{Na}$ França, por exemplo, as disputas entre as corporações e o governo arrastaram-se por anos.

Já no século XVIII, o liberalismo político, econômico e jurídico, inspirado nos princípios consagrados pela Revolução Francesa, propagou a ideia da liberdade absoluta do homem na procura de seus próprios interesses, sem interferências do Estado e, consequentemente, de quaisquer associações. Imbuídos desses ideais, pensadores como Clicquot, Diderot e Turgot passaram a pugnar pela supressão de tais associações, acusando-as de serem causa de encarecimentos dos produtos, além de contrárias à ideia da liberdade para o trabalho. ${ }^{25}$ Antecedida por algumas tentativas frustradas de extinguir as corporações de ofício, ${ }^{26}$ em 1791, foi publicada, na França, a Lei Le Chapelier, que deu fim às associações, já consideradas, à época, clandestinas. ${ }^{27}$

De acordo com as conclusões da comissão constituída para estudar e resolver o problema das corporações de ofício, cujo relator era Issac René Guy Le Chapelier, tais associações impediam as livres convenções entre os particulares, fazendo concordar com contratos de adesão, em ameaça à ordem pública. Assim, a comissão

\footnotetext{
${ }^{25}$ NASCIMENTO, Amauri Mascaro. Contrato de Trabalho. São Paulo: LTr, 1970. p. 50.

${ }^{26} \mathrm{Na}$ França, a primeira tentativa de extinguir as corporações de ofício deu-se com um edito de 1776, inspirado em Turgot, no qual tais associações foram consideradas "instituições arbitrárias que não permitem ao indigente viver de seu trabalho." Mais tarde, o Decreto Dallarde, de 1790, determinou o desaparecimento de todas as corporações de ofício, considerando todo cidadão livre para o exercício da profissão ou ofício, depois de receber uma patente ou pagar um preço; contudo, mestres interessados em continuar dirigindo sua profissão organizaram nova resistência (Cf. NASCIMENTO, Amauri Mascaro. Op. cit., p. 50-51).

${ }^{27}$ Dispunha o artigo $7^{\circ}$ da referida lei: "A partir de $1^{\circ}$ de abril, todo homem é livre para dedicar-se ao trabalho, profissão, arte ou ofício que achar conveniente, porém estará obrigado prover-se de uma licença, a pagar impostos de acordo com as tarifas seguintes e a conformar-se com os regulamentos da polícia que existam que se expeçam no futuro" (Cf. BARROS, Alice Monteiro de. Curso de direito do trabalho. $5^{\mathrm{a}}$ ed., São Paulo: LTr, 2009. p. 61).
} 
concluiu que as corporações de ofício deveriam ser extintas, e, em seu lugar, deveria existir apenas o interesse particular de cada indivíduo para regular as relações de trabalho.

O Estado absolutista, por seu turno, considerava as associações como poderes intermediários entre o Estado e os cidadãos, sob o nome de um estado social ou profissão. A esse respeito, esclarece Pedro Romano Martinez:

Um poder autoritário e centralizado não pactua com a defesa do associativismo profissional em termos de liberdade e com poder negocial. Se as associações profissionais tiverem poder de negociação e capacidade para impor a sua vontade, contrariam as perspectivas de um poder centralizado. $^{28}$

Desse modo, a extinção das corporações de ofício, no final do século XVIII, fundamentou-se, sobretudo, na concepção de que qualquer agregação profissional contrariaria a liberdade de trabalho e o desenvolvimento tecnológico, difundindo-se na França a ideia de liberdade individual de trabalho, que, posteriormente, expandiu-se para os demais países. Conforme Júlio Manuel Vieira Gomes, houve o reconhecimento de que a liberdade e a igualdade formais poderiam configurar-se como instrumentos de domínio mais sofisticados e, em certo sentido, mais sutis e poderosos do que os tradicionais laços de servidão vigentes, por exemplo, na Idade Média. ${ }^{29}$

Assim, ainda que a origem histórica remota do contrato de trabalho seja anterior a esse período, fato é que, no período intermediário não se verificou a necessidade de instrumento jurídico específico para regular individualmente as relações de trabalho. No seio das corporações de ofício, como já mencionado, buscava-se a regulamentação de interesses comuns a uma determinada classe de profissionais, e não propriamente a proteção do trabalhador.

É com base nisso que Maria do Rosário Palma Ramalho afirma que, nesse período, a liberdade dos trabalhadores em geral tinha cunho relativo, comparável com situações de alienação parcial - temporariamente, ou mesmo com caráter de permanência, como ocorria na servidão da gleba -, e sujeição pessoal e continuada ao

\footnotetext{
${ }^{28}$ MARTINEZ, Pedro Romano. Op. cit., p. 80.

${ }^{29}$ GOMES, Júlio Manuel Vieira. Op. cit., p. 12.
} 
senhor das terras - nos casos dos servos domésticos e rurais -, além da dependência ampla e não restrita ao escopo do trabalho que caracterizavam a relação entre mestres e aprendizes. Tais razões, inclusive, reforçam sua conclusão no sentido de que a evolução do trabalho escravo para o trabalho livre foi uma evolução lenta e em diversos estágios, que evidenciou a diferença qualitativa entre o trabalho subordinado hodierno e seus antecedentes históricos. Segundo a autora, a origem do trabalho subordinado, como hoje concebido, é recente, identificando-se com a Revolução Industrial e a Revolução Francesa, sendo esta a principal responsável pela queda da concepção relativa do requisito da liberdade do prestador de serviços, dominante nas eras anteriores, por força da conjugação dos princípios de liberdade e igualdade entre os entes jurídicos privados, que tornaram inadmissíveis quaisquer vínculos de suserania ou outras privações e limitações da liberdade. $^{30}$

\subsection{Idade Moderna}

Na Idade Moderna, o pensamento filosófico consagrou a liberdade para o exercício das profissões, artes ou ofícios; aliado a ele, o advento das forças mecânicas, que substituíram a força muscular dos homens e dos animais, operou verdadeira revolução nos meios de produção e, sobretudo, nas relações entre capital e trabalho. Em decorrência de tais mudanças ou, mais propriamente, dos nefastos efeitos sobre a sociedade que delas advieram, o contrato de trabalho foi consagrado como instrumento capaz de mudar os rumos de História.

\subsubsection{Mudança de pensamento}

As teorias econômicas que precederam o liberalismo já tinham, por princípio, a valorização do trabalho, como um meio de produção, abordando a liberdade dos trabalhadores de contratar e dispor de seus frutos. O mercantilismo, por exemplo, formulou um conceito de riqueza essencialmente baseado na acumulação de metais

\footnotetext{
${ }^{30}$ Direito do trabalho - Parte I.... Op. cit., p. 48-49.
} 
preciosos, como ouro e prata; assim, indústria e comércio deveriam desenvolver-se para permitir o acúmulo desses metais. Para tanto, era imprescindível a liberdade de trabalho. ${ }^{31}$

Em 1750, surge a Escola Fisiocrática, cujos principais nomes foram Quesnay (1694-1774), Condillac (1715-1780), Gournay (1727-1759) e Turgot (17271781). Suas teorias eram contrárias ao excessivo protecionismo e à regulamentação detalhada e exaltavam o princípio de uma ordem natural e espontânea, segundo a qual todos, com base no direito natural, teriam direito de livremente trabalhar, produzir, bem como de usufruir dos rendimentos, materiais ou não, de seu trabalho. Os fisiocratas foram os criadores do tão propagado lema "laisser faire, laisser passer", 32 que influenciou o pensamento político e, mais tarde, o desencadeamento da questão social.

Contemporaneamente à Escola Fisiocrática, surge a Escola Clássica Liberal que, representada por Adam Smith (1723-1790), Malthus (1776-1834), Ricardo (1772-1823) e Stuart Mill (1806-1873), tomou o trabalho como atividade humana aplicada à produção, fonte de prosperidade geral.

Essas linhas provocaram mudança no pensamento econômico, motivadas, sobretudo, pela contribuição do pensamento liberal à questão social. Nesse aspecto, convém destacar que os ideais de liberdade de trabalho e de comércio propagados pelo liberalismo clássico foram determinantes para a afirmação da personalidade humana em todas as suas manifestações. Com isso, o homem foi liberto "dos vínculos do passado e do império opressivo da autoridade e da tradição". ${ }^{33}$

Segundo o pensamento liberal, a sociedade é fruto do consentimento entre os homens que viviam em estado de natureza. Nela, cada um, sob direção da vontade geral, vive em liberdade e igualdade, com a garantia de propriedade de tudo o que possui. Nesse cenário, o Estado apresenta-se como mero intermediário entre o povo e a vontade geral, fazendo-se porta-voz dessa, com o objetivo de garantir a liberdade civil e política.

No campo jurídico, o pensamento liberal influenciou decisivamente a codificação do direito civil, reunindo um conjunto de normas destinadas a garantir a liberdade civil do indivíduo em sua vida privada, dentro ou fora do Estado e das relações

\footnotetext{
${ }^{31}$ NASCIMENTO, Amauri Mascaro. Curso de direito do trabalho. $25^{\mathrm{a}}$ ed., São Paulo: Saraiva, 2010. p. 44-45.

${ }^{32}$ Segundo Alice de Barros Monteiro, a autoria do lema é atribuída a Vicent Gournay (Cf. BARROS, Alice Monteiro de. Op. cit., p. 62).

${ }^{33}$ NASCIMENTO, Amauri Mascaro. Curso de direito.... Op. cit., p. 48.
} 
de direito público. ${ }^{34}$ Por sua vez, as normas de direito civil exerceram expressiva influência sobre a disciplina inicial do contrato de trabalho. ${ }^{35}$

Naquele contexto, o contrato era visto como forma de criar, resolver e modificar as relações entre os indivíduos e os Estados e era símbolo de liberdade, o que repercutiu na forma pela qual viriam a ser conhecidas as relações entre empregado e empregador. Acreditava-se então que o desequilíbrio econômico e social das relações trabalhistas pudesse ser administrado pelos próprios interessados, por meio da autonomia privada das partes, mentalidade que se consolidou no período posterior à Revolução Industrial.

Mais tarde, sob a influência das Escolas Realistas, Dupont White (1807-1878), primeiro discípulo de Adam Smith, sensível à vida dos operários ingleses, passa a criticar o liberalismo puro e a defender o intervencionismo do Estado, do qual resultariam as normas do direito do trabalho.

\subsubsection{Mudanças no processo produtivo e no campo econômico}

Desde a publicação da Lei Le Chapelier, estava vedada qualquer forma de associação profissional, o que impedia os trabalhadores, livres para dispor de sua força de trabalho, de reunirem-se a fim de promover o intercâmbio de experiências e ideias, além da defesa da classe operária. Além disso, com a vitória da Revolução Francesa, desapareceram, no plano jurídico, as distinções e as desigualdades - embora permanecessem no plano fático. Como resultado, os trabalhadores ficaram sujeitos à "ditadura contratual dos patrões", ${ }^{36}$ na qual se estabeleciam, unilateralmente, as condições do contrato de trabalho a que eles deveriam sujeitar-se.

Predominou, no período, o regime de liberdade contratual, caracterizado pela inexistência de qualquer empecilho à livre estipulação das relações de

\footnotetext{
${ }^{34}$ NASCIMENTO, Amauri Mascaro. Curso de direito.... Op. cit., p. 49.

${ }^{35}$ No Código de Napoleão, de 1804, encontram-se as diretrizes da organização do trabalho nos quadros do Direito Civil. Atrelado às origens romanas, neste código, o contrato de trabalho vinha regulado como uma das modalidades da locação, por meio de somente dois artigos: o primeiro deles dispunha que o trabalhador somente poderia obrigar-se por certo tempo, ou para a execução de determinada obra; o segundo dispunha sobre os créditos atribuídos às afirmações do empregador, no tocante ao pagamento dos salários. Com efeito, pretendia-se, pela disposição do primeiro artigo, proibir o trabalho por toda a vida, evitando, assim, o reaparecimento da escravidão (Cf. BARROS, Alice Monteiro de. Op. cit., p. 62).

${ }^{36}$ ABRANTES, José João. Formação e evolução histórica do direito do trabalho. Direito do trabalho ensaios. Lisboa: 1995. p. 22.
} 
emprego, de forma que os homens que precisavam trabalhar ofereciam sua força de trabalho por qualquer preço e condição. ${ }^{37} \mathrm{Na}$ maioria dos casos, o acordo celebrado entre os trabalhadores e os detentores de capital era apenas aparente e, constrangidos pela necessidade ou pelo temor de um mal maior, os primeiros acabavam submetidos a toda ordem de excessos, tanto de natureza material, quanto de natureza moral.

Nessa nova estrutura social, os trabalhadores foram conduzidos a graves e inesperadas situações de miséria, que deram origem à chamada "questão social". 38 Passaram a ser considerados um dos fatores da produção, juntamente com a terra e o capital, com condições de trabalho sujeitas às regras gerais do mercado, notadamente, a lei da oferta e da procura. Percebeu-se que, em matéria contratual, o liberalismo transformava a desigualdade de fato em desigualdade jurídica, conforme exposto por Felice Battaglia:

[...] o liberalismo partia da liberdade, concebendo-a, porém, de maneira formal e individualista - complexo de direitos relativos ao indivíduo quando a punha em exercício, dissolvia-a na desigualdade - acabava, mesmo, por anular o próprio indivíduo na mais cega servidão. O operário, que tenha somente direitos, mas que não possua meios para os tutelar, na realidade, submete-se diante do empregador, que o tem à sua mercê, que o trata como coisa e como coisa dele dispõe. ${ }^{39}$

\footnotetext{
${ }^{37}$ NASCIMENTO, Amauri Mascaro. Contrato de trabalho. Op. cit., p. 14.

${ }^{38}$ Sobre a questão social, veja-se Amauri Mascaro Nascimento (Curso de direito.... Op. cit., p. 33): "Os efeitos do capitalismo e das condições da infraestrutura social se fizeram sentir com muita intensidade com a Revolução Industrial. Destaque-se o empobrecimento dos trabalhadores, inclusive dos artesãos, a insuficiência competitiva da indústria que florescia, os impactos sobre a agricultura, os novos métodos de produção em diversos países e as oscilações de mercado. A família viu-se atingida pela mobilização da mão de obra feminina e dos menores pelas fábricas. Os desníveis entre classes sociais se fizeram sentir de tal modo que o pensamento humano não relutou em afirmar a existência de uma séria perturbação ou problema social." Pedro Romano Martinez relata que da percepção de tais conflitos sociais, constitui-se a teoria marxista da luta de classes; prossegue sua análise afirmando que "[...] a degradação das condições de vida dos trabalhadores e suas famílias era uma realidade. Foi este panorama negro vivido na segunda metade do século XIX, prolongando-se, em alguns casos, pelo século XX, que veio a dar origem à chamada 'Questão Social"”. (Cf., Op. Cit., p. 83). Ainda sobre a situação dos trabalhadores nesse período, chega-se a afirmar que "Nem na antiga Roma os escravos, tratados como coisas, tiveram tratamento semelhante. O dono da 'coisa' tinha pelo menos o cuidado de evitar que se estragasse antes do tempo. Dava-lhe alimento e abrigo; curava-lhe as doenças. Na fase áurea do liberalismo, o simples pagamento do salário desobrigava o patrão de qualquer encargo dessa natureza. E o salário, então, mal dava para comer" (Cf. SAAD, Eduardo Gabriel. Consolidação das Leis do Trabalho comentada. 44a ed., São Paulo: LTr, 2011. p. 562).

${ }^{39}$ BATTAGLIA, Felice. Filosofia do trabalho. Trad. Luis Washington Vita e Antonio D'Elia. São Paulo: Saraiva, 1958. p. 325 Apud SILVA, Walküre Lopes Ribeiro da. Autonomia privada, ordem pública e flexibilização do direito do trabalho. In MEDEIROS, Antonio Paulo Cachapuz. Faculdade de Direito da PUCRS: O ensino jurídico no limiar do novo século - edição comemorativa do cinqüentenário (19471997). Porto Alegre: Edipucrs, 1997. p. 215.
} 
Ao contrário do que pretendia o liberalismo, a intervenção estatal passou a ser considerada elemento essencial de política social e, sem deixar de prestigiar a liberdade de trabalho, o contrato de trabalho foi eleito o instrumento capaz de mudar os rumos da História. Ilustra essa necessidade o texto da justificativa contida no relatório enviado à Assembleia Nacional Portuguesa sobre a Proposta de Lei no 1.952, de 10 de Março de 1937, primeiro diploma legal a definir o contrato de trabalho na legislação de Portugal:

As disposições da legislação vigente relativas ao regime jurídico do contrato de prestação de serviços são manifestamente insuficientes para dar satisfação a todos os conflitos que a complexidade sempre crescente das relações jurídicas e sociais entre quem presta e quem utiliza o trabalho suscita na esfera da actividade das diversas profissões.

Através da multiplicidade de aspectos que revestem hoje essas relações, frequentemente se observa não corresponderem as escassas normas reguladoras da matéria às necessidades da hora presente e achar-se a doutrina que as inspirou bastante distanciada dos novos princípios e conceitos de justiça social.

Por isso se apresenta esta proposta de lei, que, embora não aspire a fazer reforma completa da matéria, procura suprir as deficiências mais notadas na prática, e que só no esforço interpretativo do julgador encontravam remédio, e ao mesmo tempo dar actualidade e maior amplitude a regras legais de constante aplicação, de modo a proteger-se mais dignamente o dever social de trabalhador.

Havia, em primeiro lugar, que definir o conteúdo jurídico do contrato de trabalho, pois, embora a jurisprudência dos tribunais tivesse já estabelecido certas balizas, a incerteza e a instabilidade dos julgados não lhes permitiam fixação definitiva, além de que a natural tendência individualista do intérprete conduzia muitas vezes a soluções que, nem por se harmonizarem com a letra da lei escrita, acompanham as modernas aspirações do direito português do trabalho. ${ }^{40}$

\footnotetext{
${ }^{40}$ MATOS, Albertino de. Contratos de trabalho e previdência corporativa. Coimbra: Coimbra, 1937. p.
} 45 . 
Tornada a questão trabalhista jurídica, o Estado passou a intervir também nas relações de trabalho, estabelecendo como normas legais obrigações que antes poderiam ser livremente pactuadas entre as partes, de acordo com as circunstâncias e conveniências particulares. Por meio de patamares mínimos, ele buscou proteger os trabalhadores, antes de liberar a vontade dos contratantes. Essa foi a maneira encontrada pelo Estado para conciliar interesses distintos, como a liberdade dos particulares e o interesse público, e garantir condições de trabalho mínimas, abaixo das quais nenhum trabalhador poderia dispor de sua força de trabalho. ${ }^{41}$ Agindo assim, o próprio Estado reconheceu, no contrato de trabalho, a primeira garantia de liberdade e de proteção do trabalhador. $^{42}$

Devido às razões elencadas, afirma-se que, na Idade Moderna, a Revolução Industrial foi responsável pelo aperfeiçoamento da relação de trabalho livre e subordinado, objeto de regulação pelo contrato de trabalho. Tendo como núcleo a relação trabalhista, desenvolveu-se, a partir desse momento, um complexo de institutos, princípios e regras próprias, que deram origem a um novo ramo do direito, o direito do trabalho ${ }^{43}$, responsável pela dignificação da vida dos trabalhadores e pelo despertar da vocação humanitária e social do ordenamento jurídico.

No curso normal das relações sociais, a tipificação das relações trabalhistas pôs fim aos regimes de escravidão e de servidão, além de excluir outras formas de trabalho compulsório, nas quais o ser humano trabalha segundo interesses alheios à sua própria vontade. Com o contrato de trabalho, o homem assumiu o direito de dispor de seu próprio labor, conforme suas próprias necessidades, utilizando-o como moeda de troca para garantir o seu sustento e dignidade.

A consciência de que a liberdade apenas formal do trabalhador pode ser tanto ou mais cruel do que os regimes institucionalizados de exploração de trabalho tornou necessária a existência de um instrumento jurídico específico para restabelecer o equilíbrio entre as partes. Para tanto, foi preciso restringir a autonomia privada dos envolvidos e, no campo contratual, ao invés de prevalecerem cláusulas determinadas por ambos, a lei interferiu, impondo suas condições e garantindo padrões

\footnotetext{
${ }^{41}$ NASCIMENTO, Amauri Mascaro. Contrato de trabalho. Op. cit., p. 15-16.

${ }^{42}$ GOMES, Julio Manuel Vieira. Op. cit., p. 14.

${ }^{43}$ As problemáticas laborais criadas pela Revolução Industrial levaram à autonomização das regras de Direito do trabalho em relação ao Direito Civil na medida em que se tornou necessária a criação de uma legislação de proteção específica aos trabalhadores, inexistente no direito comum (Cf. ANTUNES, Carlos, PERDIGÃ̃O, Carlos. Relações laborais e direito do trabalho. Ano VI, n. 10, mar. 2007. p. 11-12).
} 
mínimos de comportamento, ainda que contrários à vontade do empregador e do empregado.

Essa foi a forma encontrada pelo direito do trabalho para solapar descompensações econômicas e contratuais e se, em princípio, a lei apenas interferiu e impôs limites, mais tarde, com o aprimoramento das relações de trabalho e, especialmente, das relações coletivas de trabalho, outras fontes de limitação surgiram, a exemplo das normas coletivas de trabalho.

A regularização abundante do contrato de trabalho foi tomada, por alguns autores, como a circunstância que o torna ainda mais "contratual", definindo-se sua natureza jurídica. A liberdade, característica dele, residiria no consentimento à constituição da relação trabalhista, e não na liberdade de determinação de seu conteúdo, à semelhança do que ocorre em outros tipos contratuais, como no de seguro, em que a autonomia privada das partes é tanto ou mais limitada do que a verificada no contrato de trabalho. ${ }^{44}$

Fala-se, nesse momento de transformação das relações sociais, na contratualização das relações de trabalho, ${ }^{45}$ as quais são revestidas por um modelo jurídico com características próprias. Mesmo com as limitações à autonomia das partes impostas pelas normas editadas pelo Estado ao longo do tempo, os ajustes contratuais no campo das relações trabalhistas trouxeram maior garantia de estabilidade e harmonia na vida social, uma vez que o contrato de trabalho acomoda diferentes prioridades: a valorização da remuneração, por parte dos empregados, e a busca pela redução de custos para maximização dos lucros, por parte dos empregadores. Conhecendo, de antemão, as obrigações e os deveres atribuídos a cada uma das partes na relação de trabalho, os indivíduos aproximam-se de um ideal de paz. Conforme preleciona Amauri Mascaro Nascimento, "a institucionalização do contrato de trabalho, portanto, permite uma nova e melhor colocação do problema das relações de trabalho". ${ }^{46}$

De todo o exposto até o momento, claro está que o contrato de trabalho consolidou-se como instrumento jurídico fundamental nas diversas legislações que objetivaram as relações de trabalho subordinado, consolidando-se como contrato específico, não equiparável aos demais tipos. Essa diferenciação deriva, em muito, dos

${ }^{44}$ CESARINO JUNIOR, Antonio Ferreira. Natureza jurídica do contrato individual de trabalho. Rio de Janeiro: A. Coelho Branco, 1938. p. 109-110.

${ }^{45}$ Não se quer sugerir, com isso, nenhum modelo contratual que subestime a lei; ao contrário, a lei trabalhista impõe-se de forma cogente e apenas quando permitir derrogação outras normas prevalecerão (Cf. NASCIMENTO, Amauri Mascaro. Curso de direito.... Op. cit., p. 540).

${ }^{46}$ Ibidem, p. 543. 
nefastos efeitos do individualismo ortodoxo que marcou o período pós-Revolução Industrial e justifica-se por uma óbvia e importante observação: o seu objeto não é uma mercadoria qualquer, e sim algo inerente ao próprio trabalhador.

Assim, pode-se afirmar que a instrumentalização do contrato de trabalho, a um só tempo, representou a tomada de consciência da grave questão social e desestimulou, na medida do possível, os antagonismos entre patrões e trabalhadores, servindo como amparo aos choques de interesses. 


\section{CONTRATO INDIVIDUAL DE TRABALHO: PRINCIPAIS ASPECTOS TEÓRICOS}

Com a contratualização das relações entre trabalhador e empregador, as relações trabalhistas multiplicaram-se em outras formas contemporâneas. A antiga concepção binária entre trabalho autônomo e trabalho subordinado foi substituída por uma divisão tridimensional, fundada na autonomia e na subordinação, isto é, trabalho para si ou trabalho para outro. Nessa esteira, desenvolve-se, ainda, o conceito da parassubordinação, de origem italiana, que versa sobre o trabalho com características híbridas de autonomia e subordinação, mas que não se enquadra em nenhuma área em específico, posto ser a coordenação seu principal elemento. Não obstante tais mudanças, o contrato de trabalho conservou-se como instrumento essencial do direito do trabalho contemporâneo, concretizando o regime jurídico de utilização do trabalho humano livre e subordinado, núcleo motor do processo produtivo próprio das sociedades capitalistas.

\subsection{Denominação}

Os autores pátrios discordam quanto ao início da utilização da expressão contrato de trabalho. Para Amauri Mascaro Nascimento, por exemplo, a expressão contrato individual de trabalho foi utilizada pela primeira vez em 1815, por Hubert-Valleroux, e depois por Fabreguettes, em 1896, como título de livro, substituindo a expressão locação de serviços. ${ }^{47}$ Por sua vez, Cesarino Junior afirma que a expressão contrato de trabalho foi utilizada pela primeira vez na França, pelo Decreto de 18 de julho de 1901, que garantia aos reservistas e territoriais, chamados sob as bandeiras para um período obrigatório de instrução militar, sua conservação no trabalho. Em comum, destacam o desapego à origem civilista, pois, como destacado por Cesarino Junior, a nova expressão era desconhecida dos antigos códigos, que incluíam o contrato de trabalho como modalidade de locação de serviços. ${ }^{48}$

\footnotetext{
${ }^{47}$ Contrato de trabalho. Op. Cit., p. 16.

${ }^{48}$ Nesse sentido, Cesarino Junior esclarece que alguns autores, como Planiol e Ripert, criticaram a denominação "contrato de trabalho", julgando mais apropriada a expressão "locação de trabalho" (Cf. Op. cit., p. 18).
} 
Contudo, diante da liberdade e independência dos trabalhadores, a noção civilista, em referência à locatio conductio operarum do direito romano, não mais se justificava. Mais do que isso, a preocupação com a pessoa do trabalhador como resultado da sujeição pessoal, fruto do estado de subordinação, tornou impossível submeter as relações trabalhistas às regras civilistas. Passou-se a utilizar, então, a expressão contrato de trabalho, a qual melhor conseguiria sintetizar, na sua generalidade, a fonte contratual do trabalho retribuído. ${ }^{49}$

Tal expressão, todavia, não passou imune a críticas. Em primeiro lugar, cite-se a crítica feita por Planiol, para quem "contrato de trabalho" não traduzia a natureza do instituto, indicando, ao revés, o objeto de sua prestação (trabalho) ${ }^{50}$ A esse respeito, Mauricio Godinho Delgado sustenta que, do ponto de vista sociojurídico, pode a denominação representar apenas o aspecto mais relevante do instituto ou o objeto a que se refere. Em ambas as hipóteses, ela significa o trabalho prestado por uma pessoa natural a outrem e cumpre sua principal missão, espelhar o conteúdo essencial da figura a ser definida. ${ }^{51}$

Além da crítica quanto à natureza do instituto, para Planiol, o termo trabalho abarcaria uma amplitude muito maior do que o efetivo conteúdo do contrato em exame, compreendendo não só a relação de emprego, mas outras, como a relação de trabalho autônomo ou eventual, que não possuem, tecnicamente, natureza empregatícia. Nesse sentido, a expressão "contrato de emprego" seria mais adequada. ${ }^{52}$

Embora a observação seja irreparável do ponto de vista técnico, a expressão "contrato de trabalho" foi consagrada pela doutrina juslaboralista em face da relevância, projeção e tendência expansionista da relação empregatícia, reduzindo espaço às demais relações de trabalho ou assimilando às suas normas situações fáticas

\footnotetext{
${ }^{49}$ A expressão "contrato de trabalho" foi consagrada pela legislação constitucional e social, antes mesmo da promulgação da Consolidação das Leis do Trabalho, em 1943: (i) Constituição de 1937 - Art. 61. São atribuições do Conselho da Economia Nacional: [...] c) editar normas reguladoras dos contratos coletivos de trabalho entre os sindicatos [...]; Art. 137. A legislação do trabalho observará, além de outros, os seguintes preceitos: a) os contratos coletivos de trabalho concluídos pelas associações [...]; b) os contratos coletivos de trabalho deverão estipular obrigatoriamente a sua duração [...]; g) nas empresas de trabalho contínuo, a mudança de proprietário não rescinde o contrato de trabalho [...]; e Art. 138. [...] estipular contratos coletivos de trabalho obrigatórios para todos os seus associados [...]; (ii) Lei $\mathrm{n}^{\circ}$ 62, de 1935 - Art. $5^{\circ}$. São causas justas para despedida: [...] j) força maior que impossibilite o empregado de manter o contrato de trabalho; Art. 16. Comprovado o inadimplemento do contrato de trabalho [...] (Cf. CESARINO JUNIOR, Antonio Ferreira. Op. cit., p. 65-66.).

${ }^{50}$ Para ilustrar tal crítica, Mauricio Godinho Delgado esclarece que seria o mesmo que denominar o contrato de locação imobiliária como "contrato de bem imóvel" (Cf. DELGADO, Mauricio Godinho. Contrato de Trabalho. Caracterização, distinções e efeitos. São Paulo: LTr, 1999. p. 18).

51 Ibidem, p. 18.

52 O uso da expressão "contrato de emprego" também é defendido por José Martins Catharino (Cf. Compêndio de Direito do trabalho. V. 1, São Paulo: Saraiva, 1981. p. 215 e ss.).
} 
originariamente não formuladas como tal. Firmou-se, na tradição jurídica, a tendência de designar-se a espécie mais importante - relação de emprego - pela denominação cabível ao gênero - relação de trabalho.

Nessa linha de raciocínio, a expressão "contrato de trabalho" pode ser tomada tanto no sentido estrito, em referência à relação empregatícia, regulada pela Consolidação das Leis do Trabalho, quanto no sentido lato, abarcando todos os contratos que tenham como objeto a pactuação de prestação de serviços de uma pessoa em favor de outra, tais como o contrato de empreitada, o contrato de prestação autônoma e de prestação eventual de serviços, além de outros contratos de prestação laboral distinta da relação empregatícia. No presente trabalho, a expressão será utilizada em referência à relação de emprego, no sentido específico.

Cesarino Junior distingue, ainda, o contrato individual de trabalho do contrato coletivo de trabalho: o contrato individual propriamente dito seria celebrado por um só indivíduo, podendo ser chamado "contrato singular", enquanto o contrato coletivo seria denominado por vários trabalhadores que não constituem uma pessoa jurídica, podendo ser chamado "contrato de equipe". ${ }^{53}$ Conforme o autor, portanto, a nota distintiva entre os dois tipos de contrato seria, tão somente, o número de empregados que ocupam um dos polos da relação contratual, entendimento que, atualmente, está em desacordo com a doutrina e a legislação vigentes.

Contudo, contrato individual e contrato coletivo de trabalho são instrumentos absolutamente distintos. A definição e caracterização do primeiro será objeto do tópico seguinte. Quanto ao contrato coletivo, embora seu estudo não esteja inserido no escopo deste trabalho, fazem-se necessários alguns apontamentos sobre suas características gerais.

Alguns autores pátrios utilizam a expressão "contrato coletivo de trabalho" como sinônimo das expressões que designam os dois instrumentos coletivos reconhecidos pela legislação trabalhista brasileira, a convenção e o acordo coletivo de trabalho. Todavia, tais expressões referem-se, na prática, a instrumentos jurídicos distintos.

\footnotetext{
53 Quanto ao tema, Cesarino Junior cita a definição do espanhol Gallart Folch, para quem "contrato individual é aquele pelo qual um operário contrata seu trabalho com um patrão, seja este uma pessoa física ou moral (...) contrato de equipe é aquele no qual o sujeito operário do contrato é um grupo de trabalhadores organizados espontânea e exclusivamente para realizar um trabalho em comum” (Op. cit., p. 67-68).
} 
Consoante definição do artigo 611, da Consolidação das Leis do Trabalho, ${ }^{54}$ a convenção coletiva de trabalho é o instrumento normativo por meio do qual dois ou mais sindicatos, representativos de categorias econômicas e profissionais, estipulam condições de trabalho aplicáveis aos contratos individuais de trabalho, no âmbito das respectivas representações. Na maior parte dos casos, ela tem aplicação restrita a determinado município, estado da Federação ou região inferior ao território nacional.

Geralmente, a negociação coletiva ocorre entre as bases de representação dos empregados e empregadores, ou seja, os sindicatos. Na falta deles, as federações e, em último caso, as confederações representativas das categorias profissionais e econômicas estão legitimadas para celebrar convenção coletiva de trabalho para reger as relações das categorias a elas vinculadas. ${ }^{55}$

$\mathrm{O}$ acordo coletivo de trabalho, definido no $\S 1^{\circ}$, do mencionado artigo $611^{56}$, é definido como o instrumento normativo celebrado entre os sindicatos representativos da categoria profissional e uma ou mais empresas da correspondente categoria econômica, estipulando condições de trabalho aplicáveis no âmbito da(s) empresa(s) acordante(s). As disposições do acordo coletivo de trabalho têm aplicação ainda mais restrita do que as da convenção coletiva de trabalho, pois é restrita às relações de individuais de trabalho mantidas com a(s) empresa(s) que firma(m) o acordo com o sindicato profissional.

Já o contrato coletivo de trabalho é observado somente no direito estrangeiro e, segundo perspectiva simplista da questão, compreende uma negociação coletiva em âmbito nacional. ${ }^{57}$ No sistema jurídico brasileiro, não há regulamentação específica desse instituto jurídico. 54 Art. 611, CLT - Convenção Coletiva de Trabalho é acordo de caráter normativo, pelo qual dois ou mais
sindicatos representativos de categorias econômicas e profissionais, estipulam condições de trabalho
aplicáveis, no âmbito das respectivas representações, às relações individuais de trabalho.
${ }_{5}$ Nesse sentido, estabelece o artigo 857 , parágrafo único, da Consolidação das Leis do Trabalho, in verbis:
"Quando não houver sindicato representativo da categoria econômica ou profissional, poderá a representação
ser instaurada pelas federações correspondentes e, na falta destas, pelas confederações respectivas, no âmbito
de sua representação".
56 Art. $611, \$ 1^{\circ}$, CLT - É facultado aos Sindicatos representativos de categorias profissionais celebrar
Acordos Coletivos com uma ou mais emprêsas da correspondente categoria econômica, que estipulem
condições de trabalho, aplicáveis no âmbito da emprêsa ou das acordantes respectivas relações de trabalho.
57 O estudo aprofundado da contratação coletiva na legislação italiana, por exemplo, aponta para a existência
de contratos coletivos em diversos níveis, correspondentes, respectivamente, aos vários níveis de organização
sindical naquele país, assim classificáveis: i) acordos interconfederais - correspondem aos grandes acordos
nacionais, que se relacionam às grandes massas de trabalhadores independentemente do setor de produção ao
qual se relacionam; ii) contratos coletivos nacionais de categoria - corresponde ao contrato coletivo
propriamente dito; e iii) contratos provinciais ou empresariais - correspondem aos contratos coletivos
celebrados para resolver problemas locais ou setoriais, no âmbito de determinado território; podem servir de
recurso aos contratos coletivos nacionais (contratos coletivos propriamente ditos) para especificar 


\subsection{Definição}

A figura do contrato de trabalho só veio a ser definida pela legislação brasileira no artigo 442, do Decreto $\mathrm{n}^{\circ} 5.452$, de $1^{\circ}$ de Maio de 1943 , que aprovou a Consolidação das Leis do Trabalho como sendo "o acordo tácito ou expresso, correspondente à relação de emprego." A redação desse artigo foi bastante questionada pela doutrina, especialmente por resultar em um verdadeiro círculo vicioso de afirmações entre contrato-relação de emprego, relação de emprego-contrato. ${ }^{58}$

Para Octavio Bueno Magano, o prejuízo à melhor técnica jurídica foi resultado de um "acordo teórico" entre as correntes contratualista e anticontratualista, no momento da elaboração do texto consolidado. Isso porque, ao mesmo tempo em que o texto legal buscou reverenciar a noção de contrato, defendida pela teoria contratualista, buscou reverenciar, também, a noção de relação de emprego, defendida pela teoria anticontratualista. ${ }^{59}$

Arnaldo Süssekind entendeu que, ao introduzir o conceito de relação de emprego conjugado com o de contrato de trabalho, o legislador apenas pretendeu despojar o contrato de trabalho das formalidades impostas quando da celebração dos negócios jurídicos, e não da sua contratualidade. Com isso, manteve-se o elemento vontade na formação do vínculo jurídico, sem, contudo, excluir da proteção do direito do trabalho as situações fáticas não antecedidas pela etapa contratual, como demonstra a adoção da teoria do contrato-realidade.

As diversas opiniões em torno do conceito legal refletiram, na realidade, a ausência de unanimidade quanto à natureza jurídica da relação entre o empregado e o empregador, se contratual ou não, entre os próprios membros da Comissão que elaborou o texto consolidado, como se infere da própria exposição de motivos, assinada por Alexandre Marcondes Filho:

determinada matéria ou para um mais completo tratamento de determinado instituto (Cf. MAGALHÃES, Daniel de Castro. Contratos coletivos de trabalho no sistema jurídico italiano: derrogabilidade/inderrogabilidade e flexibilização. In Revista do Tribunal Superior do Trabalho, Brasília, Vol. 72, n. 2, maio/ago, 2006. p. 104).

${ }^{58}$ MARANHÃO, Délio. Direito do trabalho, Fundação Getúlio Vargas, 1987. p. 36.

${ }^{59}$ Manual de direito do trabalho. V. II, $4^{\text {a }}$ ed., São Paulo: LTr, 1993. p. 25. 
[...] 42. A clara e total definição que do contrato individual do trabalho foi dada pelo anteprojeto da Consolidação- provocou algumas divergências de mero gosto polêmico.

43. A emenda então apresentada não pôde ser aceita. Revelava, primeiramente, incompreensão do espírito institucional tantas vezes salientado nesses empreendimentos. Repetia ainda um conceito prévio e básico já formulado, qual seja, o de empregado.

44. O que os objetantes não alcançaram foi o deliberado propósito de se reconhecer a correspondência e equivalência entre a "relação de emprego" e o "contrato individual do trabalho", para os efeitos da legislação social, correspondência essa que a escola contratualista italiana nega, exigindo a expressa pactuação.

45. Na concepção do projeto, admitido, como fundamento de contrato, o acordo tácito, é lógico que a "relação de emprego" constitui o ato jurídico suficiente para provocar a objetivação das medidas tutelares que se contêm no direito do trabalho em vigor.

46. O conceito firmado na Consolidação é tanto mais justo e relevante quanto é o que se evidencia em face de contratos formalmente nulos ou substancialmente contrários à ordem pública dos preceitos da legislação de proteção ao trabalho.

A deficiência do texto legal foi suprida pela definição de um conceito doutrinário, a partir dos elementos essenciais da relação de emprego - tomada como sinônima de contrato de trabalho - e do nexo que os mantém integrados. Amauri Mascaro Nascimento, por exemplo, definiu o contrato de trabalho como sendo o "negócio jurídico expresso ou tácito, mediante o qual uma pessoa natural obriga-se perante pessoa natural, jurídica ou ente despersonificado, a uma prestação pessoal, não eventual, subordinada e onerosa de serviços". ${ }^{60}$

Tecnicamente, a parte final dessa definição retrata os cinco elementos essenciais que caracterizam a relação de emprego, cuja concretização é viabilizada pelo contrato de trabalho, ${ }^{61}$ quais sejam: trabalho prestado por pessoa natural, pessoalidade, não-eventualidade, onerosidade e subordinação. Porém, tal diferenciação depende da visão do operador do direito quanto à coincidência ou não da relação de

${ }^{60}$ Contrato de trabalho..., Op. cit., p. 16-19.

${ }^{61}$ DELGADO, Mauricio Godinho, Op. cit., p. 516. 
emprego com o contrato de trabalho, pois, enquanto para alguns o contrato de trabalho constitui o fato gerador da relação de emprego, para outros, tanto o contrato, como a relação de emprego em si, podem originar o vínculo que o ordenamento jurídico objetiva regular e proteger. Assim, enquanto o contrato de trabalho resulta de condições pactuadas entre os sujeitos, a relação de emprego nasce, não por força da vontade das partes, mas de um fato, consubstanciado na prestação subordinada de serviços.

De qualquer forma, considerando-se que todo contrato corresponde a uma relação jurídica, ainda que não iniciada, as expressões contrato de trabalho e relação de emprego podem ser utilizadas com o mesmo sentido, entendimento este que será adotado no presente estudo. Conforme o entendimento de Antonio Lamarca:

[...] Uma relação qualquer entre duas pessoas passa a ser jurídica desde que relevante para o direito. $\mathrm{O}$ contrato de trabalho, mesmo que não iniciado, já se apresenta como relação jurídica, porque, como vimos, gera consequências de ordem patrimonial para ambas as partes; então, a relação decorrente desse contrato é uma relação jurídica de trabalho; logo, relação (jurídica) de trabalho e contrato de trabalho são a mesma coisa. Alguns procuram distinguir a relação de emprego do contrato de trabalho: aquela se realizaria com a efetiva incrustação na empresa e seria, assim, posterior ao contrato propriamente dito. Isto porque a Consolidação das Leis do Trabalho, no artigo 442 declara que o "contrato individual de trabalho é o acôrdo tácito ou expresso correspondente à relação de emprego"; mas essa definição é tautológica, porque relação de emprego e contrato individual de trabalho são a mesma coisa. ${ }^{62}$

\subsection{Natureza jurídica}

Como se viu, o conceito de contrato de trabalho inscrito no artigo 442, da Consolidação das Leis do Trabalho, dividiu a doutrina quanto à sua natureza jurídica. Se houve um acordo teórico entre os defensores das teorias contratualistas e anticontratualistas, ou se apenas foi intenção do legislador despojar referido ajuste das formalidades geralmente impostas quando da celebração dos negócios jurídicos em geral,

${ }^{62}$ Contrato individual de trabalho. São Paulo: Revista dos Tribunais, 1969. p. 96. 
fato é que, entre os doutrinadores pátrios, prevalece o entendimento quanto à natureza contratual do ajuste entre empregado e empregador.

O estudo sobre referidas teorias é dos mais interessantes, razão pela qual se passa a expor, ainda que em breves linhas, os fundamentos de cada uma delas.

O esforço dos contratualistas para incluir a relação de emprego no âmbito do direito civil é contemporâneo ao pensamento liberal e à supremacia do individualismo, os quais tomavam o contrato como expressão máxima da autonomia da vontade. O trabalho por conta alheia, assalariado sob a forma de emprego, foi incluído pelos juristas do século XVIII como um contrato semelhante aos demais contratos encontrados no direito civil. Como o poder da tradição obrigava escritores e mestres a manterem a doutrina, as posições sustentadas não fugiam ao esquema clássico, apenas alterando, de tempos em tempos, o paradigma contratual utilizado para explicar a vinculação na relação de trabalho subordinado, como arrendamento, compra e venda, sociedade e mandato.

A primeira das teorias contratualistas origina-se do direito romano, segundo o qual o contrato de trabalho era considerado como espécie de locatio. Assim, o contrato de trabalho nada mais seria do que uma manifestação do arrendamento: alugavase um homem ou sua força de trabalho como quem aluga um objeto.Tal concepção decorre da estrutura jurídica daquela sociedade, na qual o trabalhador era equiparado a um escravo e, em virtude disso, não poderia figurar como sujeito de uma relação jurídica, uma vez que era considerado um instrumento de trabalho. ${ }^{63}$

Essa concepção ultrapassou séculos, tanto que o Código Civil francês de 1804 ("Código Civil de Napoleão") regulou o contrato de trabalho no Título VIII, do Livro III, sob a rubrica "Do contrato de arrendamento". Corroborando esse entendimento, os autores da época estudavam o contrato de trabalho no capítulo que tratavam do arrendamento das coisas em geral. ${ }^{64}$ Contudo, especialmente por desconsiderar aspectos humanos e morais envolvidos na relação de trabalho, referido entendimento foi objeto de muitas críticas.

\footnotetext{
${ }^{63}$ NASCIMENTO, Amauri Mascaro. Curso de direito..., Op. cit., p. 572.

${ }^{64}$ Nesse sentido, Planiol escreveu: "Este contrato é um arrendamento, segundo o demonstra rápida análise: a coisa arrendada é a força de trabalho que reside em cada pessoa ou que pode ser utilizada por outra como a de uma máquina ou a de um cavalo; dita força pode ser dada em arredamento e é precisamente o que ocorre quando a remuneração do trabalho por meio do salário é proporcional ao tempo, da mesma maneira que ocorre com o arrendamento de coisa" (Cf. Traité élémentaire de droit civil, 1907 Apud NASCIMENTO, Amauri Mascaro. Curso de direito..., Op. cit., p. 574).
} 
Superada a fase inicial, o liberalismo econômico do século XVIII consolidou a ideia do contrato de trabalho como espécie de contrato de compra e venda, por meio do qual o empregado vende sua força de trabalho e, por essa transação, recebe um valor, como sua remuneração. ${ }^{65}$ Entretanto, para os opositores dessa teoria, ela não encontrava fundamento à luz do progresso social experimentado pela sociedade.

De fato, o trabalho não poderia ser considerado como mercadoria por razões de ordem lógica e filosófica. Como atividade passível de produzir por si própria, o trabalho materializa-se no objeto que produz ou transforma, mas não pode materializarse por si próprio; além disso, o trabalho é inerente à personalidade do ser humano, de forma que, através dele, o homem harmoniza-se com a natureza, transmitindo-lhe o sopro de sua inteligência. ${ }^{66}$

Para outros autores, o contrato de trabalho corresponderia a um contrato de associação, já que empregados e empregadores estariam unidos por uma finalidade comum: a produção de riquezas. ${ }^{67}$ Há, nessa teoria, um exagero de conceitos. Embora seja evidente que o sistema, por si, fomente uma relação de colaboração entre os sujeitos da relação contratual, com suposta comunhão de objetivos, há outros elementos da relação de emprego e, consequentemente, envolvidos no contrato de trabalho, que ao contrário, desfazem o aspecto de associação, a exemplo da subordinação do empregado em relação a seu empregador.

Houve, ainda, autores que equipararam o contrato de trabalho ao contrato de associação, em face da evidente união entre capital e trabalho. Todavia, como

\footnotetext{
${ }^{65}$ Sobre tal concepção, destaque-se o entendimento de Carnelutti, citado por Amauri Mascaro Nascimento. Inicialmente, Carnelutti tentar assimilar a prestação de trabalho e a de energia elétrica, ambas constituindo-se em forças que podem ser objeto de compra e venda; nesse sentido, o objeto do contrato de trabalho seria, pois, a energia psicofísica do trabalhador, que dele se desprende com o exercício da atividade, não retornando, como energia elétrica, à fonte da qual emanou. Em estudo posterior, entretanto, Carnelutti modifica seu ponto de vista, deslocando o objeto do contrato de trabalho da energia fornecida pelo trabalhador para o próprio trabalhador; essa mudança não significa, pois, um retorno à antiga concepção civilista do contrato de trabalho como contrato de arrendamento e de locação do próprio ser humano, e sim uma nova colocação desenvolvida pelos pensadores, que atribuem ao contrato de trabalho uma natureza especial e sui generis (Cf. Studi sulle energie como oggetto di rapporti giuridici, 1913 Apud NASCIMENTO, Amauri Mascaro. Curso de direito..., Op. cit., p. 577-578).

${ }^{66}$ LIMA, Adolpho. O contrato de trabalho. Lisboa, 1909 Apud NASCIMENTO, Amauri Mascaro. Curso de direito.... Op. cit., p. 579-580.

${ }^{67}$ Partidário dessa teoria, Chatelain defende que o fim lucrativo é elemento identificador entre os dois contratos (de trabalho e de associação); o salário seria um benefício do empregado, tais quais os benefícios do empregador; não seria, portanto, um preço qualquer que se paga ao trabalhador em troca de seus serviços, mas uma verdadeira parte do produto e produção. Ocorre que, ao invés de sua parte no preço incerto pelo qual o produto será vendido, os trabalhadores prefeririam uma parte menor, mas fixa e garantida (Cf. De la nature du contrat entre ouvriers et entrepreneurs. Paris, 1902 Apud NASCIMENTO, Amauri Mascaro. Curso de Direito.... Op. cit., p. 581).
} 
recorda Amauri Mascaro Nascimento, foram muitos os juristas que responderam negativamente a essa teoria, com base na própria sistemática da relação de emprego, contraposta à da sociedade. Na sociedade, todos os sócios recebem lucros, já no âmbito do contrato de trabalho, regra geral, o empregado recebe apenas salário, em quantia e periodicidade fixas; na sociedade, os sócios participam da formação da vontade social, enquanto o contrato de trabalho normalmente é formado unilateralmente, a partir da vontade e do poder empresarial pelo empregador; na sociedade, todos os sujeitos suportam os riscos do empreendimento econômico, no contrato de trabalho, não, exceto remotamente ou por condição especial prevista em lei, como nos casos de força maior. Entre os sujeitos da sociedade, há uma relação de igualdade, ao passo que, no contrato de trabalho, há subordinação; na sociedade, o animus que vivifica a atuação dos sujeitos é a affectio societatis, no contrato de trabalho, o animus contrahendi. Enquanto no relacionamento entre empregado e empregador há uma posição jurídica de credor e devedor, os sócios de uma sociedade não são, entre si, credores e devedores, mas todos os sócios são credores ou devedores conjuntos dela. Por fim, no contrato de trabalho, os empregados cedem sua força de trabalho - parte que lhes corresponde no produto - em troca de um salário e os sócios nada cedem em face de suas atividades societárias, apenas auferem lucros como remuneração do capital. ${ }^{68}$

Ainda seguindo a linha contratualista, alguns autores equipararam o contrato de trabalho ao mandato. ${ }^{69}$ Tal conclusão deriva da crítica à teoria do contrato de trabalho como arrendamento: enquanto no arrendamento está presente o elemento preço, no contrato de trabalho, está presente o elemento salário, de sorte que, na falta desse, o contrato de trabalho passa a ser considerado como mandato. Todavia, também essa concepção não foi unanimidade aceita, sob o principal argumento de inexistir, no contrato de trabalho, o elemento da representação, considerado essencial no mandato. ${ }^{70}$

Em sentido contrário, as teorias anticontratualistas procuraram fundamentar a relação jurídica trabalhista fora dos quadros do direito Civil e do contratualismo. Resultam das modificações pelas quais passou o pensamento humano após o liberalismo filosófico e, especialmente, após a grave questão social desencadeada pela

\footnotetext{
${ }^{68}$ Curso de direito.... Op. cit., p. 582.

${ }^{69}$ A teoria do contrato de trabalho como mandato desenvolveu-se na França e foi acolhida pelo legislador mexicano de 1870 (Cf. NASCIMENTO, Amauri Mascaro. Curso de direito.... Op. cit., p. 585).

${ }^{70}$ No mandato, o mandante é substituído/representado pelo mandatário; no contrato de trabalho não há a substituição/representação do empregador pelo empregado, salvo nos cargos de confiança (Cf. NASCIMENTO, Amauri Mascaro. Curso de direito.... Op. cit., p. 586).
} 
Revolução Industrial. São fundamentadas no intervencionismo estatal, que modificou a estrutura política, e na proscrição da economia liberal, com suas concepções de trabalho como mercadoria e salário como preço.

De acordo com as teorias anticontratualistas, o vínculo entre empregado e empregador não tem natureza de contrato, pois não há acordo de vontades. O fato de o empregado começar a prestar serviços seria suficiente para precisar o início de uma relação de emprego e desencadear a projeção dos efeitos previstos nas normas jurídicas. Além disso, a determinação das condições de trabalho, antes atribuída à vontade das partes, por meio do contrato, seria feita pelas normas coletivas, leis e regulamentos. Tais teorias foram adotadas pelas doutrinas então vigentes na Itália fascista e na Alemanha nazista, segundo as quais não havia igualdade entre os sujeitos da relação de emprego, mas hierarquia, sendo ela regulada não pelo contrato, mas pelo estatuto.

As teorias anticontratualistas sobre as relações de trabalho foram inspiradas na teoria das relações de trabalho fáticas, desenvolvida pelo autor alemão Heins Potthoff, no início do século XX, a qual visava a uma nova regulamentação da legislação contratualista em preparação na Alemanha, naquele período. Destaque-se que as teorias jurídico-sociais da relação de emprego e a forte coletivização marcaram o direito do trabalho alemão, durante a República de Weimar. ${ }^{71}$

Já no século XIX, doutrina e jurisprudência alemãs entendiam de forma unânime que não seria necessário um contrato com todos os requisitos de validade do direito civil para a formação de uma relação de emprego. Justificavam seu entendimento pela adoção de um conceito social de relação de emprego, o qual não admitia prejuízos aos empregados em razão de eventuais nulidades do contrato de trabalho. $\mathrm{O}$ caráter social da relação de emprego deveria se apresentar em primeiro plano, tendo menor importância o contrato individual.

Àquela época, Heins Potthoff estimava que 1/15, no máximo, das prestações de serviço, ainda fossem reguladas por contrato de trabalho. A partir dessa estimativa, concluiu que o contrato de trabalho formal já não tinha grande relevância para a realidade jurídica e social, razão pela qual a legislação trabalhista deveria preocupar-se com a regulamentação da relação de emprego fática entre dois cidadãos. Com isso,

\footnotetext{
${ }^{71}$ HIRATA, Alessandro. Relações contratuais fáticas. Tese apresentada para Concurso para Professor Titular junto ao Departamento de Direito Civil da Faculdade de Direito da Universidade de São Paulo, 2011. p. 23 e ss..
} 
Potthoff não pretendeu eliminar o contrato de trabalho, mas apenas diminuir sua importância, na medida em que o ajuste contratual continuava sendo o fundamento corriqueiro das relações de trabalho.

A admissão de uma relação de trabalho sem a correspondente formalização de contrato de trabalho expôs uma mudança estrutural no direito do trabalho, no sentido de diminuir a importância do instrumento jurídico. Admitiu-se, por meio da nova teoria, uma dualidade na formação da relação de trabalho: negócio jurídico e elementos meramente fáticos, paralelamente. ${ }^{72}$

Com efeito, entendeu-se que o direito das obrigações, cujo fim é a regulamentação das transferências patrimoniais, não se prestava a reger uma relação jurídica na qual o vértice recai sobre o ser humano, e não sobre uma coisa qualquer. Além disso, considerou-se a possibilidade de trabalho imposto autoritariamente, ao qual não se poderiam negar os efeitos da ordem jurídica, por não se verificar o consentimento de uma das partes. Em vista de atos cotidianos, com indiscutíveis reflexos na órbita jurídica, era necessário, portanto, que o direito apresentasse novas soluções.

A partir do direito alemão, o anticontratualismo alcançou posteriormente diversos outros países e diversas áreas do conhecimento jurídico. No direito do trabalho, por exemplo, foram formuladas duas teorias específicas sobre a formação de vínculo de trabalho sem a conclusão formal de um contrato: a teoria de relação de trabalho e a teoria do institucionalismo.

Pela teoria da relação de trabalho ou da relação de emprego, os autores negam ou minimizam ${ }^{73}$ a importância da vontade na constituição e no desenvolvimento do contrato de trabalho, daí a negativa do aspecto contratual. Para eles, basta a prática de atos de emprego no mundo físico e natural para atrair todos os efeitos previstos na ordem jurídica sobre os sujeitos da relação de emprego, substituindo-se, assim, a ideia do ajuste ou acordo entre as partes, pela ideia de inserção, engajamento ou

\footnotetext{
${ }^{72}$ Mais radical, Siebert desenvolveu a "teoria da integração do direito do trabalho", por meio da qual o autor pretendia afastar completamente o aperfeiçoamento de um contrato como fundamento da formação da relação de trabalho. Para ele, o único elemento necessário para a formação da relação de trabalho seria a integração do indivíduo na comunidade (no caso, a empresa). Com isso, afasta-se do dualismo na formação dos contratos admitido por Heins Potthoff (Cf. HIRATA, Alessandro. Op. cit., p. 25 e 26).

${ }^{73}$ Entre os autores que não negam, mas minimizam a importância da manifestação de vontade, está Mario de La Cueva, para quem a "concorrência da vontade do trabalhador é necessária para a relação de trabalho, porque ninguém poderá ser obrigado a prestar trabalhos pessoais sem o seu pleno consentimento". (Cf. Derecho mexicano del trabajo. Porrúa, 1963 Apud NASCIMENTO, Amauri Mascaro. Curso de direito.... Op. cit., p. 591-592).
} 
ocupação de trabalhador pela empresa e defendendo-se a formação de uma relação jurídica trabalhista como um fato objetivo, abstraído dos aspectos subjetivos da vontade humana. ${ }^{74}$ Entre os adeptos dessa vertente, destaca-se o jurista espanhol Alfredo Montoya Melgar. ${ }^{75}$ Com sua teoria das relações trabalhistas de fato, ele destaca a existência de relações trabalhistas originadas da mera incorporação do trabalhador na empresa, independentemente da celebração prévia de qualquer tipo de contrato.

Já pela teoria do institucionalismo, a empresa foi equiparada a uma instituição, cuja concepção como obra ou empreendimento que se realiza e dura juridicamente em um grupo social, como entidade que se estabelece pela harmonia ou correspondência de fatores subjetivos e objetivos, fundamenta a transubstanciação de um estado de fato - a relação de trabalho - em um estado de direito - o contrato de trabalho. ${ }^{76}$ A empresa seria, pois, a instituição que reúne empregado e empregador. O pressuposto dessa união não estaria na autonomia da vontade contratual, mas sim nas razões imanentes ao grupo, ao estado social objetivo, perpetuado e durável, ao qual os indivíduos se vinculam. Os empregados ficam sujeitos a condições de trabalho previamente estabelecidas por um complexo normativo constituído pela lei, normas coletivas e regulamentos de empresa.

Porém, tal concepção fica sem fundamento quando se tem em mente que o conceito de instituição não exclui o de contrato de trabalho. Não se nega que o estabelecimento patronal seja provido de um estatuto imperativo, sem o qual não pode funcionar, entretanto, o direito da instituição é independente do direito do contrato, que lhe é, em certo sentido, anterior. Isso significa que, desde a abertura de um estabelecimento, certas disposições, tais como regras sobre duração do trabalho, higiene e segurança no trabalho, a ele se aplicam, de maneira que a formação de nova relação individual de trabalho não modifica o estatuto preexistente. Na verdade, o contrato de trabalho insere o trabalhador na sociedade profissional, apenas completando as regras resultantes do direito da instituição. ${ }^{77}$

\footnotetext{
${ }^{74}$ NASCIMENTO, Amauri Mascaro. Curso de direito.... Op. cit., p. 588.

${ }^{75}$ Derecho del trabajo. $2^{\text {a }}$ Ed., Madrid: Tecnos, 1978.

${ }^{76}$ Segundo Recaséns Siches, "a instituição pertence ao direito sob dois pontos de vista: primeiro, porque a transformação das situações de fato em situações de direito se produz nela e por ela; segundo, porque é a fonte de direito; e, ademais, pelo que se refere à instituição-grupo, é a fonte de um direito autônomo interno (estatutário, corporativo ou institucional)" (Cf. Panorama del pensamiento jurídico en el siglo XX. Porrúa, 1963 Apud NASCIMENTO, Amauri Mascaro. Curso de direito.... Op. cit., p. 591).

${ }^{77}$ DURAND, Paul; JAUSSAUD, Robert. Traité de droit du travail. v. 1, Paris: Dalloz, 1947. p. 415 e ss. Apud NASCIMENTO, Amauri Mascaro. Curso de direito.... Op. cit., p. 592-593.
} 
Destaque-se que as teorias anticontratualistas foram duramente rebatidas pela doutrina, especialmente em virtude de sua origem totalitária. Para Antônio Lamarca, por exemplo, a origem totalitária delas é apontada como fator de preocupação, especialmente pela possibilidade de supressão de direitos trabalhistas pela manifestação de vontade unilateral do empregador. ${ }^{78} \mathrm{Na}$ mesma linha de raciocínio, Mauricio Godinho Delgado conclui que, ao enfatizar a estreiteza (real) da vontade e liberdade individuais obreiras no interior da relação de emprego, referidas teorias partem de um dado efetivo da realidade empírica, mas para alcançar uma conclusão teórica equivocada e uma proposição política sumamente conservadora e autoritária. ${ }^{79}$

No caso do ordenamento jurídico brasileiro, mencionado por ocasião da apresentação do conceito de contrato de trabalho inscrito no artigo 442, da Consolidação das Leis do Trabalho, os legisladores não manifestaram formalmente a adoção por nenhuma das teorias. Em face do conceito apresentado, como já relatado, a doutrina divergiu quanto a ter ocorrido um acordo teórico entre os defensores das teorias contratualistas e anticontratualistas ou, simplesmente, sobre ter intencionado o legislador somente despojar o contrato de trabalho das formalidades normalmente exigidas quando da celebração dos negócios jurídicos em geral. De todo modo, conclui-se que, tendo o legislador trabalhista pátrio tomado o contrato de trabalho como negócio jurídico, para cuja formação é indispensável o acordo de vontades entre as partes, não ignorou o vínculo jurídico surgido a partir de um evento prático.

Assim, não obstante a resistência inicial por parte da doutrina majoritária em relação às ideias anticontratualistas, estas encontraram grande receptividade no âmbito do direito do trabalho, movido pelos ideais de proteção à dignidade da pessoa humana, como demonstra a adoção da teoria do contrato-realidade. ${ }^{80}$ Cumpre destacar que

\footnotetext{
${ }^{78}$ Op. cit., p. 95.

${ }^{79}$ Curso de direito.... Op. cit., p. 320.

${ }^{80}$ No âmbito do Direito Civil, a teoria das relações contratuais fáticas foi apresentada por Günter Haupt, em 1941, na Alemanha. Com ela, o autor alemão defendeu que as relações contratuais poderiam ser estabelecidas por meio da simples efetivação de elementos fáticos, não sendo necessária a tradicional troca de declarações de vontade. Todavia, autores mais conservadores resistiram às novas idéias quanto à formação dos contratos, interpretando a teoria anticontratualista - no caso, representada pela teoria das relações contratuais fáticas como mera evolução da teoria dos negócios jurídicos - a qual tem como elemento indispensável a manifestação de vontade. Nesse sentido, escreveu Pontes de Miranda, interpretado por Alessandro Hirata em seu trabalho, acerca da natureza jurídica das chamadas relações contratuais fáticas: "Trata-se de verdadeira manifestação de vontade, do mesmo modo que o direito reconhece as manifestações expressas e tácitas. Assim, teríamos uma manifestação de modo tácito, como tantas outras. (...) A peculiariedade está no fato de ter sido o conteúdo da manifestação de vontade preestabelecido, tendo a mesma eficácia de negócio jurídico típico" (Cf. PONTES DE MIRANDA, Francisco Cavalcanti. Tratado de direito privado - Parte especial - Tomo XXXVIII - Direito das obrigações: Negócios jurídicos bilaterais e negócios jurídicos
} 
a admissão dos contratos-fáticos, assim entendidos aqueles iniciados sem a manifestação de vontade formal das partes, na prática, permitiu à doutrina e à jurisprudência pátrias buscar soluções mais adequadas nos casos de nulidade de contrato de trabalho, tal como se depreende do seguinte trecho do acórdão do Supremo Tribunal Federal, com relatoria do Ministro Gilmar Mendes, em que se discutiu a possibilidade de averbação do período trabalhado por menor de 14 anos, para fins previdenciários:

[...] Também entre nós não parece existir razão para que se atribua efeito retroativo à decretação de nulidade do contrato de trabalho. Na ausência de disposição expressa, como a do direito italiano, e à falta de um desenvolvimento doutrinário, no tocante às 'Relações Contratuais Fáticas', há de admitir a legitimidade das pretensões decorrentes da relação de emprego, ainda que esta venha a ser declarada inválida. Do contrário, ter-se-ia a norma protetiva aplicada contra os interesses daquele a quem visa proteger. Esta constitui sem dúvida a única solução compatível com a natureza tutelar do direito do trabalho.

[...] Acentue-se, outrossim, que não há que se cogitar aqui da responsabilização da Previdência Social por ato ilícito de outrem, mas tão-somente de reconhecer o direito do trabalhador aos benefícios previdenciários, que não decorrem propriamente da higidez da relação de emprego, mas, e sobretudo, da prática do ato-fato-trabalho. ${ }^{81}$

Ainda sobre essa questão, destaque-se o seguinte trecho da obra de Orlando Gomes e Elson Gottschalk, transcrito no acórdão acima mencionado, que expõe o raciocínio segundo o qual a teoria anticontratualista orienta a resolução de questão relacionada à nulidade de contrato de trabalho, em conformidade com o espírito protetivo da legislação trabalhista:

A questão da ineficácia do contrato de trabalho seria resolvida em termos tão simples se fora possível aplicar ao mesmo, com todo rigor, a teoria

plurilaterais. Pressupostos. Vícios de direito. Vícios de objeto. Evicção. Redibição. Espécies de negócios jurídicos bilaterais e de negócios jurídicos plurilaterais. $3^{\text {º }}$ ed., Rio de Janeiro, 1972. p. 29 e ss. Apud HIRATA, Alessandro. Op. cit., p. 97-99).

${ }^{81}$ Agravo de Instrumento no $529.694-1 /$ RS. 
civilista das nulidades. Mas a natureza especial da relação de emprego não se compadece com a retroatividade dos efeitos da decretação da nulidade. O princípio segundo o qual o qual é nulo nenhum efeito produz não pode ser aplicado ao contrato de trabalho. É impossível aceitá-lo em face da natureza da prestação devida pelo empregado. Consistindo em força-trabalho, que implica em dispêndio de energia física e intelectual, é, por isso mesmo, insuscetível de restituição. Se a nulidade absoluta tem efeito retroativo, se repõe os contraentes no estado em que se encontravam ao estipular o contrato nulo, como se não fora celebrado, nenhuma parte tem o direito de exigir da outra o cumprimento da obrigação. Donde se segue que o empregado não tem o direito de cobrar o salário ajustado. Esta seria a consequiência inelutável do princípio da retroatividade da nulidade da nulidade de pleno direito.

Mas, é consequiência evidentemente absurda, ainda mesmo se admitindo que o trabalhador possa exigir a remuneração com fundamento na regra que proíbe o enriquecimento ilícito. Porque a verdade é que a retroatividade só teria cabimento se o empregador pudesse devolver ao empregado a energia que este gastou no trabalho. Mas, como isso não é possível, os efeitos da retroatividade seriam unilaterais, isto é, beneficiariam exclusivamente ao empregador, como pondera De La Cueva, ao criticar a opinião de Hueck-Nipperdey. Deve-se admitir em toda extensão o princípio segundo o qual trabalho feito é salário ganho. Pouco importa que a prestação de serviço tenha por fundamento uma convenção nula. Em direito do trabalho, a regra geral há de ser a irretroatividade das nulidades. $\mathrm{O}$ contrato nulo produz efeitos até a data em que for decretada a nulidade. Subverte-se, desse modo, um dos princípios cardeais da teoria civilista das nulidades. A distinção entre os efeitos do ato nulo e do ato anulável, se permanece para alguns, não subsiste em relação a êste. ${ }^{82}$

Com efeito, porquanto almejassem os contratualistas atribuir o mesmo tratamento dos contratos em geral ao contrato de trabalho, a realidade social passou a exigir solução para problemas cujos conceitos e normas estáticos não eram capazes de resolver. Contudo, tais exigências não tiveram o condão de desvirtuar por completo a

${ }^{82}$ Curso de direito do trabalho. São Paulo: Forense, 1968. p. 123. 
natureza contratual da relação entre empregado e empregador, impondo-se, na verdade, o desapego aos moldes civilistas, além da quebra do conceito tradicional de negócio jurídico.

Por outro lado, não se pode sustentar a prevalência da teoria anticontratualista, pois, em virtude da forte interferência estatal, as normas de ordem pública inserem-se automaticamente no contrato como restrições à autonomia privada das partes. Tais restrições, da mesma forma, não configuram inexistência de contrato, uma vez que haverá liberdade de contratar, ou seja, haverá espaço para a manifestação de vontade, mesmo nos atos de adesão a condições previamente estipuladas.

Claro está que a essência do contrato não é a definição de seu conteúdo, e sim a própria vontade de contratar. Mesmo aquele que adere a cláusulas previamente estipuladas pelo outro contratante ou por terceiro celebra contrato. Como esclarece Nelson Mannrich, a liberdade contratual não pode ser confundida com o contrato em si mesmo: o que se está em crise é a autonomia da vontade na formação dele. ${ }^{83}$

Destaque-se, além disso, que a interferência estatal é típica de economias capitalistas que já sofreram as consequências do individualismo reforçado pelo poder econômico. Assim, a intenção do Estado é coibir abusos e impedir que o economicamente mais forte na relação contratual imponha sua vontade e crie uma situação de injustiça, já que a liberdade meramente formal entre sujeitos com desigual capacidade de negociação - como ocorre na relação de emprego - não leva ao estabelecimento de padrões adequados de comportamento. Em virtude disso, o legislador trabalhista limitou a autonomia da vontade dos sujeitos da relação de trabalho, estabelecendo condições mínimas de contratação, por meio de normas de natureza cogente, que se incorporam ao contrato de trabalho.

A esse respeito, observa Estêvão Mallet não haver nada de extraordinário, vez que, mesmo no campo dos contratos civis, nos quais, geralmente, é conferida autonomia mais ampla às partes, a liberdade de contratar sofre limitações - até porque, não se pode confundir autonomia contratual com soberania. Apesar de na esfera trabalhista tais limites serem mais rígidos, especialmente no campo das relações individuais de trabalho, não se chega a desnaturar a relação jurídica que se estabelece entre empregado e empregador. O vínculo contratual existente entre eles não se transforma em

${ }^{83}$ A modernização.... Op. cit., p. 104. 
um liame puramente objetivo, para cuja formação deixe de ter relevância a manifestação de vontade. $^{84}$

Além disso, a autonomia contratual não se manifesta somente na formação do contrato, estando presente em toda a vida contratual, mesmo após sua extinção. Deve-se distinguir o acordo de vontades, em si, essencial para a existência do contrato, da possibilidade de regulamentação das condições contratuais, as quais podem ser estabelecidas unilateralmente por uma das partes ou por terceiros, como ocorre nos contratos de adesão, típicos do direito consumerista. ${ }^{85}$ Como observa Nelson Mannrich, o essencial, em matéria de contrato, é a liberdade do sujeito para constituir a relação e não a oportunidade de participar da elaboração de determinada cláusula. ${ }^{86}$

\subsection{Características}

O contrato de trabalho é marcado por certas características, definidas pela doutrina a partir do entendimento majoritário quanto à natureza contratual, as quais imprimem marca relevante ou distinta à sua estrutura ou dinâmica operacional. Resumidamente, pode-se afirmar que se trata de um pacto de direito privado, sinalagmático e consensual, celebrado intuito personae em relação ao empregado, e de trato sucessivo e de atividade, dotado de onerosidade, alteridade e complexidade.

Embora nele prevaleçam normas de ordem pública, o contrato de trabalho corresponde a um pacto do direito privado, com caráter sinalagmático, por basearse na autonomia privada das partes, as quais se obrigam reciprocamente. ${ }^{87}$ Salvo algumas exceções, o ajuste entre as partes dispensa formalidades, sendo a consensualidade a regra geral.

É celebrado com caráter intuito personae em relação ao empregado, porque não permite substituição do encarregado do trabalho, salvo

${ }^{84}$ Contrato de trabalho, autonomia.... Op. cit., p. 17.

${ }^{85}$ Cesarino Junior qualifica o contrato de trabalho como sendo um contrato de adesão, especialmente nas grandes indústrias (Cf. Op. cit., p. 108).

${ }^{86}$ CESARINO JUNIOR, Antonio Ferreira. Op. cit., p. 105.

${ }^{87}$ Segundo a doutrina, o sinalagma característico dos contratos de trabalho é distinto do dos contratos civis. Isso porque as obrigações de cada um das partes são aferidas tomando-se o contrato como um todo, e não apenas o contraponto de obrigações específicas. Essa concepção explica a obrigatoriedade de pagamento de salário, mesmo ausente a prestação de serviços, como nas hipóteses de interrupção contratual (Cf. BARROS, Alice Monteiro. Op. cit., p. 238 e DELGADO, Mauricio Godinho. Curso de direito.... Op. cit., p. 20). 
esporadicamente ou com a anuência dele, ${ }^{88}$ sob pena de descaracterizar a figura contratual. Tal característica pode ser mais acentuada em relação a alguns empregados, tais como artistas e atletas profissionais, pois, nesses casos, a prestação de serviços envolve valores como habilidades intelectuais e físicas, determinantes para as atividades a serem desempenhadas. Apenas excepcionalmente a doutrina admite o caráter intuito personae em relação ao empregador.

O trato sucessivo refere-se ao fato de que as prestações centrais do contrato de trabalho, como disponibilização da força de trabalho e verbas salariais, sucedem-se continuamente no tempo, cumprindo-se e vencendo-se, seguidamente, ao longo do prazo contratual. Portanto, não se esgotam com a realização de um ato singular. Além disso, é pressuposta a realização de uma atividade dentro da estrutura empresarial, uma prestação de fazer, que se cumpre continuamente no tempo.

Trata-se, também, de um contrato oneroso, pois cada uma das partes contribui com uma ou mais obrigações economicamente mensuráveis, havendo, dessa forma, transferência recíproca, ainda que desigual, de riquezas. No âmbito de um contrato de trabalho, necessariamente, essa troca ocorre entre disponibilização da força de trabalho, por parte do empregado, e pagamento de salário, por parte do empregador. Nesse sentido, se a prestação de serviços realizar-se em intuito contraprestativo por parte do trabalhador, caso em que o trabalho será motivado por objetos benevolentes, altruísticos e afins, o contrato existente não será trabalhista devido à falta da onerosidade. ${ }^{89}$

A alteridade revela-se no fato de os riscos e resultados serem inerentes à prestação de serviços e ao próprio empreendimento empresarial, incidindo, exclusivamente, sobre o empregador. Desse modo, são alheios à figura do empregado e a atribuição dos possíveis danos independe de ajuste tácito ou expresso fixado pelas partes contratuais. Por outro lado, também pela alteridade, os rendimentos do negócio não são diretamente atribuídos ao empregado. ${ }^{90}$

\footnotetext{
${ }^{88}$ Tal como nos casos de afastamento do empregado por doença, parto, acidente, greves, entre outras ocorrências.

${ }^{89}$ Não descaracteriza a onerosidade do contrato de trabalho o fato de ser a remuneração paga parcialmente por terceiros, como no caso das gorjetas (Cf. DELGADO, Mauricio Godinho. Curso de direito.... Op. cit., p. 22).

${ }^{90}$ Como exemplo, Alice Monteiro de Barros cita a situação do jogador de futebol que obtém título de campeão, o qual poderá conceder-lhe um benefício econômico ou maior prestígio, mas a vitória no campeonato é atribuída ao clube, com registro nos seus anais e/ou na entidade organizadora do campeonato (Cf. BARROS, Alice Monteiro. Op. cit., p. 240).
} 
Finalmente, trata-se de um contrato complexo porque podem associar-se a ele outros contratos, que tendem ser acessórios. ${ }^{91}$ Consequentemente, na maioria dos casos, tais contratos tendem a sofrer os efeitos da dinâmica do próprio contrato de trabalho e serem extintos quando esse é rescindido.

Além dessas características, de acordo com a doutrina, há outros elementos intrínsecos ao contrato de trabalho que não diferem, em geral, daqueles já indicados pela teoria civilista clássica, os quais são divididos em três categorias: essenciais (também chamados jurídico-formais), naturais e acidentais.

Os elementos essenciais são imprescindíveis à formação de qualquer figura jurídica contratual.Sua ausência ou irregularidade pode comprometer a própria existência ou validade de qualquer contrato. Já os elementos naturais, embora não sejam vitais à existência do contrato, são comuns, recorrentes e quase inevitáveis no caso concreto. Por fim, os elementos acidentais são circunstanciais e episódicos, frutos da autonomia privada das partes e da implementação de certas condições previstas em lei.

A capacidade das partes, a licitude do objeto, a higidez da manifestação da vontade (consenso válido) e a forma prescrita ou não vedada em lei são considerados elementos essenciais, comuns a qualquer figura contratual - obviamente, com as adequações próprias a cada ramo do direito. Nesse sentido, para a celebração de qualquer contrato, os sujeitos contratantes devem gozar de plena capacidade civil, ou seja, ter aptidão para exercer, por si ou por outrem, atos da vida civil. Até a publicação da Lei $\mathrm{n}^{\circ}$ 10.406/2002, que institui a versão mais recente do Código Civil, as regras sobre capacidade trabalhista, isto é, a capacidade para o exercício de atos da vida laborativa, diferiam em alguns aspectos das regras gerais civilistas. Antes da publicação da última edição do Código Civil, a capacidade plena para os atos da vida civil somente era atingida aos 21 anos de idade, enquanto a maioridade trabalhista começava aos 18 anos, como se depreendia da redação original do artigo 402, da Consolidação das Leis do Trabalho. Com a publicação da nova edição do diploma civilista, essa diferença deixou de existir, sendo a maioridade, em qualquer hipótese, atingida aos 18 anos.

O empregado com idade entre 16 e 18 anos é considerado relativamente capaz ou incapaz, admitindo-se a prestação válida de serviços nesse período

\footnotetext{
${ }^{91}$ São exemplos de contratos acessórios os pactos concernentes a depósitos de instrumentos de trabalho, comodato de imóvel residencial, mandato etc. (Cf. DELGADO, Mauricio Godinho. Curso de Direito.... Op. cit., p. 23).
} 
somente para alguns atos e com autorização de seu representante legal. A legislação, em verdade, determina os atos de trabalho que não podem ser praticados pelo menor, Assim, o menor pode prestar serviços, bem como assinar, sozinho, recibo de pagamentos contratuais ao longo do desenvolvimento do pacto (art. 439, CLT); contudo, dependerá da assistência de seu representante legal para celebrar contrato de trabalho, requerer a expedição de Carteira de Trabalho e Previdência Social, bem como assinar termo de rescisão de contrato de trabalho (art. 17, $\S 1^{\circ}$, e art. 439, ambos da CLT). O trabalho do menor de 16 anos é permitido somente na condição de aprendiz, dos 14 aos 24 anos de idade.

Por fim, a legislação veda a prestação de serviços pelo menor de 18 anos de idade nas seguintes condições: em locais prejudiciais à sua formação, ao seu desenvolvimento físico, psíquico, moral e social e em horários e locais que não permitam a frequência à escola (art. 403, parágrafo único, CLT); em período noturno, considerado este o que for executado no período compreendido entre às 22 (vinte e duas) e às 5 (cinco) horas; em locais ou serviços perigosos ou insalubres ou prejudiciais à sua moralidade (art. 405, I e II, CLT). Ademais, o trabalho exercido nas ruas, praças e outros logradouros dependerá de prévia autorização do Juiz de Menores, ao qual cabe verificar se a ocupação é indispensável à sua própria subsistência ou à de seus pais, avós ou irmãos, e se dessa ocupação não poderá advir prejuízo à sua formação moral (art. 405, §2º CLT).

Quanto à licitude do objeto, a ordem jurídica trabalhista exige, para que seja reconhecida a validade do contrato, que ele tenha por objeto a prestação de trabalho lícito. Deve-se distinguir, nesse sentido, o trabalho ilícito do trabalho irregular: o primeiro compõe um tipo penal ou concorre diretamente para ele; o segundo realiza-se em desrespeito a norma imperativa vedatória do labor em certas circunstâncias ou envolve certos tipos de empregados - a título de exemplo, cite-se a prestação de serviços no período noturno ou em ambiente perigoso ou insalubre por empregados menores, bem como o trabalho executado por estrangeiro sem autorização administrativa para prestação de serviços. ${ }^{92}$ Tal distinção é importante no pelo fato de ordem jurídica laboral tender a conferir plenos efeitos à prestação de trabalho irregular,mas não ilícita, no âmbito de uma relação de emprego. O reconhecimento de efeitos jurídicos não elimina a necessidade de sanar-se a irregularidade ou extinguir-se o contrato. ${ }^{93}$

92 Embora um trabalho irregular possa, também, assumir o caráter de conduta ilícita, isso não necessariamente de verifica (Cf. DELGADO, Mauricio Godinho. Contrato de trabalho.... Op. cit., p. 28). ${ }_{93}$ A doutrina aponta duas situações concretas em que, não obstante o reconhecimento da ilicitude na prestação de trabalho, a ordem jurídica trabalhista atribui plenos efeitos jurídicos em favor dos empregados: 
Além da capacidade das partes e do objeto lícito, exige-se a ocorrência de manifestação de vontade livre de vícios pelos sujeitos contratuais. Contudo, por todas as razões já expostas quando do estudo da natureza jurídica do pacto laboral, a aferição dessa manifestação no cotidiano trabalhista é menos relevante do que no cotidiano regulado pelo direito civil. ${ }^{94}$

Por fim, também no direito do trabalho observa-se a premissa segundo a qual não se exige forma específica para os atos jurídicos contratados na vida privada, partindo-se do pressuposto de que as partes podem eleger mecanismos eficientes e práticos para enunciação de sua vontade conjugada. Assim, o contrato de trabalho é pacto não solene, podendo ser licitamente ajustado até mesmo de forma tácita, consoante definição do texto consolidado. Mesmo nessa hipótese, as cláusulas fixadas por normas de ordem pública, de caráter cogente, serão aplicáveis. Como resultado, a existência do contrato pode ser comprovada por qualquer meio probatório juridicamente válido, inclusive indícios e presunções. ${ }^{95}$

No tocante aos elementos naturais, embora não sejam fundamentais para a formação do contrato de trabalho, tendem a comparecer recorrentemente em sua estrutura e dinâmica concretas. Como exemplo, cite-se a cláusula que dispõe sobre a jornada de trabalho a ser cumprida pelo empregado no curso do pacto laboral, a qual, dificilmente, não integrará o acordo celebrado entre empregado e empregador, ainda que tacitamente. $^{96}$

Finalmente, são considerados elementos acidentais aqueles que, embora circunstanciais e episódicos, quando inseridos, alteram significativamente a

i) nos casos de comprovado desconhecimento da ilicitude pelo trabalhador, tais como empregados de lojas onde são vendidos produtos contrabandeados e/ou falsificados; e ii) nos casos de nítida dissociação do trabalho prestado e do núcleo da atividade ilícita, a exemplo dos empregados que atuam na segurança de locais onde se exploram jogos de azar.

${ }^{94}$ A pesquisa sobre a higidez da manifestação de vontade pode ganhar relevo em situações específicas, tal como ocorre em relação aos contratos celebrados a termo por prazo longo, em que a ruptura por uma das partes torna-se demasiado onerosa para a outra. Nessa hipótese, se comprovado efetivo vício na manifestação de vontade (erro, dolo, coação), pode o contrato ser anulado, suplantando o ônus da ruptura contratual desmotivada por ato da parte lesada (Cf. DELGADO, Mauricio Godinho. Contrato de trabalho.... Op. cit., p. 30).

95 A legislação trabalhista exige forma expressa somente em casos excepcionais, como no dos contratos celebrados por prazo determinado, contratos de artistas e atletas de futebol profissionais etc., bem como em algumas condições específicas dos contratos de trabalho em geral, como ocorre na pactuação de regime de compensação de jornada de trabalho (Súmula 85, II, TST).

${ }^{96}$ Mauricio Godinho Delgado cita três exemplos, como exceções à habitual incidência da cláusula de jornada de trabalho: trabalhadores domésticos, em relação aos quais a legislação ainda não fixou parâmetros concretos sobre a jornada de trabalho a ser cumprida por tais empregados; empregados ocupantes de cargo ou função de confiança e empregados que exercem atividade externa, os quais estão excluídos de controle de jornada pelo empregador (Cf. Contrato de trabalho.... Op. cit., p. 33). 
estrutura e os efeitos do contrato de trabalho, tais como termo e condição. Embora mais frequente do que a estipulação de condições, ${ }^{97}$ a estipulação de termo nos contratos de trabalho é exceção, viável apenas se configuradas hipóteses legais tipificadas e expressas, sendo regra geral a celebração de contratos por prazo indeterminado.

Além desses elementos, comuns a quaisquer figuras jurídicas contratuais, a doutrina aponta outros; porém, específicos do contrato de trabalho, chamados elementos fático-jurídicos. Tais elementos estão relacionados ao modo de prestação de serviços característico da relação de emprego e, por tal razão, são imprescindíveis para diferenciá-la das demais relações contratuais que envolvam a prestação de trabalho por uma ou várias pessoas em favor de outrem. Por sua importância, serão abordados em tópico específico.

\subsubsection{Elementos fático-jurídicos da relação de emprego}

A prestação de trabalho por uma pessoa física a outrem pode concretizar-se segundo fórmulas relativamente diversas entre si que, tecnicamente, não possuem natureza de relação de emprego. Como esclarece Mauricio Godinho Delgado, a prestação de trabalho pode emergir como uma obrigação de fazer pessoal, mas sem subordinação (trabalho autônomo em geral); como uma obrigação de fazer, sem pessoalidade e subordinação (também trabalho autônomo); como uma obrigação de fazer pessoal e subordinada, mas episódica e esporádica (trabalho eventual). Em todos esses casos, não se configura uma relação de emprego, tratando-se de relações jurídicas que, em princípio, não se encontram sob a égide da legislação trabalhista e, até o advento da Emenda Constitucional $n^{\circ} 45 / 2004$, nem se encontravam sob jurisdição da Justiça do Trabalho. ${ }^{98}$ A caracterização da relação de emprego é, pois, fundamental para o direito do trabalho, assegurando a incidência de todos os seus princípios, regras e institutos específicos. Ela resulta da conjugação de certos elementos, reunidos em um dado contexto social ou interpessoal.

98 Curso de direito.... Op. cit., p. 287. 
De forma combinada, o caput do artigo $2^{\circ}$ e o caput do artigo $3^{\circ}$, ambos da Consolidação das Leis do Trabalho, ${ }^{99}$ mencionam os cinco elementos que caracterizam a relação de emprego e, consequentemente, o contrato de trabalho clássico: a prestação de trabalho por pessoa física, com pessoalidade, habitualidade, onerosidade e subordinação. Esses elementos ocorrem no mundo dos fatos, existindo independentemente do direito e por causa de sua relevância sociojurídica são reconhecidos pelo direito, que lhes confere efeitos compatíveis, daí serem chamados elementos "fático-jurídicos". São também chamados "elementos conceitualmente essenciais", pois se alojam na raiz do fenômeno a ser demonstrado.

Nesse contexto, o trabalho prestado por pessoa física revela os bens jurídicos - e mesmo éticos- tutelados pelo direito do trabalho: vida, saúde, integridade física e moral, bem-estar, lazer etc. Tratam-se de bens ligados à pessoa humana, não podendo ser usufruídos por pessoas jurídicas. Disso decorre que a pessoa do trabalhador há de ser, sempre, uma pessoa natural. ${ }^{100}$ Apenas o empregador pode ser, indistintamente, pessoa física ou jurídica.

O elemento da pessoalidade, por sua vez, está diretamente relacionado ao anterior, mas dele guarda uma importante distinção. O trabalho pode ser prestado por pessoa física e só é prestado com pessoalidade quando, necessariamente, é executado pela mesma pessoa, não se admitindo variação em relação à figura do empregado. Afirma-se, nesse sentido, que a relação de emprego é celebrada intuito persone com relação ao empregado, pois esse não poderá fazer-se substituir intermitentemente por outro trabalhador ao longo da concretização dos serviços pactuados. ${ }^{101}$

Como elemento fático-jurídico essencial para a caracterização de uma relação de emprego entre as partes, a pessoalidade produz efeitos não somente no

\footnotetext{
${ }^{99}$ Art. $2^{\circ}$, caput, CLT - Considera-se empregador a empresa, individual ou coletiva, que, assumindo os riscos da atividade econômica, admite, assalaria e dirige a prestação pessoal de serviço (...). Art. $3^{\circ}$, caput, CLT Considera-se empregado toda pessoa física que prestar serviços de natureza não eventual a empregador, sob a dependência deste e mediante salário.

${ }^{100}$ De acordo com Mauricio Godinho Delgado, a palavra "trabalho" já denota, por si, atividade realizada por pessoa natural, ao passo que o verbete "serviços" abrange obrigação de fazer realizada quer por pessoa física, quer pela jurídica (Cf. Curso de direito.... Op. cit., p. 291).

${ }^{101}$ Há situações ensejadoras de substituição do empregado sem que seja suprimida a pessoalidade inerente à relação empregatícia. Em primeiro lugar, cite-se as situações de substituição eventual autorizadas pelo próprio empregador; obviamente, substituições consentidas intermitentes e constantes podem caracterizar um contrato de prestação de serviços autônomos e sem pessoalidade - como ocorre em relação aos representantes comerciais e seus prepostos, o que colocaria a relação jurídica examinada distante da figura legal típica da relação de emprego. Em segundo lugar, cite-se as substituições normativas autorizadas (por lei ou norma autônoma), tais como férias, licença-gestante, afastamento para cumprimento de mandato sindical etc. (Cf. DELGADO, Mauricio Godinho. Curso de direito.... Op. cit., p. 291)
} 
instante da configuração do vínculo de emprego, mas também no momento de sua extinção, o que quer dizer que a morte do empregado, por exemplo, extingue o contrato entre as partes. Pelas mesmas razões, caso a prestação de serviços torne-se inviável, em algum momento do contrato, e por certo período, devem incidir as normas de suspensão ou interrupção do contrato de trabalho, dependendo do caso concreto.

Por fim, ressalte-se que o elemento da pessoalidade não se refere à figura do empregador, prevalecendo, no direito do trabalho, a diretriz da despersonalização da figura do empregador. É o que se prevê nos artigos 10 e 448, da Consolidação das Leis do Trabalho, que, tratando da sucessão trabalhista, preservam os direitos adquiridos dos empregados ou contratos de trabalho nos casos de alteração de propriedade ou na estrutura jurídica da empresa, o empregador.

A não-eventualidade revela o ideal de permanência que rege o direito do trabalho em duas dimensões: a continuidade das relações de emprego, por meio da qual se incentiva a permanência indefinida do vínculo, em detrimento da celebração de contratos precários; e, de outro lado, a continuidade inerente ao modo de prestação de serviços, que, ao lado dos demais elementos fáticos-jurídicos, responde pela formação e desenvolvimento da relação de emprego.

Assim, para configurar relação de emprego, é necessário que o trabalho seja prestado em caráter de permanência,ainda que por curto período de tempo, ou continuidade, como preferiu a Lei $\mathrm{n}^{\circ}$ 5.859/72 (Lei do Trabalho Doméstico), ao utilizar a expressão "serviços de natureza contínua". Todavia, o conceito de não-eventualidade é dos mais controvertidos do direito do trabalho, tendo a doutrina construído várias teorias, com o fim de estabelecer com maior clareza seu sentido, quais sejam, teoria da descontinuidade, teoria do evento, teoria dos fins do empreendimento e teoria da fixação jurídica. Embora produzam efeitos distintos, dependendo do caso concreto, elas têm em comum o fato de definirem a não-eventualidade ou a descontinuidade pelo seu aspecto negativo, mais especificamente, definindo o que é trabalho eventual.

Em referência à Lei do Trabalho Doméstico, a teoria da descontinuidade define o eventual como sendo o trabalho descontínuo e ininterrupto, com relação a determinado tomador de serviços. ${ }^{102}$ Já pela teoria do evento, a eventualidade do

${ }^{102}$ De acordo com Mauricio Godinho Delgado, a teoria da descontinuidade tem implícita idéia de intermitência, ou continuidade, rejeitada pela Consolidação das Leis do Trabalho. Nesse sentido, se presentes os demais elementos fáticos-jurídicos da relação de trabalho, não seria eventual o trabalhador que presta 
trabalho é determinada pelo fato de ser a contratação por curto período de tempo, motivada por acontecimento ou evento específico, podendo a dilação temporal mais ampliada afastar esse caráter.

A teoria dos fins do empreendimento ou fins da empresa, por sua vez, consiste na formulação teórica mais prestigiada. De acordo com ela, será considerado trabalhador eventual aquele que for chamado para realizar tarefa não inserida nos fins usuais da empresa e que, por essa razão, são consideradas esporádicas e de curta duração. Portanto, a aferição da natureza eventual dos serviços prestados é feita em vista das atividades regulares da empresa.

Finalmente, a teoria da fixação jurídica ao tomador de serviços informa ser eventual o trabalhador que não se fixa a uma fonte de trabalho, ao contrário do que ocorre com o empregado, que se fixa.

Com base em tais formulações teóricas, Mauricio Godinho Delgado definiu o trabalho eventual da seguinte forma: a) há descontinuidade na prestação de serviços, não havendo permanência na organização com ânimo definitivo; b) não há fixação jurídica a uma única fonte de trabalho, havendo pluralidade de tomadores de serviços; c) o trabalho prestado é de curta duração; d) a natureza do trabalho tende a ser concernente a evento certo, determinado e episódico no tocante à regular dinâmica do empreendimento tomador de serviços; e, em consequência, e) a natureza do trabalho prestado tenderá a não corresponder, também, ao padrão dos fins normais do empreendimento. ${ }^{103}$

Já a onerosidade, como elemento fático-jurídico componente da relação de emprego, denota o caráter essencialmente econômico dessa relação. Ao valor econômico da força de trabalho colocada à disposição do empregador deve corresponder uma contrapartida econômica em benefício do trabalhador, consubstanciada no complexo de verbas contraprestativas pagas pelo empregador ao empregado em virtude da relação de emprego pactuada.

serviços ao tomador por diversos meses seguidos, mas apenas em domingos ou finais de semana (caso de garçons de clubes campestres, por exemplo), de forma descontínua, embora permanente. Por sua vez, a Lei do Trabalho Doméstico adotou a teoria da descontinuidade com o claro objetivo de não enquadrar na figura técnico-jurídica de empregado doméstico o trabalhador eventual, conhecido como "diarista" (Cf. Curso de direito.... Op. cit., p. 295).

${ }^{103}$ Ibidem, p. 297. 
A análise do elemento onerosidade em uma relação de emprego deve ser feita tanto no plano objetivo, quanto no plano subjetivo. No plano objetivo, a onerosidade manifesta-se pelo pagamento, pelo empregador, do salário e de todas as verbas que compõem a remuneração do empregado à prestação de serviços. Essas verbas podem ser pagas de formas distintas e variadas - em dinheiro ou parcialmente em utilidades; por dia, semana, quinzena ou mês; segundo modalidade fixa ou fórmula variável de cômputo razão pela qual o operador do direito normalmente não encontra qualquer dificuldade para vislumbrar a presença do elemento onerosidade na relação de trabalho investigada.

Diante da constatação no plano objetivo, geralmente, torna-se desnecessária a pesquisa da dimensão subjetiva da onerosidade, posto já ser obvia. Entretanto, em algumas raras situações, a investigação sobre a dimensão subjetiva será a única via hábil a permitir aferir-se a existência ou não do elemento onerosidade na relação de trabalho vivenciada pelas partes. Como exemplo dessas raras situações, Mauricio Godinho Delgado cita as hipóteses de servidão disfarçada e de trabalho voluntário, comunitário, filantrópico ou religioso, em que, embora haja efetiva prestação de serviços, não se verifica pagamento de prestação onerosa por parte do tomador de serviços. Nessas situações, apenas o exame da dimensão subjetiva da onerosidade demonstrará ocorrência ou não de trabalho na relação social construída entre as partes. ${ }^{104}$ Em suma, em tais casos, não há intenção econômica envolvida na prestação de serviços, seja por parte do tomador de serviços, no caso da servidão disfarçada, seja por parte do prestador, nas demais hipóteses.

Por fim, conforme já mencionado, a subordinação constitui o principal elemento fático-jurídico da relação de emprego, o traço distintivo fundamental entre a relação de emprego e as demais formas de prestação de trabalho pessoal. Note-se a justificativa contida no relatório enviado à Assembleia Nacional Portuguesa sobre a Proposta de Lei que regulamentou o contrato de trabalho naquele país:

\footnotetext{
${ }^{104}$ Há situações fronteiriças, contudo, em que a própria ordem jurídica nega a intenção onerosa ao trabalho efetivamente prestado, afastando, em consequência, a caracterização de vínculo de emprego. De acordo com a jurisprudência consolidada, é o que se passa com a situação da esposa ou companheira com relação ao marido ou companheiro, em virtude do trabalho doméstico; nesse caso, não se reconhece a onerosidade do vínculo de emprego, mas somente a onerosidade própria à comunhão societária. Apenas para fins previdenciários é que tal período poderá ser comprovado como exercício de trabalho autônomo pela mulher, no âmbito da residência (Cf. DELGADO, Mauricio Godinho. Curso de direito.... Op. cit., p. 299-300).

${ }^{104}$ MATOS, Albertino de. Op. cit., p. 46.
} 
Com efeito, o critério da subordinação jurídica do empregado ou assalariado ao respectivo patrão revelava-se com tal rigidez em toda a legislação, como característica do laço contratual, que muitas formas de prestação de trabalho escapavam à proteção legal sem que o justificasse a diversidade substancial, apenas aparente, da natureza do contrato.

De-certo que o estado de subordinação ou dependência pessoal deve assinalar a linha divisória entre o contrato de trabalho e os demais contratos em que a actividade pessoal de uma das partes constitue o objecto da convenção; mas tem de admitir-se que, além da subordinação juridica, em muitos casos, se considere o estado dependência económica como suficiente para afirmar o vínculo contratual. ${ }^{105}$

A subordinação consiste na situação jurídica derivada do contrato de trabalho, pela qual o empregado compromete-se a acolher o poder de direção empresarial no modo de realização de sua prestação de serviços, e revela uma limitação contratual da autonomia privada do empregado, para o fim de transmitir ao empregador o comando sobre a atividade que desempenhará. É responsável por distinguir o contrato de trabalho de outras figuras afins e, evidentemente, o trabalho subordinado do trabalho autônomo.

A subordinação deve ser encarada exclusivamente do prisma objetivo, ou seja, da forma da prestação de serviços, e não do empregado, ainda que essa inaceitável situação de sujeição possa ocorrer com frequência.

A visão subjetiva da subordinação se expressa na com maior proximidade na palavra "dependência", a propósito, utilizada no caput do artigo $3^{\circ}$, da Consolidação das Leis do Trabalho, em referência à subordinação. Tal expressão acentua o vínculo pessoal entre as partes componentes da relação de emprego, sendo resultado de uma fase teórica em que ainda não se havia firmado a noção essencialmente jurídica do fenômeno subordinação. Por outro lado, por meio de tal expressão, não é possível captar a presença de subordinação na hipótese de trabalhadores intelectuais ou ocupantes de altos cargos na estrutura hierárquica da empresa, posto não estarem sob sujeição ou dependência de qualquer pessoa.

${ }^{105}$ MATOS, Albertino de. Op. cit., p. 46. 
De qualquer forma, a dualidade poder de direção versus subordinação, hoje consolidada, não autoriza o recurso à visão subjetiva de tal elemento; portanto, onde se lê "dependência" no texto consolidado, deve-se entender "subordinação", cuja expressão tem viés puramente jurídico. ${ }^{106}$ Sobre a definição do termo "subordinação jurídica", Nelson Mannrich reproduz lição de Paul Colin:

[...] um estado de dependência real, produzido por um direito, o direito do empregador de comandar, de dar ordens, e donde decorre a obrigação correspondente para o empregado de se submeter a estas ordens. Esta é a razão por que se tem chamado a isto de subordinação jurídica, para contrastar principalmente com a subordinação econômica e a subordinação técnica que importa, sem dúvida, uma direção a dar ao trabalho do empregado. Na subordinação jurídica, ao contrário, trata-se de um direito geral de fiscalizar a atividade de outrem, de interrompê-la, de suscitá-la à vontade, de traçar limites, sem que seja necessário controlar continuamente o valor técnico dos trabalhos efetuados. Direção e fiscalização - tais são os dois polos da subordinação jurídica. ${ }^{107}$ Mauricio Godinho Delgado esclarece que antigas posições doutrinárias da teoria justrabalhista não
enxergavam o caráter eminentemente jurídico do fenônemo da subordinação, acentuando a idéia de
dependência (que tem matiz pessoal e não objetiva), ora como dependência econômica, ora como
dependência técnica. A concepção de dependência econômica seria reflexo da assimetria econômico-social
entre empregado e empregador, como padrão genérico típico da moderna sociedade industrial; entretanto,
como elemento externo, tal assimetria não tem o condão de alterar o feixe jurídico de prerrogativas e deveres
inerentes à relação de emprego. Já a concepção de dependência técnica seria resultado da idéia de que o
empregador monopoliza, naturalmente, o conhecimento necessário ao processo de produção em que se
encontra inserido o empregado; contudo, a fragilidade de tal concepção é ainda mais latente, especialmente
em face do processo organizativo da empresa moderna, em que a tecnologia é adquirida e controlada pelo
empresário por meio de instrumentos jurídicos, ou seja, ele capta a tecnologia através de empregados
especializados que arregimenta, sem necessidade de absorver, ele próprio, tais conhecimentos (Cf. Curso....
Op. cit., p. 304-305).

${ }^{107}$ De la détermination du mandat salarié - Mandat, salarié et activité professionnelle. Paris: PUF, 1931. p. 97 Apud MANNRICH, Nelson. Modernização.... Op. cit., p. 121. 


\section{AUTONOMIA DA VONTADE E AUTONOMIA PRIVADA}

Em um momento em que temas como globalização, avanço do desemprego e flexibilização dominam a pauta dos operadores do direito do trabalho, a abordagem dos limites da autonomia privada das partes restringe-se ao seu aspecto coletivo, ou seja, a possibilidade de livre pactuação é discutida tão somente no cenário dos atores sociais que exercem a autonomia coletiva dos particulares. Além disso, baseados na ampla regulamentação pelo Estado das relações individuais de trabalho, alguns autores defendem que, nessa seara, pouco ou nenhum espaço é reservado para o exercício da autonomia privada dos particulares, enquanto outros, buscando amenizar esse entendimento, assumem que, no tocante às relações individuais de trabalho, em tudo o que não é objeto de imposição legal "domina Il principio dell'autonomia individuale", como enuncia Estêvão Mallet, ao reproduzir expressão do autor italiano Barassi. ${ }^{108}$

Apesar do reduzido número de estudos a respeito do tema, bem como a falta de consenso entre os autores, fato é que a evolução da sociedade no campo econômico, científico e tecnológico, não apenas no Brasil, mas em todo o mundo, impôs novos direitos e deveres aos sujeitos do contrato de trabalho, incluindo a necessidade de resguardar novos interesses; contudo, a legislação não acompanhou tal evolução. Nesse contexto, a aparente suficiência do sistema legal trabalhista passou a conviver com omissões do legislador quanto às questões originadas de tais avanços, dando margem a questionamentos acerca de eventuais limites à autonomia privada das partes no âmbito das relações individuais de trabalho.

Antes de adentrar no estudo de tais limites, é necessário conhecer os contornos dessa autonomia, que permite aos indivíduos criar regras para si mesmo e para a satisfação de suas próprias necessidades e pretensões concretas. Ainda, é preciso desvendar questões como: o que significa a autonomia em si considerada? Qual é o papel da vontade nesse cenário? Os conceitos de autonomia privada e autonomia da vontade correspondem ao mesmo instituto jurídico? São estas, pois, algumas das questões que serão tratadas no capítulo.

${ }^{108}$ Prática de direito..... Op. cit., p. 18 
Sendo o direito civil o campo de aplicação, por excelência, da autonomia privada, em grande parte, a abordagem de tais questões será orientada por teorias e princípios próprios da doutrina civilista.

\subsection{Autonomia}

Etimologicamente, a palavra autonomia resulta da conjunção de dois vocábulos gregos, autós e nomói. O primeiro deles transmite a ideia de si mesmo, representando uma qualidade ou condição inerente e peculiar a um ser. Já o segundo tem significado de norma ou regra. ${ }^{109}$

No campo das relações humanas, o termo assume o significado de independência, liberdade ou independência moral ou intelectual, faculdade de se governar por si mesmo, consoante lições de Érico de Pina Cabral:

É a faculdade de traçar suas próprias normas de conduta, sem que seja submetido a imposições de ordem estranha. Direito de tomar decisões livremente, com liberdade, independência moral e intelectual. É o contrário de heteronomia, que significa sujeição a uma lei exterior ou à vontade de outrem com ausência de autonomia. O heterônomo recebe do exterior as leis reguladoras de sua conduta, enquanto o autônomo rege-se através de um regramento próprio e interno. ${ }^{110}$

Emílio Betti identifica duas funções distintas dentro do ordenamento jurídico: a) como fonte de normas jurídicas, subordinada e dependente, que integram o próprio ordenamento jurídico; e b) como pressuposto e causa geradora de relações jurídicas já disciplinadas, em abstrato e em geral, pelas normas desse ordenamento.

\footnotetext{
109 HOUAISS, Antônio; VILLAR, Mauro de Salles. Dicionário Houaiss da língua portuguesa. Rio de Janeiro: Objetiva, 2001 Apud RODRIGUES JUNIOR, Otavio Luiz. Autonomia da vontade, autonomia privada e autodeterminação - Notas sobre a evolução de um conceito na Modernidade e na Pósmodernidade. Revista de informação legislativa, v. 41, n. 163, p. 113-130, jul./set. de 2004, p. 113.

${ }^{110}$ A "autonomia" no direito privado. Revista de Direito Privado, São Paulo, n. 19, p. 83-129, jul.set.2004.
} 
Na primeira função, a autonomia revela-se como competência para criar normas jurídicas, conferindo a quem dela está investido poder jurisdicional. Não se trata, nesse caso, do poder de regulamentação dos próprios interesses em esferas individuais, e sim da criação de normas abstratas, de aplicabilidade geral. É na segunda função que a autonomia permite a autorregulação dos interesses particulares, pois se realiza no terreno social, sendo apenas reconhecida e sancionada pelo ordenamento jurídico.

A partir do estudo da evolução histórica do contrato de trabalho, depreende-se que a possibilidade de autorregulamentação dos interesses por meio dos contratos em geral aumentou consideravelmente no período pós-Revolução Industrial, como reflexo da política de estímulo e garantia da propriedade privada. A autonomia, nesse contexto, foi tratada como uma espécie de "propriedade" do ser.

Com o reconhecimento da propriedade individual, a circulação de bens e a prestação de serviços entre os indivíduos foram entregues à autonomia privada, por meio da troca, dos empréstimos, da transmissão por morte e, assim, sucessivamente, mediante negócios jurídicos celebrados segundo interesses individuais e que garantiam, além da renovação dos bens, a própria coesão do sistema. ${ }^{111}$

Como capacidade dos indivíduos de determinar seu próprio comportamento individual, a autonomia constitui um dos pilares primordiais da liberdade. Esta, por sua vez, aparece tanto no sentido negativo, quando no positivo. No sentido negativo, é representada pela ausência de constrangimentos, possibilitando ao cidadão agir ou não, sem que fosse a isso obrigado ou impedido, tal qual ocorre nas chamadas liberdades existenciais, como direito à intimidade, liberdade de comunicação, de expressão, de religião, de associação, de profissão, entre outras. No sentido positivo, revela a capacidade de autodeterminação, ou seja, a possibilidade do sujeito de direitos de tomar decisões sem ser constrangido pela vontade de outras pessoas; presume que o indivíduo reúna as condições necessárias para agir, já que o indivíduo sem meios materiais mínimos de subsistência não pode ser considerado livre. ${ }^{112}$

\footnotetext{
${ }^{111}$ BETTI, Emílio. Teoria geral do negócio jurídico. Trad. Servanda Editora. Campinas: Servanda Editora, 2008. p. 77.

${ }^{112}$ FARIA, Roberta Elzy Simiqueli de. Autonomia da vontade e autonomia privada - uma distinção necessária. In FIUZA, César; SÁ, Maria de Fátima Freire de; NAVES, Bruno Torquato de Oliveira (Coord.). Direito Civil: Atualidades II. Bruno. Belo Horizonte: Del Rey, 2007. p. 59.
} 
Em ambos os sentidos, é necessária a proteção pelo Estado. Entretanto, especialmente no negativo, referida proteção não implica ausência de limites, pois, estando as pessoas inseridas em uma ordem maior (comunidade e sociedade), as esferas de liberdade individual são limitadas em favor da proteção de interesses coletivos, observada a proporcionalidade.

\subsection{Vontade}

Originário do termo latino voluntate, o termo "vontade", em estado de dicionário, significa a faculdade do indivíduo de "representar mentalmente um ato que pode ou não ser praticado em obediência a um impulso ou a motivos ditados pela razão; sentimento que incita alguém a atingir o fim proposto por esta faculdade; aspiração; anseio; desejo". ${ }^{113}$ O significado do termo "vontade" é estudado em vários campos do conhecimento, os quais tendem a sinalizar para a capacidade do indivíduo de querer algo, de ter um propósito de realização ou de agir em determinado sentido.

Segundo o pensamento filosófico, a vontade distingue o homem das outras espécies da natureza, marcando sua capacidade de agir livremente, "sem ser conduzido pela inelutabilidade do instinto". ${ }^{114}$ Nesse campo, cite-se Santo Agostinho, por exemplo, que enxerga na vontade o elemento que direciona o homem à vida, segundo suas aptidões mentais. ${ }^{115}$ Para Kant, a vontade consiste na faculdade do indivíduo de fazer ou deixar de fazer algo como lhe aprouver, segundo os ditames da razão. A vontade, nesse âmbito, é fundamento da ação (escolha). ${ }^{116}$ Já Hannah Arendt entende-a como o fundamento do discurso e da ação, os quais marcam a existência humana - o homem insere-se no mundo por meio de palavras e atos, por meio deles mostra quem realmente é e revela ativamente sua identidade pessoal e singular. ${ }^{117}$

113 FERREIRA, Aurélio Buarque de Holanda. Novo Aurélio Século XXI: o dicionário da língua portuguesa. Rio de Janeiro: Nova Fronteira, 1999. p. 2087 Apud SANTOS, Ronaldo Lima dos. Teoria das normas coletivas. $2^{\text {a }}$ ed., São Paulo: LTr, 2009. p. 105.

${ }^{114}$ Nesse sentido, COMPARATO, Fabio Konder. A afirmação histórica dos direitos humanos. São Paulo: Saraiva, 2003. p. 25 Apud SANTOS, Ronaldo Lima dos. Op. cit., p. 105.

115 SANTOS, Ronaldo Lima dos. Op. cit., p. 105-107.

${ }^{116}$ KANT, Immanuel. A metafísica dos costumes. Trad. Edson Bini. São Paulo: Edipro, 2003. p. 62-63 Apud SANTOS, Ronaldo Lima dos. Op. cit., p. 106.

${ }^{117}$ Destaque-se o seguinte trecho de sua obra: "Essa distinção singular vem à tona no discurso e na ação. Através deles, os homens podem distinguir-se, ao invés de permanecerem apenas diferentes; a ação e o discurso são os modos pelos quais os seres humanos se manifestam uns aos outros, não como meros objetos 
No plano jurídico, a vontade é destacada como um - ou, um dos, dependendo da teoria adotada - elemento(s) fundamental(is) do negócio jurídico: sua manifestação, por meio de atos ou declarações, tem o condão de produzir determinados efeitos jurídicos, criando, modificando ou extinguindo relações jurídicas. Com base nisso, a doutrina civilista formulou várias teorias sobre a natureza do negócio jurídico, as quais explicam, cada uma a sua maneira, o papel da vontade no campo das relações contratuais. $^{118}$

Embora não haja aqui espaço para o estudo aprofundado de todas essas teorias, a análise de alguns de seus fundamentos auxilia na compreensão adequada do papel da vontade no campo das relações contratuais. Nesse sentido, destaque-se a teoria geral dos negócios jurídicos formulada pelo italiano Emílio Betti - não obstante mencionar antecipadamente o conceito de "autonomia privada", o qual somente será abordado após a análise do conceito de autonomia da vontade.

Ao formular sua teoria perceptiva sobre os negócios jurídicos, Emílio Betti discorda da qualificação de negócio jurídico como declaração de vontade,

físicos, mas enquanto homens. Esta manifestação, em contraposição à mera existência corpórea, depende da iniciativa, mas trata-se de uma iniciativa da qual nenhum ser humano pode abster-se sem deixar de ser humano. Isto não ocorre com nenhuma outra atividade da vita activa (Cf. ARENDT, Hannah. A condição humana. Trad. Roberto Raposo. $10^{\mathrm{a}}$ ed., Rio de Janeiro: Forense, 2009. p. 189).

118 Além da teoria perceptiva, de Emilio Betti, outras teorias foram formuladas sobre a definição de negócio jurídico, sendo as principais: o dogma da vontade - em relação ao qual se contrapõe a teoria perceptiva, a teoria da declaração e a teoria da confiança. Desenvolvida por Savigny e Windscheid, e adotado pelo Código Civil francês de 1804, o dogma da vontade considera a vontade como elemento central do negócio jurídico; como fato interior e invisível, a vontade precisa de um sinal exterior que a revele, a exemplo da declaração, com a qual estabelece uma relação não acidental, mas natural. Já a teoria da declaração, cuja formulação completa é atribuída a Büllow, foi adotada pelo Código Civil alemão de 1896 (BGB), apoiando-se, fundamentalmente, na prevalência da declaração sobre a vontade: pouco importa que a declaração corresponda exatamente ao querer interno, traduzindo-lhe, fielmente, o conteúdo - a vontade é apenas causa e não um dos elementos constitutivos do negócio jurídico. Tanto a teoria de Emílio Betti, como a teoria da confiança, desenvolvida por Grotius e irradiada pelos juristas alemães, na segunda metade do século passado, amenizam os extremismos lançados pelo dogma da vontade e pela teoria da declaração. Segundo a teoria da confiança, a vontade declarada deve prevalecer sobre a vontade interna, vez que o declarante deve arcar com o ônus de confiança que provoca nos outros; se, por outro lado, for sabida a inexistência de concordância, o negócio deve ser considerado nulo, em razão da falta de expectativa digna da tutela, evitando-se favorecer, outrossim, a má-fé da pessoa a quem se dirigiu a aparência da vontade. Com isso, busca-se maior segurança e certeza às relações contratuais, de sorte que, os contraentes de boa-fé têm direito a considerar firme a declaração que se podia admitir como vontade efetiva da outra parte, ainda que esta houvesse errado de boafé ao declarara a própria vontade. A teoria da confiança foi adotada por muitos ordenamentos, como o Código Civil português de 1867 e o Código Civil italiano de 1942 (Cf. FRANÇA, Pedro Arruda. Contratos atípicos. $3^{\mathrm{a}}$ ed., Rio de Janeiro: Forense, 2000. p. 3-6). No Código Civil brasileiro, influenciado, na sua primeira versão, de 1916, pelo Código Civil francês, de 1804, verifica-se a predominância do dogma da vontade, como no teor do artigo 112, "Nas declarações de vontade se atenderá mais à intenção nelas consubstanciada do que ao sentido literal da linguagem", em que se repete a regra do artigo 85, da lei anterior. Contudo, não se verifica a contemplação exclusiva dessa teoria, ao prever a delimitação da vontade das partes negociantes, pela observância do princípio da boa-fé e pela necessidade de garantir a segurança das relações jurídicas, conforme o art. 113, segundo o qual "Os negócios jurídicos devem ser interpretados conforme a boa-fé e os usos do lugar de sua celebração." 
como propõe o dogma da vontade. Segundo o autor italiano, a vontade constitui-se em um fato psicológico meramente interno, incompreensível e incontrolável em si mesmo. Apenas na medida em que se torna reconhecível no ambiente social, quer por declarações, quer por comportamentos, a vontade passa a ser considerada um fato social, suscetível de interpretação e de valoração pelo direito. ${ }^{119}$

O acréscimo da expressão "de vontade" em "declaração de vontade", de acordo com o pensamento de Emílio Betti, não passa, com frequência, de uma redundância incolor e inútil, ocupando o lugar de expressão mais específicas e apropriadas, tais como "declaração de aceitação", "declaração de adesão", "de renúncia", "de oferta" e assim sucessivamente, que dizem respeito, propriamente, ao objeto ou conteúdo do querer. Confunde-se, portanto, a vontade entendida como faculdade psíquica, como fato psicológico interno, e a vontade como objeto ou conteúdo do querer.

Para Emílio Betti, a declaração e, consequentemente, o próprio negócio jurídico, não podem ser concebidos com o único e exclusivo papel de revelar um fato psíquico interno, em detrimento do papel de constituir e dar vida a um preceito resultante da autonomia privada das partes. A vontade configura-se como entidade em si mesma, que, conservando-se superior em relação à declaração, encontra nesta apenas um meio de revelação, como a alma em relação ao corpo. ${ }^{120}$

O dogma da vontade leva a crer, conforme o autor italiano, na onipotência da vontade individual, a qual, no foro íntimo da consciência, não encontra limites extrínsecos. Com isso, induz ao desconhecimento dos múltiplos limites sociais e jurídicos que incidem sobre a autonomia privada das partes. Ademais, leva a pensar na possibilidade de evocação de diferentes intenções dos indivíduos que não tenham sido declaradas ou manifestadas com clareza.

O dogma da vontade altera, ainda, os rumos da interpretação dos negócios jurídicos. Em primeiro lugar, obriga à investigação da "vontade interna", mesmo que mantida no estado de intenção oculta ou nutrida apenas por uma das partes, para somente depois ser verificado se a declaração tornou a vontade manifesta, ou se ela está realizada no comportamento ou era compartilhada pela contraparte. $\mathrm{Na}$ esteira desse raciocínio, quando, a partir da declaração ou do comportamento não seja possível demonstrar a "vontade interna" correspondente, ou quando o direito imponha que se

\footnotetext{
${ }^{119}$ BETTI, Emílio. Op. cit., p. 89.

${ }^{120}$ Ibidem, p. 96.
} 
deduza um preceito complementar em relação ao que se fixou explicitamente a partir de certos detalhes típicos, por via de integração ou reconstrução hipotética, , o dogma da vontade induz a postular uma "vontade tácita", "marginal", "presumida" ou "presumível". Além disso, para que a "vontade" tenha vigor, deve poder ser sustentada por pessoa viva e capaz, o que não ocorre, por exemplo, no testamento e nos casos de incapacidade sobrevinda depois da emissão da declaração (com a proposta), mas antes da conclusão do negócio jurídico (contrato). ${ }^{121}$

Com base nesses preceitos, Emílio Betti consolida o seguinte entendimento sobre o papel da vontade nos negócios jurídicos: como fato psíquico interno, a vontade se esgota com a declaração e com o comportamento, sendo por eles absorvida como expressão da autonomia privada, esta sim considerada o principal elemento das relações contratuais.

Toda essa construção teórica parte da constatação, muito importante para a real compreensão de seu alcance, de que, no âmbito jurídico, a vontade pode ter vários sentidos. Para Emílio Betti, aqueles que se servem do termo incautamente, sem lhe notar a ambiguidade, são levados a concluir que é desnecessária a formulação adequada do preceito da autonomia privada, uma vez que apenas o querer é suficiente. Tal conclusão é equivocada, pois, quando se tem o encargo de declarar, contextualmente, que se realize esta ou aquela operação jurídica (compra, venda, empréstimo etc.), simplesmente dizer que se "quer" gera a errônea impressão de que não se conclui um contrato definitivo, tratando-se apenas de uma promessa de realização do negócio jurídico.

Efetivamente, no negócio jurídico, se a vontade, como fato psicológico interno, fosse o elemento decisivo, não haveria razão para manter negócios jurídicos não fundamentados em vontade idônea ou isenta de vícios ou somente anulá-los após reação da parte interessada. ${ }^{122}$ Embora, pela lógica, não se admita um querer e não

\footnotetext{
${ }^{121}$ BETTI, Emílio. Op. cit., p. 97-99.

${ }^{122}$ O Código Civil prevê várias dessas hipóteses, em que é possível a anulação do negócio jurídico: $\boldsymbol{A r t . ~} 138$. São anuláveis os negócios jurídicos, quando as declarações de vontade emanarem de erro substancial que poderia ser percebido por pessoa de diligência normal, em face das circunstâncias do negócio por vício; (...) Art. 145. São os negócios jurídicos anuláveis por dolo, quando este for a sua causa. (...) Art. 171. Além dos casos expressamente declarados na lei, é anulável o negócio jurídico: I - por incapacidade relativa do agente; II - por vício resultante de erro, dolo, coação, estado de perigo, lesão ou fraude contra credores. (...)Art. 214. A confissão é irrevogável, mas pode ser anulada se decorreu de erro de fato ou de coação. (...) Art. 849. A transação só se anula por dolo, coação, ou erro essencial quanto à pessoa ou coisa controversa. (...)Art. 1.550. É anulável o casamento: I - de quem não completou a idade mínima para casar; II - do menor em idade núbil, quando não autorizado por seu representante legal; III - por vício da vontade, nos termos dos arts. 1.556 a 1.558; IV - do incapaz de consentir ou manifestar, de modo inequívoco, o consentimento; $V$
} 
querer simultâneos, é perfeitamente possível que uma pessoa tome uma decisão e emita um comando ao invés de outro, sem a vontade sincera de estar vinculado ou de vê-lo executado, ou mesmo sem o conhecimento preciso de sua declaração, como ocorre nos casos de simulação e erro, assim como ao subscrever um documento de negócio sem prévia leitura. $^{123}$

Com efeito, a crítica de Emílio Betti ao dogma da vontade não incide sobre o caráter de "ato de vontade" que um negócio convencional deve ter, mas sim sobre a função atribuída à vontade e sobre a posição que esta deve ocupar na estrutura do negócio jurídico, em concurso com outros elementos, tendo em vista seu tratamento jurídico. ${ }^{124}$ A partir dela e, independentemente de sua adoção pelo ordenamento pátrio, adquire-se a consciência de sua importância na constituição do ato jurídico, visto ser sua manifestação capaz de produzir determinados efeitos jurídicos, como criar, modificar ou extinguir relações.

\subsection{Autonomia da vontade}

A autonomia da vontade consiste em um princípio segundo o qual os indivíduos têm liberdade para criar relações na órbita do direito, desde que se submetam às regras impostas pela lei, e que seus fins estejam em conformidade com o interesse geral. Trata-se, portanto, não somente de um elemento de liberdade geral, mas também de liberdade jurídica, correspondente ao poder insuprimível atribuído ao homem de criar situações jurídicas, por atos de vontade. ${ }^{125}$ De acordo com Martinho Garcez Neto, referido princípio pode ser resumido na seguinte afirmação: "o homem é dotado de vontade livre e esta vontade livre pode criar direitos e obrigações." 126

O princípio da autonomia da vontade tem origem remota no direito canônico, que tanto se esforçou para arraigar profundamente na consciência humana o respeito à palavra empenhada, independentemente da forma material de expressão da

- realizado pelo mandatário, sem que ele ou o outro contraente soubesse da revogação do mandato, e não sobrevindo coabitação entre os cônjuges; VI - por incompetência da autoridade celebrante.

${ }^{123}$ BETTI, Emílio. Op. cit., p. 108-113.

${ }^{124}$ Ibidem, p. 107.

${ }^{125}$ SANTOS, Ronaldo Lima dos. Op. cit., p. 110.

126 Autonomia da vontade. In SANTOS, J. M. de Carvalho Santos; DIAS, José de Aguiar (coord.). Repertório enciclopédico do direito brasileiro. V. V, Rio de Janeiro: Editor Borsoi, 1947. p. 195. 
vontade. Para os canonistas, a palavra dada conscientemente criava uma obrigação de caráter moral e jurídico para o indivíduo. Mais do que isso, ensejava a proteção divina da obrigatoriedade dos contratos. Portanto, para ter força vinculante, a vontade deveria ser puramente declarada. A escola de direito natural e os filósofos do século XVIII apenas incrementaram a ideia que, pouco tempo depois, foi consagrada pela legislação revolucionária, como princípio básico do novo sistema político e social inaugurado. ${ }^{127}$

$\mathrm{Na}$ filosofia, identificam-se duas grandes teorias em torno da autonomia da vontade humana: a do livre-arbítrio e a do determinismo. A primeira revela o livre poder de autodeterminação da vontade. A segunda concebe o movimento volitivo como algo estranho ao controle do indivíduo, sendo ele ditado pela energia do universo (determinismo mecânico), pelos instintos, inclinações e sentimentos do ser humano (determinismo fisiológico), ou pelas ideias, pensamentos ou raciocínio (determinismo psicológico). ${ }^{128}$

Kant e Hegel, por exemplo, inspiram-se no livre-arbítrio. Para o primeiro, o livre-arbítrio é determinado pela razão pura, marcando a independência do ser em relação aos impulsos sensíveis ou estímulos, que caracterizam o arbítrio animal. As ações são determinadas pela vontade pura, limitadas apenas por fatores internos e externos, com o objetivo de garantir a conformidade com a liberdade do outro. Kant define a autonomia da vontade nas seguintes palavras:

Autonomia da vontade é aquela sua propriedade graças à qual ela é para
si mesma a sua lei (independentemente da natureza dos objectos do
querer). O princípio da autonomia é portanto: não escolher senão de
modo a que as máximas da escolha estejam incluídas simultaneamente,
no querer mesmo, como lei universal. Que esta regra prática seja
imperativo, quer dizer que a vontade de todo o ser racional esteja
necessariamente ligada a ela como condição, é coisa que não pode
demonstrar-se pela simples análise dos conceitos nela contidos, pois se
trata de uma proposição sintética; teria que passar-se além do
conhecimento dos objectos e entrar numa crítica do sujeito, isto é da

127 GARCEZ NETO, Martinho. Op. cit., p. 196.

${ }^{128}$ SANTOS, Ronaldo Lima dos. Op. cit., p. 108. 
razão prática pura; pois esta proposição sintética, que ordena apodicticamente, tem que poder reconhecer-se inteiramente $a$ priori. ${ }^{129}$

Imprimindo conotação diferente ao livre-arbítrio e abandonando a concepção negativista de abstenção de Kant para acrescentar uma dimensão positiva da vontade, Hegel vê no acordo de vontades entre os indivíduos expressão da verdadeira liberdade, sendo o campo contratual propício para tanto. Segundo seu entendimento, a relação contratual seria fruto do livre-arbítrio das partes, encerrando uma união de vontades distintas que, em viés oposto, conservam sua identidade ao mesmo tempo em que perdem o que possuem de diferente e distinto ao se unirem. ${ }^{130}$ Trata-se da vontade como expressão do ser humano na regulação de seus próprios interesses, ou seja, como fonte produtora de direitos e obrigações.

Juridicamente, autonomia da vontade implica liberdade contratual, a qual se apresenta em três acepções distintas: 1) liberdade de celebrar ou não o contrato; 2) liberdade de seleção do tipo contratual; e 3) liberdade de negociar livremente o conteúdo do contrato.

Na primeira acepção, a liberdade contratual é tomada em seu mais estrito sentido, significando a liberdade que toda pessoa tem de celebrar ou não um contrato - ninguém deve, em princípio, ser forçado a vincular-se contratualmente, participando, contra sua vontade, de uma relação contratual. Na segunda acepção, implica a liberdade, conferida aos particulares, de escolha do tipo contratual que seja mais adequado para a satisfação de seus interesses. Por fim, a terceira acepção revela o poder atribuído às partes de, por si, regularem todas as condições e modalidades de seus compromissos, de decidirem, sozinhas e sem tutela legal, sobre a matéria e o alcance de suas convenções.

Destaque-se que a liberdade contratual, no sentido amplo, apenas se materializa por meio de uma vontade eminentemente jurídica, livre de vícios ou defeitos que possam anulá-la, não se tratando apenas de uma aptidão natural de querer, fazer ou realizar, e sim de uma vontade abstrata e potencial, reconhecida ou atribuída pelo ordenamento como juridicamente válida. Disso resulta a possibilidade de conflitos

${ }^{129}$ KANT, Immannuel. Fundamentações da metafísica dos costumes. Trad. Paulo Quintela. Lisboa: | Edições 70, 1997. p. 85 Apud RODRIGUES JUNIOR, Otavio Luiz. Op. cit., p. 117.

${ }_{130}$ HEGEL, George Wilhem Friedrich. Princípios da filosofia do direito. Trad. Orlando Vitorino. São Paulo: Martins Fontes, 2003. p. 31 Apud SANTOS, Ronaldo Lima dos. Op. cit., p. 109. 
ocasionados pela divergência entre vontade manifestada e vontade efetiva, os quais deverão ser solucionados pelo legislador ou pelo órgão julgador, com base na maior ou menor relevância atribuída às duas espécies de vontade, além da ponderação de dados concretos da realidade. ${ }^{131}$

\subsection{Autonomia privada}

A autonomia privada consiste no poder de criação de regras, pelos próprios indivíduos, para si mesmos, independentemente do poder público, como ocorre em um contrato. Embora normalmente relacionada a pessoas no papel de sujeitos contratuais, remetendo à esfera do direito privado, fala-se em autonomia privada também na esfera do direito público, como ocorre em relação a um tratado internacional, cuja formulação e execução das regras concentram-se nos Estados convenentes. ${ }^{132}$ Como se vê, no cerne da questão está o poder de autorregulamentação, com a criação e aplicação de normas em favor dos próprios interesses. ${ }^{133}$

A autonomia privada contrapõe-se à heteronomia, segundo a qual as regras são criadas não pelo sujeito interessado, sobre o qual elas se aplicam, e sim por sujeito estranho, provido de poder público. É o que ocorre com a lei, os regulamentos administrativos e as decisões judiciais, considerados típicos atos de heteronomia, porque proveem de sujeitos que possuem o poder de regular aqueles interesses, independentemente da vontade de seu titular. ${ }^{134}$

As lições de Ronaldo Lima dos Santos delimitam com clareza os contornos da autonomia privada, utilizando, como contraponto, a noção de liberdade contratual, implícita no princípio da autonomia da vontade:

\footnotetext{
131 Nessa discussão, rememoram-se as teorias civilistas acerca dos negócios jurídicos. Em relação a elas, Ronaldo Lima dos Santos afirma que a doutrina, em geral, parece caminhar para a adoção de uma posição intermediária, especialmente no tocante ao prestígio da vontade em detrimento da declaração, e vice-versa. Citando Darcy Bessone, esclarece que a regra é dar-se preferência à vontade real; contudo, há casos em que, para garantir a segurança das relações jurídicas, deve prevalecer a vontade declarada e a boa-fé dos que nela confiaram (Cf. OLIVEIRA, Darcy Bessone de. Do contrato. Rio de Janeiro: Forense, 1960. p. 45 Apud SANTOS, Ronaldo Lima dos. Op. cit., p. 109).

${ }^{132}$ SANTOS, Ronaldo Lima dos. Op. cit., p. 112.

${ }^{133}$ Nesse sentido, Emílio Betti define a autonomia da vontade como sendo "atividade e potestas, criadora, modificadora ou extintora de relações jurídicas entre particulares: relações cuja vida e cujas vicissitudes, são, antecipadamente, disciplinadas pelas normas jurídicas preexistentes" (Cf. Op. cit., p. 81).

134 PERLINGIERI, Pietro. Autonomia negoziale e autonomia contratuale. $2^{\text {a }}$ ed., Napoli: Edizioni Scientifiche Italiane, 2000. p. 327 Apud SANTOS, Ronaldo Lima dos. Op. cit., p. 113.
} 
Ela não se apresenta como um simples direito subjetivo do indivíduo.

Exercer um direito é ativar as faculdades que lhes são inerentes; o direito e as faculdades dele correspondentes derivam de uma norma que os precede; no ato de autonomia privada, por sua vez, a norma lhe é posterior, pois resulta do exercício do poder. A norma resulta do conteúdo da autonomia privada. Autonomia privada e direito subjetivo são conceitos distintos, com manifestação em momentos diversos. ${ }^{135}$

Para Walküre Lopes Ribeiro da Silva, como poder de criar normas jurídicas, o conceito de autonomia privada encontra fundamento na teoria normativista de Kelsen, segundo a qual o ordenamento jurídico é representado por uma pirâmide, cujo vértice é ocupado pela norma fundamental - pressuposto lógico de validade de unidade de todo o sistema -, enquanto a base é ocupada pela norma individualizada, que pode ser exemplificada tanto pelo contrato, quanto pela sentença individual. Disso decorre que, ao menos no se que se refere à autonomia privada individual, cujo espaço de atuação da autonomia privada é delimitado pelas normas estatais, consideradas sua fonte de validade, pode-se falar em um poder normativo derivado. ${ }^{136}$

Destaque-se que a principal manifestação da autonomia privada ocorre no âmbito dos negócios jurídicos; contudo, a doutrina civilista moderna aponta que, atualmente, ela também é decisiva em outros campos, relacionados às mais diversas esferas existenciais do ser humano, conforme esclarece Francisco dos Santos Amaral Neto:

Seu campo de realização é, por excelência, o direito das obrigações, no qual o contrato é lei, nas diversas espécies que a liberdade contratual permite estabelecer, sendo crescente a sua presença nos contratos administrativos, no direito da economia e da concorrência, nos tratados e convenções internacionais e na instituição de juízo arbitral. No direito

\footnotetext{
${ }^{135}$ SANTOS, Ronaldo Lima dos. Op. cit., p. 115.

136 Segundo a autora, embora a autonomia privada individual possa ser considerada poder normativo derivado, no âmbito coletivo, a autonomia privada configura poder normativo originário, seja por suas origens, vez que o Estado não o conferiu aos particulares, mas somente reconheceu sua existência, seja quanto ao seu exercício, pois são previstos critérios autônomos de representação, procedimento, competência etc.; ressalta, outrossim, que ao exercitar a autonomia privada coletiva, os atores sociais apenas interagem com o ordenamento jurídico estatal, promovendo a renovação deste ao defender a relevância da ação e dos interesses coletivos (Cf. Op. cit., p. 211-212).
} 
sucessório realiza-se no testamento, negócio jurídico com que a pessoa dispõe de seus bens ou estabelece outras prescrições para depois da sua morte. ${ }^{137}$

Nesse sentido, Taisa Maria Macena de Lima aponta as razões que justificam essa expansão:

O princípio da autonomia privada justifica a resistência do indivíduo à intromissão do Estado no espaço que deve ser só seu, a na legítima tentativa de ser feliz. Por isso mesmo, a autonomia privada assume novas dimensões, como a luta pelo direito à resignação sexual, o reconhecimento de diferentes modelos de família (matrimonial, nãomatrimonial, monoparental, etc.), o modelo de filiação voltado antes para a paternidade socioafetiva do que para a paternidada apenas biológica, a união homoafetiva, entre outros. ${ }^{138}$

Por fim, nas lições de Jorge Cesa Ferreira da Silva, fica claro como a autonomia privada alterou, inclusive, as configurações do direito de família:

Muito embora o direito obrigacional seja o espaço por excelência da autonomia privada, sobretudo na órbita negocial, é também inegável que o direito de família vem dando excelentes exemplos da noção desse princípio. De há muito, homens e mulheres convivem familiarmente sem casamento, pelos mais diversos fatores, sejam eles lícitos ou não. Contudo, por longa data, aos relacionamentos não provenientes de casamento não era dada a chancela civil, a força normativa portanto. Hoje, trata-se de livre escolha dos parceiros manterem vínculos nascidos

${ }^{137}$ AMARAL NETO, Francisco dos Santos. Op. cit..

${ }^{138}$ A nova contratualidade ma reconstrução do direito privado nacional. Revista Virtuajus. Belo Horizonte, ano $3, \quad$ n. $1, \quad$ jul.2004, Disponível em: <http://www.fmd.pucminas.br/Virtuajus/virtuajus_inicio.html>. Acesso em: 01/09/2011. 
do casamento ou da mera convivência. Em qualquer escolha, a força normativa correspondente à eficácia reconhecida, é garantida. ${ }^{139}$

A autonomia privada não se reduz, portanto, à iniciativa econômica ou à autonomia contratual em sentido estrito; ao contrário, como poder de criar regras para si mesmo, a autonomia privada incide decisivamente em matérias de cunho eminentemente objetivo, relacionados desde a proteção da própria pessoa em si mesmo considerada, até as relações interpessoais de caráter não econômico, na esfera familiar. Como retratado por Roberta Elzy Simiqueli de Faria, o princípio da autonomia privada, em um sistema de liberdade, "é essencial para a convivência social e tem de estar consagrado a percorrer todos os domínios da atividade humana, não apenas o econômico". ${ }^{40}$

\title{
4.5. Relação entre autonomia privada e autonomia da vontade
}

Parte da doutrina contemporânea utiliza as expressões "autonomia da vontade" e "autonomia privada" como sinônimas, normalmente em referência à faculdade atribuída às partes de regulamentar seus próprios interesses, conforme entendimento abaixo transcrito, extraído de artigo redigido por Fabíola Santos Albuquerque:

\begin{abstract}
A esse respeito, afirmamos nosso entendimento de absoluta indistinção entre autonomia privada, de um lado, e auto-regulamento e autonomia da vontade, de outro. Para alguns, autonomia privada capta o momento jurídico de exteriorização da vontade, sendo esta, enquanto intenção íntima, uma instância pré-jurídica. Para outros, autonomia evoca significação normativa e não podem os particulares ser autores de normas jurídicas, diante do monopólio legislativo do Estado. Essas distinções são inócuas e procuram escapar, sem sucesso, à origem e à natureza políticas
\end{abstract}

${ }^{139}$ Princípios de direitos das obrigações no novo Código Civil. In SARLET, Ingo Wolfgang. O novo Código Civil e a Constituição. Porto Alegre: Livraria do Advogado, 2003. p. 99-126 Apud FARIA, Roberta Elzy Simiqueli de., Op. cit., p. 64.

${ }^{140}$ Roberta Elzy Simiqueli de., Op. cit., p. 63. 
que se imputam à autonomia privada (ou da vontade) ou ao caráter imperativista que se atribuiu à vontade. ${ }^{141}$

Contrariando esse entendimento, Ronaldo Lima dos Santos aponta que, conquanto sejam próximas, tais expressões não se confundem, enunciando fenômenos jurídicos distintos. ${ }^{142}$ No mesmo sentido, Francisco dos Santos Amaral Neto esclarece que:

[...] autonomia privada é o poder jurídico dos particulares de regularem, pelo exercício de sua própria vontade, as relações de que participam, estabelecendo o seu conteúdo e a respectiva disciplina jurídica. Por muitos considerado como sinônimo de autonomia da vontade, com ela, a meu ver, não se confunde, pois a expressão 'autonomia da vontade' tem uma conotação subjetiva, psicológica, enquanto 'autonomia privada' significa o poder particular de criar relações jurídicas de que se participa. Assim, é o poder que nós, particulares, temos, de regular juridicamente as nossas relações, dando-lhes conteúdo e eficácia juridicamente reconhecidos. ${ }^{143}$

Por sua feição subjetiva, a autonomia da vontade está ligada à formação e manifestação da vontade com vistas à prática de um ato jurídico; por sua vez, a autonomia privada marca o poder dessa mesma vontade de modo objetivo, real e concreto, criando normas jurídicas com conteúdo e eficácia juridicamente reconhecidos. Em outras palavras, uma é a faculdade, outra, o poder.

Com base nessa distinção, afirma-se que o contrato, como expressão da autonomia da vontade, consiste em um fenômeno exclusivamente volitivo, cuja formação varia de "dentro para fora". Da ótica da autonomia privada, ele alcança concretude no mundo real, passando a vontade a ser condicionada por fatores exteriores a ela, que dizem respeito aos motivos contratuais. ${ }^{144}$ Quando as expressões são utilizadas de

${ }^{141}$ ALBUQUERQUE, Fabíola Santos. Liberdade de contratar e livre iniciativa. Revista Trimestral de Direito Civil. Rio de Janeiro, ano 4, v. 15, p. 73-88, jul.-set.2003, p. 76 Apud Roberta Elzy Simiqueli de., Op. cit., p. 60.

${ }_{142}^{142}$ SANTOS, Ronaldo Lima dos. Op. cit., p. 118.

143 Autonomia privada. Revista do CJF, Brasília, n. 09, set.-dez.1999. Disponível em: <www.cjf.gov.br/revista/numero9/artigo5.htm>. Acesso em: 01/09/2011.

${ }^{144}$ FARIA, Roberta Elzy Simiqueli de. Op. cit., p. 61-62. 
maneira imprecisa e indiscriminada, os autores restringem-se a afirmar ser o contrato fruto da manifestação da autonomia - sem acrescentar, portanto, qualquer qualificação ao vocábulo.

De acordo com tal entendimento, a autonomia da vontade é, na verdade, pressuposto da autonomia privada. Isso porque, como poder normativo, a primeira manifestação do preceito de autonomia privada corresponde à externalização da vontade, por meio da declaração ou do comportamento, adquirindo, posteriormente, existência própria, como entidade duradoura e desprendida de seu autor, de modo a operar efeitos para o futuro independentemente da vontade que o tenha originado.

Além desses dois entendimentos, opostos entre si, identificam-se, ainda, outras linhas de pensamento: uma, que considera a autonomia privada como mera adaptação da autonomia da vontade, e outra, que fala em "autonomia privada da vontade".

Na primeira delas, o conceito de autonomia da vontade teria sido formulado no século XIX, após o sucesso da Revolução Francesa e a consolidação dos ideais de igualdade, fraternidade e liberdade. Tendo os homens nascidos livres e iguais, era indispensável reconhecer-lhes a liberdade de criar e produzir direitos, por meio do que se convencionou chamar autonomia da vontade.

De acordo com Antonio Junqueira de Azevedo, essa concepção da autonomia da vontade, ligada à noção de liberdade ou de possibilidade conferida a cada pessoa para agir ou não agir, de um modo ou de outro, foi denominada "francesa", em homenagem às suas raízes. Trata-se, na realidade, da vontade individual - com concepção fática - sendo autorizada pelo ordenamento jurídico. Ainda segundo referido autor, tal concepção traz, em si, o gérmen de sua própria destruição:

[...] tratar-se-ia, na verdade, de um poder jurídico, isto é, autorização dada previamente pelo ordenamento, para que o indivíduo, respeitadas as regras legais, dê causa, por meio do negócio jurídico, a efeitos jurídicos. ${ }^{145}$

145 AZEVEDO, Antônio Junqueira de. Ciência do direito, negócio jurídico e ideologia. In: DI FRANCESCO, José Roberto Pacheco. Estudos em homenagem ao professor Silvio Rodrigues. São Paulo: Saraiva, 1989. p. 15 Apud RODRIGUES JUNIOR, Otavio Luiz. Op. cit., p. 119. 
Segundo essa corrente de pensamento, a autonomia, qualificada simplesmente como produto da vontade, seria resultado de uma visão reducionista do individualismo, que deixa de lado o substrato humanista. No século XX, ela se aproximou dos princípios contratuais e foi tomada como sinônimo de liberdade contratual, em razão do que passou a sofrer duras críticas, especialmente no sentido de que lhe fossem impostos limites. Foi neste contexto que Emilio Betti, por exemplo, proclamou que a autonomia sob a égide da vontade põe a perder a correta visão do negócio jurídico, o qual não poderia consagrar uma faculdade de "querer" no vácuo, como propunha o individualismo. Em razão disso, era necessária a reformulação do conceito.

Com o término da $1^{\text {a }}$ Guerra Mundial e a propagação de novos ideais, contrários ao individualismo reinante no século anterior, as novas estruturas sociais e econômicas passaram a reclamar um Estado intervencionista, arrastando para a queda as estruturas formais do direito privado então vigente, como relatam Orlando Gomes e Antunes Varela:

[...] Aquele direito privado que fizera do contrato o instrumento por excelência da vida econômica e a expressão insubstituível da autonomia privada, e, da propriedade, um direito natural do homem sobre o qual se apoiaria a vida econômica da sociedade e dele próprio, não mais existe onde já se implantou a nova economia coordenada e dirigida pelo Estado. Ele se fragmenta e cede terreno ao direito econômico. [...] O direito econômico compreende as normas relativas às relações econômicas, estejam no corpo do direito civil, do código comercial ou em leis específicas, sejam de direito privado ou público, integrem este ou aquele ramo da árvore jurídica. ${ }^{146}$

Otavio Luiz Rodrigues Junior aponta que, com resultado dessas mudanças, teria surgido uma nova visão da autonomia da vontade, tão própria que, repudiando o termo "vontade", colocou em evidência a partícula privada. ${ }^{147}$ Assim, ao contrário do entendimento que reconhece distinções, mas também coexistência das expressões no mundo jurídico, fala-se, por ora, na substituição e no esvaziamento de

${ }^{146}$ GOMES, Orlando; VARELA, Antunes. Direito econômico. Rio de Janeiro: Forense, 1977. p. 23 Apud RODRIGUES JUNIOR, Otavio Luiz. Op. cit., p. 121.

${ }^{147}$ RODRIGUES JUNIOR, Otavio Luiz. Op. cit., p. 121. 
sentido da expressão autonomia da vontade pela expressão autonomia privada, conforme se depreende do seguinte trecho da obra de Luigi Ferri:

Tutto questo spiega l'imprecisione e il promiscuo uso delle espressioni "autonomia privata", "autonomia della volontá", "liberta contrattuale", ecc., che ho ora rilevato; ma spiega soprattutto la nessuna utilità costruttiva del concetto di autonomia privata cosi configurato. (...) Ed infatti non vi sarebbe attività umana volontaria che non possa essere fatta rientrare in uma tal concezione dell'autonomia privata (ad esclusione dell'attività attribuile allo Stato ed aglia enti pubblici in generali). ${ }^{148}$

Explica Otavio Luiz Rodrigues Junior que o surgimento da autonomia da vontade como princípio jurídico teria sido a "resposta que a Civilização Ocidental soube dar a anseios seculares de igualdade e liberdade." ${ }^{149}$ Com as mudanças econômicas, sociais e políticas do século XX, passa-se a reclamar um conceito de autonomia desvinculado dos postulados liberais da autonomia da vontade, portanto, mais institucional. Mais do que isso, defende-se a intervenção estatal, legal e judicial, como forma de conter os abusos da liberdade pelos particulares.

Por derradeiro, também no século XX foi elaborado o conceito, dito social, de "autonomia privada da vontade". Curiosamente, o novo conceito foi construído a partir da observação das práticas comerciais realizadas durante o período mercantilista, nos séculos XV e XVI - casos de navegadores vênetos e cartagineses que realizam negócios com tribos africanas e povos bárbaros. Em tais situações, mesmo sendo indiscutível a falta de juridicidade dos atos praticados, que prescindiam de disposições normativas antecedentes ou de alguma noção prévia de Estado, verificava-se o caráter vinculante, típico dos negócios jurídicos.

Fala-se na "função social do contrato" como preceito destinado a integrar os contratos numa ordem social harmônica, visando impedir tanto aqueles que prejudiquem a coletividade, quanto os que prejudiquem pessoas determinadas. ${ }^{150}$ Tal

${ }^{148}$ FERRI, Luigi. L'autonomia privata. Milano: Giuffrè, 1959, p. 4-5 Apud RODRIGUES JUNIOR, Otavio Luiz. Op. cit., p. 121.

${ }^{149}$ RODRIGUES JUNIOR, Otavio Luiz. Op. cit., p. 123.

${ }^{150}$ Sobre o tema, é emblemática a lição de Clovis Bevilácqua: "Por meio do contracto, o habitante do extremo da Asia ou da Australia e o que vive sob o céo americano, onde brilha a luza branca da estrella 
concepção parte do pressuposto de que todo contrato, amigável, pacífico ou guerreiro, entre pessoas de sistemas jurídicos diferentes, é político; não havia, nesse sentido, como negar relevância jurídica a tais contratos. O poder negocial, nesses casos, não seria fundamentado nem na vontade, nem na lei, mas no caráter social e na utilidade que esse caráter oferece aos homens.

Não obstante as diversas concepções apresentadas, será adotada neste estudo aquela que distingue os conceitos de autonomia da vontade e autonomia privada, tomando uma como a faculdade, e outra, como poder capaz de realizá-la no mundo jurídico. Além disso, cumpre ressaltar que o objetivo do presente trabalho é desvendar os limites da autonomia privada na esfera das relações individuais de trabalho, razão pela qual ela será abordada exclusivamente no âmbito das relações interpessoais, isto é, como autonomia privada individual, em detrimento da autonomia privada coletiva.

A respeito da feição individual da autonomia privada, é oportuno esclarecer, antes de adentrar no capítulo sobre as limitações, que ela se limita à atuação dos particulares, mas não somente nas relações intersubjetivas de configuração simples, isto é, entre somente dois indivíduos, em polos opostos da relação jurídica. É individual, também, o poder de autorregulação atribuído aos particulares nas relações jurídicas plurissubjetivas, isto é, com mais de um indivíduo em um ou em ambos os polos da relação. Importa, nesse aspecto, que os efeitos jurídicos decorrentes do auto-regramento, além de concretos e divisíveis, limitem-se à esfera jurídica de seus destinatários, somente excepcionalmente trazendo benefícios ou prejuízos a terceiros. ${ }^{151}$

polar, ou onde resplandece a constellação do cruzeiro, reconhecem a congruência de seus interesses, associam-se, ainda que momentaneamente, e, sem que jamais se vejam, entram numa cooperação, para o fim de satisfazerem as proprias necessidades. Embora não se conheçam, senão como armazéns de onde se expedem e para onde se dirigem as mercadorias, a confiança se estabelece entre ambos, longa e profunda, facilitando as transacções, centuplicando as energias”. (Cf. BEVILÁCQUA, Clóvis. Direito das obrigações. Rio de Janeiro: Rio de Janeiro, 1977. Edição histórica Apud RODRIGUES JUNIOR, Otavio Luiz. Op. cit., p. 123-124).

${ }^{151}$ SANTOS, Ronaldo Lima dos. Op. cit., p. 120-121. 


\section{LIMITES À AUTONOMIA PRIVADA NO DIREITO DO TRABALHO}

Pregando a liberdade e a igualdade entre os homens, o liberalismo chocou-se frontalmente com a realidade social. A construção teórica sobre a plena autonomia para constituir relações contratuais tornou-se inadequada, passando a coexistir com os andaimes de uma concepção antagônica, relacionada à necessidade de controle do exercício dessa liberdade. ${ }^{152}$

A sociedade reconheceu que os contratos - não apenas o contrato de trabalho - poderiam ser fonte de injustiças, vez que nem sempre os contratantes se encontram em perfeito estado de igualdade: no máximo, poderia haver igualdade jurídica utópica e ideal, em relação à lei -, a qual é desmentida pela desigualdade econômica e social. Sendo os contratos impostos como lei da parte mais forte, cabendo à parte mais fraca apenas aceitá-los, sem possibilidade de discussão ou impugnação de seu conteúdo, demonstrou-se a fraqueza do dogma da liberdade contratual, especialmente entre sujeitos com poder econômico muito diferente.

Para corrigir essa distorção, o Estado passou a intervir na disciplina dos contratos, como relata Sergio Armando Frazão:

O Estado, intervindo, acabou de desprestigiar o que estava consagrado nos códigos, opôs-se a que, com apoio neles, o contrato consagrasse uma situação de injustiça; reconheceu que as convenções livremente discutidas resumiam-se, na realidade, à imposição dos mais fortes e à sujeição daqueles que não tinham como resisti-los. Houve, assim, por bem, limitá-la. Retirou a liberdade de contratar ao que a utilizava como

\footnotetext{
${ }^{152}$ Segundo Maria do Rosário Palma Ramalho, os excessos cometidos em nome do liberalismo econômico e da liberdade contratual, no século XVIII, foram denunciados tanto pela Igreja Católica, quanto pelas emergentes ideologias marxistas. Por meio da Encíclica Rerum Novarum, do Papa Leão XIII, a Igreja Católica apelou pela proteção e dignificação dos trabalhadores; as ideologias marxistas apelaram pelo associativismo sindical como forma de ultrapassar a debilidade negocial dos trabalhadores na estipulação dos contratos de trabalho. Influenciados por tais apelos, na última década do século XIX, diversos Estados, incluindo o Brasil, iniciaram uma intervenção normativa nessa área, pondo termo ao abstencionismo legislativo até então vigente. (Cf. Direito do trabalho - Parte I.... Op. cit., p. 41). No Brasil, por exemplo, o Decreto n. 1.313, de 1891, dispensou proteção específica aos menores nas fábricas da capital federal (Cf. NASCIMENTO, Amauri Mascaro. Curso de direito.... Op. cit., p. 96).
} 
meio de opressão; procurou, impondo certas normas, melhorar as condições do contratante desprotegido. ${ }^{153}$

Especificamente no âmbito das relações de trabalho, exigiu-se que o Estado interviesse nas relações contratuais em favor dos trabalhadores, sob pena de comprometer o futuro da própria sociedade, já que a exploração desumana dos trabalhadores repercutia negativamente sobre as novas gerações. ${ }^{154}$ Assim, com o objetivo de sanear os males causados, corrigindo as desigualdades e evitando que se criassem outras, foi tomando corpo uma legislação específica, por meio da qual o Estado impôs limites além dos quais não poderia avançar a autonomia privada dos sujeitos da relação de emprego. ${ }^{155}$

De acordo com Cesarino Junior, longe de configurar um atentado à liberdade contratual, tais limitações foram criadas com o objetivo de defender a vontade, especialmente a daqueles em condições de inferioridade, sobretudo econômica , mantendo, com isso, o justo equilíbrio potencial entre as partes. Com isso, seria realizada a função social do contrato, reconduzindo a formas pacíficas e equitativas aquelas que são relações de violência e supremacia do mais forte. ${ }^{156}$

$\mathrm{Na}$ verdade, chegou-se a um paradoxo: para melhor proteger o trabalhador individual, foi necessário considerá-lo não como um indivíduo, mas como parte de uma coletividade, estabelecendo-se disposições de ordem pública para regular a relação de trabalho, com o objetivo de anular a posição de inferioridade do trabalhador. Como resultado, o poder normativo atribuído às partes deixou de ser considerado absoluto, conforme lições de Ronaldo Lima dos Santos:

\footnotetext{
${ }^{153}$ (FRAZÃO, Sérgio Armando. Da autonomia da vontade. Rio de Janeiro: Coelho Branco Filho, 1939. p. 79 Apud GARCEZ NETO, Martinho. Op. cit., p. 199.

${ }^{154}$ Sobre os males da exploração da mão-de-obra sobre as novas gerações, Evaristo de Moares Filho reproduziu parte do discurso de Lord Macaulay, na Câmara dos Comuns: "nossos jovens, sobrecarregados de trabalho, se converterão numa raça de homens débeis e ignóbeis, pais de uma prole ainda mais débil e ignóbil" (Cf. MORAES FILHO, Evaristo de. Introdução ao direito do trabalho. V. 1, Rio de Janeiro: Forense, 1956. p. 363-364 Apud SILVA, Walküre Lopes Ribeiro da. Op. cit., p. 216).

${ }^{155}$ Afirma-se, nesse aspecto, que a intervenção estatal não teria sido motivada, unicamente, por objetivos humanitários, relacionados à necessidade de proteção dos trabalhadores. Pregando a liberdade de todos perante a lei e fechando os olhos para a grave questão social, o Estado agia em conformidade com os interesses capitalistas. A difusão da doutrina marxista e, posteriormente, o exemplo da Revolução Soviética, os quais indicavam uma saída revolucionária para a luta de classes, ameaçaram o Estado que, consequentemente, vislumbrou na proteção da classe trabalhadora, a forma de preservar sua própria sobrevivência (Cf. SILVA, Walküre Lopes Ribeiro da. Op. cit., p. 216).

${ }^{156}$ CESARINO JUNIOR, Antonio Ferreira. Natureza jurídica do contrato.... Op. cit., p. 110.
} 
A autonomia privada, assim, não é absoluta. Ela deve ser conciliada com o direito à idêntica quota de liberdade das outras pessoas e com outros valores do Estado Democrático de Direito, como a autonomia pública, a igualdade, a solidariedade e a segurança. A própria idéia de ordenamento jurídico correria riscos se todos viessem com plena e absoluta liberdade. Tal circunstância torna inexorável a intervenção em certos casos, restringindo a autonomia individual, seja para tutela da liberdade dos outros, em conformidade com uma "lei geral de liberdade" - como diria Kant -, seja para favorecer o bem comum e proteger a paz jurídica de toda a sociedade. Essa restrição pode dar-se, inclusive, em função da própria proteção do titular do poder [...]. ${ }^{157}$

Assim, no âmbito das relações de trabalho, o conteúdo do contrato de trabalho foi amplamente moldado pela lei, por meio de normas de ordem pública, cuja maioria apresenta caráter imperativo. Paralelamente à atuação estatal, fortaleceu-se a atividade normativa dos particulares no campo das relações coletivas, fazendo com que parte significativa da relação contratual de trabalho fosse moldada por instrumentos de regulamentação coletiva, cujas cláusulas apenas podem ser afastadas pelas partes para disporem em sentido mais favorável ao trabalhador. Como resultado, a liberdade de estipulação das partes no nível do contrato individual de trabalho foi restringida, não obstante o caráter privado do contrato e do próprio direito do trabalho. ${ }^{158}$

A ordem pública, a despeito do atual peso dos instrumentos coletivos na regulamentação das condições de trabalho, é, sem dúvida, o principal instituto de regulamentação e limitação da autonomia privada dos particulares nas relações de trabalho. Por essa razão, o estudo do tema dos limites à negociação no contrato individual de trabalho exige perfeita compreensão do que seja a ordem pública, tanto da ideia central que fundamenta o instituto, quanto dos contornos e conteúdo específicos que assume no âmbito do direito do trabalho.

\subsection{A ordem pública como a primeira fonte de limitações}

\footnotetext{
${ }^{157}$ Op. cit., p. 116.

${ }^{158}$ RAMALHO, Maria do Rosário Palma. Direito do trabalho - Parte II - Situações laborais individuais. $3^{\text {a }}$ ed., Coimbra: Almedina, 2010. p. 221.
} 
A afirmação da supremacia da ordem pública no Estado Democrático de Direito está presente na totalidade das obras jurídicas; entretanto, poucos autores preocupam-se em delimitar os contornos do instituto, partindo do pressuposto de que os destinatários de obras jurídicas têm conhecimentos precisos a respeito do tema, o que nem sempre corresponde à realidade. Apesar da aparente obviedade, a ordem pública revela-se em um dos institutos mais controvertidos do universo jurídico, sendo que sua análise exigiu de juristas de diferentes épocas e localidades profundas reflexões, encontros, desencontros e duros enfrentamentos doutrinários, desde que a expressão "ordem pública" foi utilizada pela primeira vez no Código Civil de Napoleão.

Segundo Mario Garmendia Arigón, a expressão provém do direito romano, no qual, com certas variações, diversas normas do Digesto repetiam a máxima de Ulpiano "privatorum convention juri publico non derogat": convenções entre particulares não derrogam o direito público. Todavia, o processo de tradução da língua latina teria sido acometido de alguns erros que resultaram na consolidação de uma expressão - "ordem pública" - com conceito vago e indefinível que, posteriormente, infligiu verdadeiro suplício à inteligência dos juristas que se ocuparam em analisar seu verdadeiro sentido. ${ }^{159}$

Destaque-se que, ao mesmo tempo em que os juristas reconheceram como árdua a tarefa de definir o real significado e conteúdo do conceito de ordem pública, reconheceram também sua importância para a compreensão do funcionamento dos sistemas jurídicos contemporâneos. Por todas as dificuldades encontradas, alguns afirmaram ser a ordem pública uma "ideia de que se sente, mas que não pode ser definida" ${ }^{160}$, havendo, inclusive, quem visse justamente nesse estado de indeterminação a maior utilidade prática do instituto.

Ainda de acordo com Mario Garmendia Arigón, foram muitas as tentativas de definir o conceito, destacando-se três teorias principais. A primeira delas leva em conta a natureza dos interesses envolvidos na relação jurídica, se públicos ou privados, contrapondo a noção de ordem pública, representada pelo interesse coletivo e geral da sociedade, à de ordem privada, relacionada aos interesses particulares dos indivíduos. Segundo tal concepção, a noção de ordem pública estaria vinculada aos ideias de bem

${ }^{159}$ ARIGÓN, Mario Garmendia. Orden público y derecho del trabajo. Montevideo: Fundacion de Cultura Universitaria, 2001. p. 23-25.

${ }^{160}$ MOURLON, F. Répétitions écrites sur le Code Civil. $11^{\text {a }}$ Ed. revista e atualizada por Ch. Demangeat, T. I, Paris, 1880. p. 70 Apud ARIGÓN, Mario Garmendia. Op. cit., p. 25. 
comum e interesse geral ou social, integrando, dessa forma, o direito público, ao contrário da noção de ordem privada, que atenderia exclusivamente a interesses particulares e individuais, próprios do direito privado. ${ }^{161}$

Já pela segunda teoria, a noção de ordem pública estaria vinculada às regras e valores básicos que constituem a essência do ordenamento jurídico que rege determinada coletividade. Essa noção continua atrelada à clássica divisão entre direito público e direito privado, embora, à época de sua formulação, tal divisão já houvesse sido duramente criticada, com base na concepção de que assim como nem todas as matérias de interesse social pertencem ao direito público, não se poderia considerar tão óbvia a vinculação entre esse e a ordem pública.

Ressalte-se que mesmo entre os autores partidários dessa segunda teoria, verifica-se uma sutil divisão de entendimento quanto ao conceito de ordem pública: enquanto para alguns as regras e valores que sustentam o ordenamento jurídico estariam refletidos na moralidade, nos bons costumes ${ }^{162}$ e na harmonia, que garantem a ordem propriamente dita da vida em sociedade, para outros, esse papel seria assumido exclusivamente pelas normas jurídicas de ordem pública, cuja imperatividade seria responsável pela manutenção da própria vida em sociedade.

Por fim, diferentemente das duas primeiras, a terceira teoria não se baseia em fundamentos de ordem social, jurídica ou filosófica para definir o conceito de ordem pública, mas sim em seu aspecto instrumental ou funcional, relacionado ao plano das fontes do direito. Destaca, na verdade, o papel que a ordem pública exerce no atual estado evolutivo do direito: o de garantir a imperatividade de determinadas normas jurídicas.

No direito privado, por exemplo, a ordem pública restringe a atuação da autonomia privada sobre certos aspectos da relação jurídica, os quais são previamente regulamentados por normas jurídicas cujo conteúdo é considerado irrenunciável e indisponível por vontade das partes. Como resultado, as convenções entre

\footnotetext{
161 ARIGÓN, Mario Garmendia. Op. cit., p. 26.

${ }^{162}$ A identificação da ordem pública com os bons costumes suscitou inúmeros questionamentos, vez que nos diplomas legais posteriores ao Código Civil de Napoleão tais conceitos são apresentados como um binômio inseparável, mas não idênticos. Passou-se a analisar o real conteúdo e alcance de cada um desses conceitos, em virtude do que alguns autores chegaram a propor que o estudo da ordem pública, por exemplo, devesse ser realizado não pelos seus fundamentos, e sim por sua função jurídica (Cf. ARIGÓN, Mario Garmendia. Op. cit., p. 28).
} 
os particulares apenas serão reconhecidas pelo direito, com eficácia de lei, somente se observados os postulados de ordem pública.

Ciente da importância, bem como do paradoxo envolvendo a questão, já que, embora nenhum ordenamento tivesse definido expressamente o conceito, nenhum ordenamento seria concebível sem a idéia de ordem pública, Mario Garmendia Arigón elaborou sua própria definição do instituto, com base nas concepções mais difundidas pela doutrina e pela jurisprudência, como:

el conjunto de valores de la vida que por la especial trascendencia que asumen em determinado estadio de la evolución social, pasan a integrar la conciencia jurídica colectica y se constituyen en objetos de tutela privilegiada por parte del Derecho. ${ }^{163}$

Assim, a ordem pública seria formada pelo conjunto de valores, crenças, postulados ou regras mais significativos de determinado grupo social - chamados bens jurídicos -, vinculados a princípios morais e éticos de determinada sociedade, em certo momento histórico. Todos esses elementos constituiriam um esquema básico de preceitos fundamentais e inalienáveis, os quais são identificados como consciência jurídica coletiva.

\subsubsection{Características gerais}

O conceito de ordem pública é considerado único e plural ao mesmo tempo, porque, embora reconheça fronteiras entre os diversos ramos do direito, assume diferentes perfis em cada um deles. Dessa forma, a proteção e os efeitos emanados da ordem pública são diferentes no direito público e no direito privado, assim como no direito internacional privado, se comparado ao direito do trabalho.

Entre os bens jurídicos que compõem a ordem pública verifica-se, ainda, uma hierarquia, garantida por mecanismos de tutela privilegiada. Assim, os princípios e valores mais elevados de uma sociedade normalmente são encontrados no

${ }^{163}$ ARIGÓN, Mario Garmendia. Op. cit, p. 33. 
nível constitucional, constituindo a base estrutural da convivência social e política, protegidos dos casuísmos da lei e de outras fontes concorrentes.

Outrossim, embora não seja possível conceber qualquer ordenamento jurídico sem a ideia de ordem pública, em cada um dos ordenamentos ela assume conteúdo diferente, dependendo das características culturais, históricas, políticas e econômicas, em virtude da impossibilidade de definir um conteúdo universal para o instituto. Nesse sentido, alguns autores entendem que esse dinamismo da ordem pública, não implica, necessariamente, na substituição de um pensamento por outro, ocorrendo, na maioria dos casos, um enriquecimento de seu conteúdo, com a assimilação e incorporação de novos elementos resultantes do desenvolvimento econômico e social. ${ }^{164}$

Analisando a evolução do conceito de ordem pública, é possível identificar a influência de cada um os grandes acontecimentos históricos sobre sua transformação. Enquanto à época da publicação do Código Civil de Napoleão o conceito de ordem pública era formado pelos ideais de proteção à liberdade individual, à soberania do Estado, à família e à moralidade pública, com o desenvolvimento industrial e a intensificação da questão social, no século XIX, a necessária intervenção estatal evidenciou a ordem pública laboral, representada por normas jurídicas que estabeleceram mínimos inderrogáveis pela autonomia privada das partes. Atualmente, integram a ordem pública temas relacionados à ordem econômica, como sistema bancário, política de preços, legislação fiscal e planejamento econômico.

Paralelamente às mudanças gerais no conteúdo da ordem pública, como acima exposto, verificam-se, ainda, transformações pontuais, relacionadas a áreas específicas do direito. Assim, em matéria de direito do trabalho, por exemplo, no âmbito das relações coletivas, certas condutas, outrora consideradas ilícitas, na atualidade, representam o principal meio de promoção e tutela dos interesses dos trabalhadores, como o direito à greve.

Ainda no tocante às características gerais do instituto, a questão do caráter normativo da ordem pública atrai a atenção dos estudiosos, delimitando os contornos da relação entre ela e o direito positivo. Alguns autores defendem que a ordem pública seria integrada somente pelas normas expressamente identificadas como tal, enquanto outros, ao contrário, sustentam que a consagração de determinado postulado

${ }^{164}$ ARIGÓN, Mario Garmendia. Op. cit, p. 40. 
independeria de qualquer declaração legislativa, a qual serviria apenas como elemento de reforço. Além deles, haveria, ainda, um terceiro grupo de autores, segundo os quais a ordem pública seria integrada tanto por normas de direito público, quanto por normas de direito privado, especialmente aquelas relacionadas ao estado e capacidade das pessoas, à organização da propriedade e à boa-fé nos contratos. Para esses, a ordem pública estaria associada a quatro grandes áreas do direito: proteção da liberdade individual, da soberania do Estado, da solidez da família e do respeito à moralidade.

Sobre tais ponderações, Mario Garmendia Arigón julga a qualificação legislativa pouco determinante para definir o caráter de ordem pública de um postulado. Segundo ele, da mesma forma que não poderiam ser consideradas de ordem pública somente as normas qualificadas como tal, existiriam normas que, embora tenham recebido essa rotulação, em sua essência, não sustentariam tal condição, pois contrariam o próprio espírito do instituto de tutelar valores fundamentais da sociedade. Assim, conclui que a ordem pública não se restringiria à norma concreta, transcendendo o direito positivo, o que traduz nas seguintes palavras:

[...] el orden público, integrando el Ordenamiento, desborda los términos rigurosos de la ley imperativa y ofrece...al Juez um cauce amplio para circunscribir la autonomia de la voluntad más allá de los límites establecidos por las leyes expresamente imperativas, permitiéndole aplicar critérios extrapositivos de justicia y equidad, o, com mayor precisión quizá, facilitarle salir de los textos legales y remitiéndole a algo inmanente a la misma ordenación jurídica, hacer posible la flexibilizacións de la interpretación de las mismas conforme a los Principios Generales del Derecho. ${ }^{165}$

A chancela legislativa representa, segundo o autor, um dado importante para o intérprete, notadamente pela posição ocupada pelos legisladores nos sistemas democráticos republicanos, de legítimos representantes da soberania e porta-vozes da sociedade. No entanto, esclarece que a consagração do caráter de ordem pública também poderia resultar de uma normatização indireta, decorrente da análise semântica de determinada norma concreta ou, ainda, do descumprimento de seu postulado.

${ }^{165}$ ARIGÓN, Mario Garmendia. Op. cit., p. 47. 
A par dessa realidade, os modernos sistemas jurídicos previram mecanismos para evitar que o intérprete ou os destinatários da tutela fossem prejudicados pela lentidão do processo legislativo, caso tivessem que esperar que determinado postulado de ordem pública fosse instrumentalizado por uma norma concreta. É esse, pois, o sentido da norma inscrita no $§ 2^{\mathrm{a}}$, do artigo $5^{\circ}$, da Constituição Federal de 1988, segundo a qual os direitos e garantias expressos na Constituição "não excluem outros decorrentes do regime e dos princípios por ela adotados, ou dos tratados internacionais em que a República Federativa do Brasil seja parte." 166

Desse modo, nos casos de omissão do legislador, o próprio sistema previu mecanismos para suprir a deficiência, restando controversa a questão no sentido contrário, ou seja, a de saber se a declaração legislativa sobre caráter de ordem públicacondiciona inexoravelmente as conclusões do intérprete. A resposta a essa questão exige, como esclarece Mario Garmendia Arigón, a análise da função instrumental que se atribui ao direito dentro das realidades sociais. ${ }^{167}$

Em princípio, o direito constitui-se em uma ferramenta que detecta, reconhece e molda as realidades sociais preexistentes; em última análise, estimula mudanças sociais, como demonstrou o direito do trabalho em relação às transformações sociais e econômicas ocorridas principalmente nos séculos XIV e XX. Além das referências às realidades sociais preexistentes, permite ao legislador exercer atividade normativa verdadeiramente criativa, podendo a norma jurídica inovar e, consequentemente, enriquecer a matéria de ordem pública.

O direito não pode ser construído somente por postulados abstratos, desapegados das realidades sociais que lhe deram origem, pois quando o sistema jurídico assume posição contraditória no tocante às realidades sociais, torna-se uma ferramenta inútil, ineficaz e inaplicável. Direito e realidade constituem um binômio inseparável, sendo esta mais uma razão pela qual a chancela legislativa não pode ser considerada elemento absolutamente indispensável ou irrelevante na definição do caráter de ordem pública de determinado postulado. Tal condição deve ser reconhecida pelo intérprete, ao mesmo

\footnotetext{
${ }^{166}$ No mesmo sentido, são os artigos 72 (“La enumeración de derechos, deberes y garantías hecha por la Constitución, no excluye los otros que son inherentes a la personalidad humana o se derivan de la forma republicana de gobierno") e 332 ("Los preceptos de la presente Constitución que reconocen derechos a los individuos, así como los que atribuyen facultades e imponen deberes a las autoridades públicas, no dejarán de aplicarse por falta de la reglamentación respectiva, sino que ésta será suplida, recurriendo a los fundamentos de leyes análogas, a los principios generales de derecho y a las doctrinas generalmente admitidas"), da Constituição da República do Uruguai.

${ }^{167}$ ARIGÓN, Mario Garmendia. Op. cit., p. 47-48.
} 
tempo em que lhe deve ser garantida a possibilidade de análise em concreto da norma positivada, a fim de verificar se, efetivamente, ela carrega consigo o caráter de ordem pública.

Além disso, destaque-se que as normas de ordem pública geralmente são consideradas indisponíveis pela doutrina e pela jurisprudência, que, não raras vezes, utilizam os conceitos de ordem pública e de indisponibilidade absoluta como sinônimos. Contudo, de forma automática, essa associação não é correta, pois, assim como existiriam normas tutelares de valores de ordem pública que não são consideradas indisponíveis, existiriam, ao contrário, normas consideradas indisponíveis cujos bens ou valores tutelados não integram a ordem pública.

A atribuição de efeito de indisponibilidade é, sem dúvidas, um dos principais instrumentos utilizados pelo ordenamento para garantir a tutela dos bens e valores que integram a ordem pública. Doutrina e jurisprudência normalmente tratam a indisponibilidade absoluta como sinônimo de imperatividade e de indisponibilidade. Em qualquer hipótese, aludem à técnica jurídica adotada pelo legislador para garantir a supremacia de determinados bens jurídicos que, por sua importância para formação e sobrevivência em sociedade, não podem ficar à mercê de convenções particulares. Nesses casos, a vontade dos particulares submete-se integralmente às normas legais - positivadas ou não -, restando pouco ou nenhum espaço para livre disposição.

A imposição de limites à autonomia privada das partes, como resultado do efeito de indisponibilidade, ainda comporta gradações variáveis tanto em função dos diferentes estágios de evolução da ciência jurídica, quanto em função da natureza dos bens tutelados. Assim, em algumas situações, o próprio ordenamento jurídico reconhece a necessidade de se resguardar espaço para as convenções particulares, visando, ao contrário do que se possa imaginar, a uma tutela mais eficaz dos bens jurídicos em questão. É justamente o que ocorre no direito do trabalho: em virtude da indisponibilidade apenas relativa de parte de suas normas, reconhece aos sujeitos da relação de trabalho, na esfera individual ou coletiva, a possibilidade de pactuarem condições de trabalho ou melhores condições para o trabalhador, do que aquelas originalmente previstas pela lei.

5.1.2. Ordem pública e direito do trabalho 
O direito do trabalho foi responsável por uma radical transformação ideológica e jurídica da sociedade. Em vista dos questionamentos referentes ao conteúdo então atribuído à ordem pública pelo pensamento liberal, a legislação laboral atribuiu novo conteúdo ao instituto, baseado no valor social do trabalho e na dignificação do homem enquanto trabalhador. Na verdade, quando se tem em mente as razões que levaram a essa transformação, afirma-se que, ao mesmo tempo em que o direito do trabalho é antecedente, é também consequência dessa transformação.

Segundo Mario Garmendia Arigón, a formatação da legislação laboral constituiu-se em um verdadeiro laboratório de ideias, valores e princípios que logo foram reconhecidos por outros ramos jurídicos, dando início a um intenso e contínuo processo de revisitação de toda a teoria geral do direito. Os estudiosos que se debruçaram sobre os problemas da realidade social e que defenderam a implantação da legislação laboral alertaram a sociedade para o fato de que quando um ordenamento jurídico tutela livre e eficazmente a manifestação de vontade de um trabalhador que se obriga a prestar serviços em excessivas jornadas de trabalho ou que o faz mediante recebimento de um salário miserável não está, na realidade, tutelando o valor fundamental da liberdade e, tampouco, o da igualdade. ${ }^{168}$

Era necessário buscar um novo ideal de justiça, mais especificamente, de "justiça social”. A partir desse momento, reconheceu-se como papel do ordenamento jurídico identificar as desigualdades existentes na realidade social, procurando corrigi-las, mediante a consagração de disposições normativas com conteúdo protetor. Para essa tarefa, foi preciso afastar os ideais do liberalismo, vez que a única forma de assegurar a verdadeira igualdade e liberdade entre os sujeitos da relação de emprego seria a regulamentação e a limitação do âmbito reservado à autonomia privada das partes.

As normas jurídicas assumiram, nessa perspectiva, uma posição mais ativa e incisiva. De mecanismo destinado a assegurar a mais absoluta discricionariedade e disponibilidade de direitos e interesses particulares pela via contratual, transformam-se em instrumento de mudança, questionando a capacidade da autonomia privada de consagrar o novo ideal de justiça social.

Se até então eram concebidas apenas como elemento complementar da vontade dos indivíduos, ou até mesmo como uma mera expressão de vontades 
contratuais tácita, emergiram como meio legítimo, útil e eficaz na mudança de realidades sociais, mediante a consagração de tratamentos diferenciados para compensar determinadas desigualdades. Para tanto, foi necessário fortalecer o perfil imperativo de tais normas, manifestado concretamente pela indisponibilidade, ainda que relativa, de seus preceitos. $^{169}$

Cesar Lanfranchi avaliou, com a profundidade necessária, o papel das normas tutelares do direito do trabalho diante das transformações sociais e econômicasAlgunos han señalado que el Derecho del Trabajo es un límite a la libertad de trabajo, porque, al imponer requisitos para la legitimidad de las relaciones de trabajo, restringe y limita la libertad de contratación. La observación es correcta si por libertad se entiende la que proclamó el liberalismo económico de la Revolución Francesa, esto es, la meramente formal, pero es falsa se considera la igualdad y la libertad reales que deben imperar en la vida social. El liberalismo económico [...] descansaba en la falsa creencia de que la libertad jurídica coincidía con la libertad económica y, en consecuencia, con la libertad de contratación. La enseñanza que se deprende de las explicaciones históricas prueba que la libertad de contratación puede únicamente existir entre hombres igualmente libres, o expresado en otras palabras, solamente la igualdad económica conduce a la igualdad jurídica. La exigencia de las necesidades vitales impedirá, en contra de lo que sostuvo el liberalismo económico, que se imponga la libertad, máxime cuando la necesidad es permanente y acompaña al hombre durante toda su vida, pues el trabajador que ve morir de hambre a su familia, aceptará el salario que ofrezcan. Teórica y formalmente, pudo hablar el liberalismo económico de libertad; en la realidad de las relaciones de trabajo no existió y cuando los principios jurídicos no coinciden con la realidad y cuando, en consecuencia, conducen a un divorcio entre el derecho y la vida y, como resultado final, a la injusticia, dejan de ser principios jurídicos y se convierten en medios de opresión. [...] El Derecho del Trabajo no puede ser contemplado como un límite a la libertad de contratación, sino como un esfuerzo para establecer la

${ }^{169}$ ARIGÓN, Mario Garmendia. Op. cit., p. 74. 
igualdad económica de los factores de la producción, Capital y Trabajo, y hacer posible una auténtica libertad de contratación. ${ }^{170}$

Com efeito, o direito do trabalho emergiu com uma vocação francamente limitadora da autonomia privada das partes, pois somente através desta via seria possível impor a nova concepção de ordem pública, evitando que suas disposições fundamentais ficassem ao livre arbítrio dos indivíduos e, dessa forma, tivessem desvirtuado seu verdadeiro sentido. A partir dessa constatação, formou-se um núcleo de direitos trabalhistas indisponíveis às vontades particulares, o qual se insere automaticamente na relação de trabalho e é responsável pela geração de uma identidade coletiva entre os empregados.

Fala-se que o direito do trabalho promoveu uma alteração radical na sociedade porque o ideal de proteção dos trabalhadores - expressão da própria condição humana - redesenhou os contornos da cultura contemporânea legal, inclusive extrapolando o âmbito do direito do trabalho, para atingir uma dimensão mais elevada, parte do espectro global da ordem pública. Segundo Mario Garmendia Arigón, a legislação laboral incorporou, em definitivo, três novos valores sociais ao conteúdo da ordem pública: 1) o trabalho não é uma mercadoria; 2) o trabalho deve ser objeto de proteção jurídica especial; e 3) o critério de justiça social é vetor de regulação do trabalho humano. ${ }^{171}$

\subsubsection{Ordem pública e imperatividade}

A doutrina justrabalhista tende a confundir ordem pública e imperatividade das normas jurídicas. A confusão decorre do fato de que, na maioria dos casos, os estudiosos partem da análise dos efeitos do instituto sobre as normas jurídicas para, somente após, arriscar uma definição. Desse modo, tendem a identificar a ordem pública com os conceitos de imperatividade, intangibilidade, indisponibilidade e irrenunciabilidade. ${ }^{172}$ Entretanto, essa identificação não é correta, sendo necessário

${ }^{170}$ LANFRANCHI, Cesar. La nocion de orden público em derecho del trabajo. In Revista argentina Derecho del Trabajo, T. XX, Bs. As., 1960. p. 165 e ss. Apud ARIGÓN, Mario Garmendia. Op. cit., p. 7576.

${ }^{171}$ Op. cit., p. 149.

${ }^{172}$ ARIGÓN, Mario Garmendia. Op. cit., p. 81. 
distinguir a ordem pública enquanto conceito, do instrumento jurídico por meio do qual se objetiva a tutela dos bens jurídicos que a constituem.

Segundo Egon Felix Gottschalk, a coexistência de normas de ordem pública e normas de ordem privada no direito do trabalho, com a prevalência das primeiras, seria a fonte de toda a confusão. De acordo com ele, ao disciplinar a conduta humana, o ordenamento jurídico tanto pode estabelecer normas de caráter absoluto (jus cogens), as quais prevalecem sobre a autonomia privada das partes, como estabelecer normas que, embora dotadas da mesma validade e eficácia, são passíveis de modificação, derrogação ou substituição pela autonomia privada (jus dispositivum). ${ }^{173}$

Conforme essa classificação, as normas de ordem pública pertenceriam ao jus cogens, impondo-se de maneira absoluta, imperativa e coativa sobre a vontade das partes, porquanto visem a resguardar os valores comuns a toda a sociedade, em detrimento dos interesses individuais dos sujeitos contratuais, enquanto as normas de ordem privada ao jus dispositivum garantiriam a liberdade de estipulação dos sujeitos individuais, bem como a autonomia dos atores coletivos envolvidos na relação trabalhista. ${ }^{174}$ Com base nessa classificação, e tendo-se em conta a relevância dos bens sociais tutelados pela legislação laboral - como a saúde, a vida, a integridade física e moral do trabalhador -, embora pertencente ao direito privado, o direito do trabalho foi por alguns considerado direito público, o que, segundo Amauri Mascaro Nascimento, facilitou a afirmação da inderrogabilidade (absoluta) de suas leis. ${ }^{175}$

Fato é que, embora no direito do trabalho prevaleçam normas de ordem pública, as normas de ordem privada não podem ser completamente afastadas para impedir completamente a livre manifestação das partes, consoante lição de Arnaldo Süssekind:

O Estado moderno, que regula a ordem econômica e social de maneira que sejam respeitados os princípios da Justiça social, conciliando a

${ }^{173}$ GOTTSCHALK, Egon Felix. Norma pública e privada no direito do trabalho. São Paulo: LTr, 1995. p. 187.

${ }_{174}$ Para Evaristo Moraes Filho e Antonio Carlos Flores de Moraes a associação entre direito público/normas cogentes e direito privado/normas dispositivas não é correta. Segundo os autores, no atual direito público encontram-se proposições meramente dispositivas, assim como no direito privado acham-se normas de natureza imperativa (Cf. MORAES FILHO, Evaristo de; MORAES, Antonio Carlos Flores de. Introdução ao direito do trabalho. $9^{\mathrm{a}}$ ed., São Paulo: LTr, 2003. p. 121).

${ }^{175}$ Curso de direito.... Op. cit., p. 412. 
liberdade de iniciativa com a valorização do trabalho como condição da dignidade humana, inclui nos próprios textos constitucionais os preceitos mínimos de proteção ao trabalho, sublinhando, com essa atitude, a preponderância dos preceitos de ordem pública atinentes ao direito do trabalho. Nas relações de trabalho, ao lado do conteúdo contratual, que é livremente preenchido pelo ajuste expresso ou tácito entre as partes interessadas, prevalece, assim, o conteúdo institucional ditado pelas normas jurídicas de caráter imperativo (leis, convenções coletivas, sentenças normativas etc.) cuja aplicação independe da vontade dos contratantes e ocorre ainda que em sentido diverso se manifestem eles. ${ }^{176}$

Por sua vez, a ordem pública, assentada nos valores fundamentais de cujo respeito depende a própria sobrevivência da sociedade, refere-se tanto às normas de ordem pública quanto às normas de ordem privada. Isso porque, mesmo quando o Estado preserva a autonomia privada dos particulares, garantindo sua livre formação e manifestação, valoriza uma expressão da própria personalidade humana, ou seja, um valor de ordem pública.

É certo que a imperatividade absoluta tem sido um dos instrumentos mais utilizados pela ordem pública como mecanismo necessário para garantir a preservação de certos valores, os quais, pela sua importância, não podem ficar à mercê da possibilidade de livre disposição pelos particulares. Ainda, a ordem pública tampouco se restringe ao direito positivo; ao contrário, é possível que uma norma positivada contradiga um preceito de ordem pública, sendo tarefa do jurista discernir se essa circunstância encontra-se legitimada em razões excepcionais ao interesse geral da coletividade, ou se, simplesmente, representa uma transgressão à ordem pública.

\subsection{Principais instrumentos de regulamentação e limitação utilizados pelo direito do trabalho}

Por todas as razões já esposadas, o conteúdo do contrato de trabalho foi amplamente moldado por normas emanadas de centros de positivação

${ }^{176}$ SÜSSEKIND, Arnaldo; MARANHÃO, Délio; VIANNA, Segadas e TEIXEIRA, Lima. Op. cit., p. 198. 
encontrados no grupo social e reconhecidos pela ordem jurídica. Na realidade brasileira, reconhecem-se dois grandes centros: o Estado, por meio da imposição de normas de ordem pública - a maioria delas com força imperativa -, e a autonomia coletiva dos particulares, por meio dos instrumentos coletivos negociados pelos atores sociais.

Nessa análise, há que se ter em mente que lei e norma não se confundem, tratando-se de expressões que guardam entre si uma relação de gênero e espécie. Assim, são normas todas as regras de direito que integram determinado ordenamento jurídico, qualquer que seja seu centro de produção, estejam elas positivadas ou não.

O ordenamento jurídico trabalhista é, dessa forma, integrado por um complexo de normas, em sua maioria de ordem pública, que tanto apresentam caráter proibitivo,como aquelas relacionadas ao trabalho da mulher e do menor, quanto caráter restritivo, já que fixam limites à atuação das partes que têm de ficar aquém ou além deles, conforme a natureza da relação jurídica. Além disso, é integrado ainda por regras morais e princípios jurídicos que visam a proteger os valores fundamentais da sociedade. Desse complexo, resultam limites à autonomia privada, coletiva e individual, dos sujeitos da relação de trabalho.

Nesse cenário, pode-se afirmar que o estudo dos limites que incidem sobre a autonomia da privada no âmbito das relações de trabalho, em certa medida, relaciona-se diretamente ao estudo das fontes do direito do trabalho. Isso porque, o conhecimento de um ordenamento jurídico ou de um setor particular desse ordenamento, com quaisquer objetivos, inicia-se sempre pela análise de suas fontes. ${ }^{177}$

Sobre o tema, Ronaldo Lima dos Santos esclarece ser a expressão "fontes do direito" metafórica, utilizada para designar os modos de formação das normas jurídicas, ou seja, as fontes das quais emanam o direito, como o faz a água de seus centros de produção. Inclusive, tal expressão mostra-se precária na designação de determinadas fontes normativas, como os princípios e os usos e costumes que, na verdade, possuem duplo enquadramento no sistema, como fontes normativas e como elementos de integração jurídica. Mas é justamente em face de tal precariedade que Alf Ross teria definido as fontes do direito como "o conjunto de fatores ou elementos que exercem influência na formulação do juiz da regra na qual ele funda a sua decisão"; tais influências, segundo ele, seriam de 
ordem variada, ora materializadas em normas jurídicas preexistentes, ora em ideias e inspirações. ${ }^{178}$

Ainda que se questione a filiação neo-empirista de Alf Ross, segundo a qual a figura do juiz é marcante na definição da fonte do direito, a definição rosseana evidencia a correlação entre os temas, pois, se tais fatores ou elementos influenciam na formulação da decisão judicial, de forma mais evidente, materializam limites à autonomia privada dos sujeitos da relação de emprego.

Para Orlando Gomes e Élson Gottschalk, a fonte primária, no direito do trabalho, seria a vontade das partes, materializada no contrato, do qual nasce o vínculo de trabalho. ${ }^{179}$ A capacidade produtiva dessa fonte, por sua vez, seria limitada pela produção de outras fontes que, pela sua natureza, poderiam ser denominadas imperativas e divididas em quatro categorias, de acordo com origem e a composição dos órgãos dos quais emanam: i) fontes de produção estatal; ii) fontes de produção profissional; iii) fontes de produção mista; e iv) fontes de produção internacional. Concluem os autores que, não obstante a procedência diversa, todas as normas que limitam a autonomia privada dos sujeitos da relação de emprego, sejam elas ditadas pelo próprio Estado - com caráter de ordem pública -, sejam elas oriundas do concerto entre grupos profissionais ou de órgãos aos quais o Estado delega poder legiferante, são consideradas normas jurídicas, no sentido técnico do termo, razão pela qual suas fontes são também chamadas "fontes normativas". 180

Corroborando esse entendimento, Otavio Pinto e Silva esclarece que a pluralidade de fontes faz com que existam, dentro de uma mesma sociedade, diversas ordens jurídicas, sem, contudo, negar-se a unidade do ordenamento jurídico como um todo. Tal configuração decorre da busca incessante pela superação do fosso que separa o Estado da sociedade: após se reconhecer que apenas o Estado não poderia solucionar todas as questões que afligem a sociedade, abriu-se espaço para que os grupos sociais organizados pudessem estabelecer normas na defesa de seus próprios interesses, as quais, em última análise, limitaram ainda mais a autonomia dos particulares em suas relações individuais.

\footnotetext{
178 ROSS, Alf. Direito e justiça. Trad. Edson Bini, São Paulo: Edipro, 2003. p. 103 Apud SANTOS, Ronaldo Lima dos. Op. cit., p. 90.

${ }^{179}$ Como já exposto no presente trabalho, por ocasião do estudo sobre a natureza jurídica do contrato de trabalho, há autores que defendam a prescindibilidade da formalização de contrato para a materialização de uma relação de emprego.

${ }^{180}$ GOMES, Orlando; GOTTSCHALK, Élson. Curso de direito.... Op. cit., p. 48.
} 
Assim, interessa conhecer quais as fontes normativas e de limitação à autonomia privada do direito do trabalho, pouco importando a relação existente entre elas, como a prevalência de umas sobre as outras, ou, ainda, eventuais classificações doutrinárias a respeito, por exemplo fontes formais e materiais, mediatas e imediatas, principais e subsidiárias etc.

Com isso, não se pretende esgotar a matéria relativa às fontes da legislação laboral, cuja amplitude justifica a existência de incontáveis estudos doutrinários específicos. No presente estudo, a referência às fontes do direito do trabalho será utilizada apenas como ponto de apoio para a abordagem de seu tema central. Diante desse cenário, não obstante também sejam considerados fontes do direito, a doutrina e os atos de autonomia privada individual foram excluídos da análise: a primeira, por carecer de aspecto vinculante, ainda que moral, não resulta limitações à autonomia privada, tanto no âmbito coletivo, quanto no âmbito individual; os segundos, por constituírem o âmbito de incidência dos limites ora referidos.

Feitos esses esclarecimentos, passa-se à análise das principais fontes do direito do trabalho que, na prática, consagram os limites que o ordenamento jurídico impõe à autonomia privada dos sujeitos da relação de emprego, especialmente no âmbito do contrato individual de trabalho.

\subsubsection{Constituição Federal}

Considerada a principal fonte de produção estatal de direito do trabalho, concentra, por consequência, grande número de regras e princípios que limitam a autonomia privada dos sujeitos da relação de emprego. Constitui-se na base sobre a qual encontram sustentação todas as demais instâncias normativas, as quais se subordinam e não podem contrariar seus comandos, salvo com expressa autorização do texto constitucional. No âmbito do direito do trabalho, estabelece um patamar mínimos de direitos individuais trabalhadores, além de normas de organização do sistema de relações coletivas.

No caso brasileiro, a estrutura atual é fruto da ampliação do objeto, ocorrida nos últimos anos, a partir da constatação de que os fins e objetivos do Estado se incluem entre seus elementos essenciais; assim, quanto mais se discutia a finalidade do 
Estado, mais se ampliava o objeto do texto constitucional. Em decorrência desse fenômeno, o qual foi chamado "constitucionalismo social" ${ }^{181}$, verificou-se um crescente processo de elevação do direito do trabalho, a tal ponto de ser a relação de trabalho considerada a de maior relevo constitucional dentre todas as relações de direito privado.

Na Constituição Federal de 1988, o trabalho, como valor social, passou a ser considerado como um dos "fundamentos da República" (artigo 1", inciso IV); foi também incluído entre os "direitos sociais" (artigo $6^{\circ}$ ), além de ser considerado com "primado" da ordem social (artigo 193). A importância do trabalho foi, assim, solenemente afirmada.

Enquanto tais dispositivos constitucionais são considerados normas programáticas, ou seja, sem aplicação concreta, apenas enunciando diretrizes gerais para todo o ordenamento jurídico, os diversos incisos do artigo $7^{\circ}$, da Constituição Federal, que trata dos direitos dos trabalhadores urbanos e rurais, constituem normas auto-executáveis, com aplicabilidade imediata, que atuam como verdadeiros limites à autonomia privada dos sujeitos da relação de emprego. Nesse sentido, destaquem-se os seguintes incisos:

IV - salário mínimo, fixado em lei, nacionalmente unificado, capaz de atender a suas necessidades vitais básicas e às de sua família com moradia, alimentação, educação, saúde, lazer, vestuário, higiene, transporte e previdência social, com reajustes periódicos que lhe preservem o poder aquisitivo, sendo vedada sua vinculação para qualquer fim;

VI - irredutibilidade do salário, salvo o disposto em convenção ou acordo coletivo;

VIII - décimo terceiro salário com base na remuneração integral ou no valor da aposentadoria;

IX - remuneração do trabalho noturno superior à do diurno;

\footnotetext{
${ }^{181} \mathrm{O}$ constitucionalismo social é caracterizado pelo crescente movimento de inclusão de direitos trabalhistas nos textos das Constituições dos países. Teve início com a Constituição do México, de 1917, e foi inspirado na idéia de fazer do direito do trabalho um mínimo de garantias em benefício da classe economicamente mais fraca, incorporando-as na Constituição como forma de protegê-las contra qualquer política do legislador ordinário (Cf. CUEVA, Mario de la. Derecho mexicano del trabajo. México, Porrúa, 1960. p. 120 Apud NASCIMENTO, Amauri Mascaro. Curso de direito.... Op. cit., p. 393-394).
} 
XIII - duração do trabalho normal não superior a oito horas diárias e quarenta e quatro semanais, facultada a compensação de horários e a redução da jornada, mediante acordo ou convenção coletiva de trabalho; XIV - jornada de seis horas para o trabalho realizado em turnos ininterruptos de revezamento, salvo negociação coletiva;

$\mathrm{XV}$ - repouso semanal remunerado, preferencialmente aos domingos;

XVI - remuneração do serviço extraordinário superior, no mínimo, em cinqüenta por cento à do normal;

XVII - gozo de férias anuais remuneradas com, pelo menos, um terço a mais do que o salário normal;

XXI - aviso prévio proporcional ao tempo de serviço, sendo no mínimo de trinta dias, nos termos da lei;

XXIII - adicional de remuneração para as atividades penosas, insalubres ou perigosas, na forma da lei;

XXXIII - proibição de trabalho noturno, perigoso ou insalubre a menores de dezoito e de qualquer trabalho a menores de dezesseis anos, salvo na condição de aprendiz, a partir de quatorze anos;

Como se vê, tais dispositivos, enunciados exemplificativamente, como típicas normas de ordem pública, estabelecem direitos e garantias aos trabalhadores urbanos e rurais, funcionam como patamares mínimos, abaixo dos quais a autonomia privada dos sujeitos da relação de emprego não pode atuar. Se entendidas como direitos individuais, tais disposições serão consideradas, ainda, imutáveis por meio de emendas, nos termos do $\S 4^{\circ}$, do artigo 60, da Constituição Federal, que limita materialmente o poder de reforma constitucional em relação às chamadas "cláusulas pétreas". ${ }^{182}$

Quanto ao tema, Rodrigo Brandão considera que a tutela aos direitos fundamentais foi confirmada pela própria Constituição Federal, ao estabelecer título específico, logo no início de seu texto, para os chamados "direitos e garantias individuais", no qual foram inseridos os capítulos I (“direitos e deveres individuais e coletivos" - $\operatorname{artigo} 5^{\circ}$ ), II ("direitos sociais" - $\operatorname{artigos} 6^{\circ}$ a 11), III ("direitos da

\footnotetext{
${ }^{182}$ Art. 60. (...) $\S 4^{\circ}$ - Não será objeto de deliberação a proposta de emenda tendente a abolir: I - a forma federativa de Estado; II - o voto direto, secreto, universal e periódico; III - a separação dos Poderes; IV - os direitos e garantias individuais.
} 
nacionalidade" - artigos 12 e 13), IV (“direitos políticos” - artigos 14 a 16), e V (“partidos políticos" - artigo 17). Para Brandão, a positivação constitucional dos direitos e garantias individuais teve por objetivo colocar prerrogativas inerentes à dignidade humana acima do poder de deliberação dos órgãos do Estado, de forma a evitar que maiorias políticas ocasionais colocassem em risco a tutela de tais prerrogativas.

Não obstante, esclarece o mesmo autor haver forte controvérsia doutrinária a respeito da interpretação da expressão "direitos e garantias individuais", inscrita no dispositivo constitucional que trata das cláusulas pétreas. Inicialmente, a controvérsia estaria relacionada ao modo de interpretação do dispositivo constitucional. Se literal, apenas os direitos arrolados nos incisos do artigo $5^{\circ}$, da Constituição Federal, seriam considerados cláusulas intangíveis, tendo em vista estabelecerem o rol de direitos e garantias individuais eleito pelo constituinte, não cabendo aos poderes constituídos contrariarem a decisão previamente tomada pelo titular da soberania.

Fortes argumentos contrapõem-se a esse entendimento, com ênfase para o fato de que a atribuição de um peso definitivo ao elemento gramatical esbarra na insuficiência de seu uso exclusivo no âmbito da moderna hermenêutica jurídica, especialmente na hipótese em questão, por três razões principais: i) pela fluidez semântica e a densidade moral dos "direitos e garantias individuais"; ii) pela circunstância de o próprio constituinte haver aberto o elenco de direitos expressos na Constituição, consoante disposto no $\S 2^{\circ}$, do artigo $5^{\circ}$; e, por fim, iii) pela notável imprecisão terminológica do constituinte no que concerne à positivação dos direitos fundamentais do indivíduo. ${ }^{183}$

De outro ponto de vista, o objetivo do constituinte, ao aludir especificamente aos "direitos e garantias individuais", teria sido o de considerar como “cláusulas pétreas" apenas os direitos e garantias individuais propriamente ditos, a exemplo das chamadas "liberdade fundamentais", que impingem ao Estado o implemento de prestações negativas. Assim, tanto os direitos sociais prestacionais, quanto os direitos difusos e coletivos, estariam excluídos do núcleo da Constituição Federal protegido pela imutabilidade.

Não obstante tais divergências, afirma Brandão que, para a doutrina majoritária, o constituinte de 1988 conferiu status de cláusula pétrea aos direitos

${ }^{183}$ São os direitos sociais cláusulas pétreas? Em que medida? Revista eletrônica do Ministério Público Federal.

Disponível em: 〈http://www.prrj.mpf.gov.br/custoslegis/revista/2010/aprovados/2010a_Dir_Pub_Brandao.pdf $>$. Acesso em: 25/10/2011. 
fundamentais de primeira, segunda e terceira geração, sejam eles direitos de defesa ou prestacionais, nos quais estariam incluídos os direitos sociais. Com efeito, de uma leitura sistêmica do texto constitucional depreende-se não haver hierarquia jurídica ou mesmo axiológica entre direitos de defesa e prestacionais, ou de direitos de uma geração em prejuízo dos demais. Ao contrário, revela-se a inclinação do constituinte pela tese da indivisibilidade e interdependência das gerações de direitos fundamentais. ${ }^{184}$

Especificamente em relação aos direitos sociais, desde seu preâmbulo, a Constituição Federal deixa claro que o Estado Democrático de Direito por ela instituído ostenta uma inequívoca dimensão social, já que se destina a "assegurar o exercício dos direitos sociais e individuais, a liberdade, a segurança, o bem-estar, o desenvolvimento, a igualdade e a justiça como valores supremos de uma sociedade fraterna". Para corroborar esse entendimento, Brandão cita o seguinte trecho da obra de Ingo Wolfgang Sarlet:

\begin{abstract}
A denominação direitos fundamentais sociais encontra sua razão de ser na circunstância - comum aos direitos sociais prestacionais e aos direitos sociais de defesa - de que todos consideram o ser humano na sua situação concreta na ordem comunitária (social), objetivando, em princípio, a criação e garantia de uma igualdade e liberdade material (real), seja por meio de determinadas prestações materiais e normativas, seja pela proteção e manutenção do equilíbrio de forças na esfera das relações trabalhistas. Nesse sentido, considerando os aspectos referidos, poderíamos conceituar os direitos fundamentais sociais - na esteira da magistral formulação de J. Miranda - como direitos à libertação da opressão social e da necessidade. ${ }^{185}$
\end{abstract}

\footnotetext{
${ }^{184}$ Nesse aspecto, Brandão esclarece que, embora a composição majoritária do Supremo Tribunal Federal não tenha adotado expressamente a tese de que os direitos fundamentais de distintas gerações são cláusulas pétreas, da sua jurisprudência são extraídos indícios que apontam para sua aceitação. A título de exemplo, cita o julgamento da ADI 939-DF, em que a Suprema Corte declarou inconstitucional a Emenda Constitucional n. 03/93, com base em direito não formalmente previsto como fundamental (anterioridade tributária: artigo 150, III, $b$, da Constituição Federal); com isso, deixou de lado a tese que restringe o rol de cláusulas pétreas aos incisos do artigo $5^{\circ}$, considerando intangíveis os direitos de distintas gerações, conforme voto do Ministro Carlos Velloso (Cf. BRANDÃO, Rodrigo. Op. cit., p. 12-13).

${ }^{185}$ Os direitos fundamentais sociais na Constituição de 1988. In: PASQUALINI, Alexandre et. al. O direito público em tempos de crise: estudos em homenagem a Ruy Ruben Ruschel. Porto Alegre: Livraria Advogado Editora, 1999. p. 149 Apud BRANDÃO, Rodrigo. Op. cit., p. 11-12.
} 
Com isso, revela-se inequívoca a intenção do constituinte de 1988 em veicular um projeto de transformação social destinado a promover a libertação da opressão social e da necessidade. ${ }^{186}$ No tocante às relações trabalhistas, ainda que esse projeto já houvesse se iniciado, com a elaboração de uma legislação infraconstitucional destinada a garantir direitos mínimos aos trabalhadores, com a Constituição de 1988, tais objetivos foram alçados ao primeiro escalão de normas do Estado Democrático de Direito, consolidando-se como limites intransponíveis à autonomia privada individual dos sujeitos da relação de emprego. ${ }^{187}$

\subsubsection{Legislação consolidada}

A Consolidação das Leis do Trabalho é apontada como o principal diploma legal infraconstitucional no âmbito das relações de trabalho. Ao mesmo tempo em que pode ser considerada como uma fonte específica do direito do trabalho, tanto no sentido de centro de produção, quanto no sentido de limitação, conjuga, em seu corpo, outros elementos díspares, também com duplo enquadramento, como fontes normativas e fontes de limitação à autonomia privada das partes, quais sejam: lei, atos administrativos, decisões judiciais, disposições contratuais, princípios, normas gerais do direito, usos e costumes. ${ }^{188}$

Aprovada pelo Decreto-Lei n. 5.452, de $1^{\circ}$ de maio de 1943, a Consolidação das Leis do Trabalho representou a maturidade de uma ordem social que há muito vinha sendo criada no Brasil. O texto consolidado reuniu diversos textos legais preexistentes sobre direitos trabalhistas, além de incluir algumas inovações, em virtude do

\footnotetext{
${ }^{186}$ A Constituição Federal promoveu expressivas modificações no sistema jurídico de relações de trabalho, tais como: a redução da jornada semanal de 48 para 44 horas; a generalização do regime de fundo de garantia, com a conseqüente supressão da estabilidade decenal; a criação de uma indenização prevista para os casos de dispensa arbitrária; a elevação do adicional de horas extras para o mínimo de 50\%; o aumento em 1/3 da remuneração das férias; a ampliação da licença gestante para 120 dias; a criação da licençapaternidade, de 5 dias; a elevação da idade mínima de admissão no emprego para 14 anos; a descaracterização, como forma destinada a incentivar a iniciativa patronal, da natureza salarial da participação nos lucros da empresa; a obrigatoriedade de creches e pré-escolas para os filhos de empregadas; e a inclusão, em nível constitucional, das estabilidades do dirigente da Comissão Interna de Prevenção de Acidentes, do dirigente sindical e das empregadas gestantes. (Cf. FERRARI, Irany, NASCIMENTO, Amauri Mascaro; MARTINS FILHO, Ives Gandra da Silva. História do trabalho, do direito do trabalho e da justiça do trabalho - Homenagem a Armando Casimiro Costa. 2a Ed., São Paulo: LTr, 2002. p. 174).

${ }_{187}$ Fala-se aqui em autonomia privada individual, pois, em alguns temas, a própria Carta Constitucional reserva espaço para a autonomia privada coletiva, como se depreende da leitura dos incisos VI e XIV, do artigo $7^{\circ}$.

${ }^{188}$ SANTOS, Ronaldo Lima dos. Op. cit., p. 92.
} 
que se aproximou a um verdadeiro Código. Foi resultado do trabalho de uma comissão presidida pelo Ministro Alexandre Marcondes Filho que, depois de anos de estudo, remeteu suas conclusões ao Presidente da República, com sugestões de juristas, magistrados, entidades públicas, empresas privadas, associações culturais, entre outros, consoante o seguinte trecho do relatório apresentado:

\begin{abstract}
A Consolidação representa, portanto, em sua substancia normativa e em seu título, neste ano de 1943, não um ponto de partida nem uma adesão recente a uma doutrina, mas a maturidade de uma ordem social há mais de decênio instituída, que já se consagrou pelos benefícios distribuídos, como também pelo julgamento da opinião pública consciente, e sob cujo espírito de equidade confraternizaram as classes na vida econômica, instaurando nesse ambiente, antes instável e incerto, os mesmos sentimentos de humanismo cristão que encheram de generosidade e de nobreza os anais da nossa vida pública e social. ${ }^{189}$
\end{abstract}

Entretanto, conforme apontado por Amauri Mascaro Nascimento, a mutabilidade e a dinâmica da ordem trabalhista exigiram, e continuam a exigir, constantes modificações legais, as quais foram, e continuam sendo, promovidas por outros diplomas infraconstitucionais que alteraram, extinguiram ou acrescentaram dispositivos inseridos no texto consolidado ${ }^{190}$. Dentre os fatores que influenciaram tais modificações, destaca-se a evolução das normas constitucionais. ${ }^{191}$

Amauri Mascaro Nascimento ressalta, ainda, que em alguns momentos históricos o contraste entre o texto constitucional e o diploma consolidado foi patente, tal como durante a vigência da Constituição Federal de 1946, cujos caráter socialdemocrático e medidas de natureza neoliberal, confrontava-se com o pensamento corporativista que baseou a edificação dos principais pontos da Consolidação das Leis do

${ }^{189}$ FERRARI, Irany, NASCIMENTO, Amauri Mascaro; MARTINS FILHO, Ives Gandra da Silva. Op. cit., p. 171.

${ }^{190}$ De acordo com informações obtidas junto ao site do Planalto, desde sua publicação, em 1 de maio de 1943, o texto do Decreto-Lei n. 5.452 já foi alterado por 173 diplomas legais, entre decretos-lei, decretos e leis ordinárias, sendo o último deles, a Lei $\mathrm{n}^{\circ}$ 12.206, publicada em 11 de outubro de 2011, que estabeleceu o aviso prévio proporcional (Disponível em: 〈http://www2.planalto.gov.br/presidencia/legislacao〉. Acesso em: 14/11/2011).

${ }^{191}$ FERRARI, Irany, NASCIMENTO, Amauri Mascaro; MARTINS FILHO, Ives Gandra da Silva. Op. cit., p. 171. 
Trabalho. Atualmente, mesmo diante das inúmeras modificações pelas quais passou toda a legislação infraconstitucional, ainda se verificariam certos contrastes entre ela e a carta Constitucional vigente, pois enquanto esta seria mais sensível aos princípios da autonomia privada coletiva, o texto consolidado, por exemplo, ainda estaria adstrito às ideias que o presidiram na fase de construção do inacabado arcabouço corporativista.

Dentre as normas que compõem a legislação infraconstitucional, a Consolidação das Leis do Trabalho é, sem dúvida, a que contém a maior quantidade de normas imperativas e, consequentemente, de limites à autonomia privada dos sujeitos da relação de emprego. Com efeito, além de regras que estabelecem expressamente condições mínimas de trabalho, tais como aquelas relativas à jornada, o texto consolidado estabelece outras que, muito embora não estabeleçam limites concretos, delimitam o campo de atuação da autonomia privada das partes na negociação das relações de trabalho (individuais ou coletivas). Nesse sentido, são paradigmáticos os artigos $9^{\circ}$, 444, e 468 do diploma consolidado.

$\mathrm{O}$ artigo $9^{\circ}$ refere-se de forma genérica aos preceitos contidos no texto, estabelecendo apenas indiretamente os limites a serem observados pelas partes na relação de trabalho. Destaque-se que a parte mais importante do artigo em questão referese à sanção que comina aos atos praticados com o objetivo de desvirtuar, impedir ou fraudar a aplicação de tais dispositivos, qual seja, a nulidade de pleno direito, ainda que se saiba, conforme já exposto, que a natureza especial da relação de emprego não se coaduna com a retroatividade dos efeitos da decretação da nulidade.

Já sobre o artigo 444, a seguinte lição de Antonio Lamarca dispensa esclarecimentos adicionais:

Nossa lei é minudente, pouco deixando à livre manifestação de vontade das partes. Em que pese o art. 444, já citado, e segundo o qual "as relações contratuais de trabalho podem ser objeto de livre estipulação das partes interessadas em tudo quanto não contravenha às disposições de proteção ao trabalho, aos contratos coletivos que lhes sejam aplicáveis e às decisões das autoridades competentes", indagamos: o que sobra para as partes, no direito do trabalho de nosso país? Muito pouco. Está claro que a lei não impede a outorga de favores superiores àqueles do direito positivo; mas, quem está disposto a superar e a transcender as garantias 
mínimas da legislação laboral, se com isso corre o risco de ficar em situação de inferioridade na concorrência dos demais comerciantes e industriais do ramo? ${ }^{192}$

Sobre o espaço reservado à autonomia privada, Estevão Mallet não chega a contradizer a lição de Antonio Lamarca, contudo, analisa o disposto no artigo 444 sob outro ângulo - menos limitador, por assim dizer, da autonomia privada das partes do contrato de trabalho: a elas cabe estabelecer as condições em que se dará a prestação de serviços, "preenchendo os espaços vazios deixados pelas normas imperativas". 193

Por fim, o artigo 468 declara serem nulas as alterações contratuais pactuadas ainda que por mútuo consentimento, que acarretem prejuízos diretos ou indiretos ao empregado. Em outras palavras, trata-se do sentido mais estrito da "irreversibilidade do nível de tutela atingido", referida por Maria do Rosário Palma Ramalho. ${ }^{194}$ Nesse caso, a relativização do princípio da autonomia da vontade objetiva suavizar a posição de inferioridade em que normalmente se encontra o empregado. ${ }^{195}$

Em seus comentários sobre Consolidação das Leis do Trabalho, Eduardo Gabriel Saad afirma que o mundo do trabalho tem vasta gama de situações e circunstâncias com reflexo no contrato celebrado entre empregado e empregador, razão pela qual nem sempre o princípio da inalterabilidade teria de ser observado à risca. Segundo ele, deve-se analisar, no caso concreto, se realmente é ilícita a alteração do contrato de trabalho proposta pelo próprio empregado, com vista a solucionar um problema pessoal. Como exemplo, cita a hipótese de empregado que começa a frequentar a escola, ficando impossibilitado de cumprir jornada de oito horas; para contornar a dificuldade, o próprio empregado propõe a diminuição de jornada em duas horas, com a correspondente diminuição salarial, na proporção do número de horas efetivamente trabalhadas. ${ }^{196}$

\subsubsection{Legislação não-consolidada}

\footnotetext{
192 LAMARCA, Antonio. Contrato individual.... Op. cit., p. 28.

${ }^{193}$ Contrato de trabalho, autonomia.... Op. cit., p.

${ }^{194}$ Direito do trabalho - Parte I.... Op. cit., p. 54.

${ }_{195}$ LAMARCA, Antonio. Op. cit., p. 164-165.

${ }^{196}$ SAAD, Eduardo Gabriel. Op. cit., p. 651.
} 
A legislação não-consolidada é também fonte normativa do direito do trabalho e, consequentemente, de limitações à autonomia privada dos sujeitos contratuais, especialmente pelo fato de também concentrar grande número de normas de ordem pública, de caráter cogente, que regulam aspectos diversos da relação de emprego. O termo "não-consolidada" foi utilizado por Orlando Gomes e Élson Gottschalk em referência a todas as normas jurídicas que ficaram "desgarrados" da Consolidação das Leis do Trabalho, por três possíveis razões: i) em virtude de sua índole especial, que não permitiu se entrosassem no texto consolidado; ii) por terem sido promulgados posterior e separadamente; ou ainda, iii) por veicularem matéria conjuntural mais consentânea com os regulamentos da administração pública. ${ }^{197}$

Nesse contexto, destacam-se as leis, os regulamentos e as medidas provisórias.

As leis são produzidas pelo Poder Legislativo, em consonância com as regras fundamentais previstas pela Constituição Federal. ${ }^{198}$ Depois da Constituição Federal, são consideradas as principais fontes estatais do direito do trabalho (incluindo-se aqui a Consolidação das Leis do Trabalho), desempenhando importante papel na formação de tal ramo do direito. Contudo, por serem baseadas em caracterizações tipológicas das relações sociais, suas limitações têm caráter geral, muitas vezes não adequado para algumas relações de trabalho subordinado. Nesses casos, sendo rígidos os limites impostos à autonomia privada individual, recorre-se, quando possível, a fontes extra-estatais, que imprimem a vontade das categorias interessadas.

Já os regulamentos, elaborados por órgãos do programa de governo da Administração Pública, reúnem normas jurídicas produzidas por meio de processos específicos, distintos daqueles legislativos. Essas são concebidas como atos do Poder Executivo, com o objetivo de completar a lei, esmiuçando alguns detalhes, sem, contudo, ampliá-la ou restringi-la. Mediante essa atividade, materializam-se limites a serem observados pelos sujeitos da relação de emprego.

Segundo Otavio Pinto e Silva, os regulamentos podem assumir diversas formas (decretos, circulares, portarias, resoluções e instruções normativas), provenientes de diversos órgãos da Administração Pública, especialmente os do Poder

${ }^{197}$ GOMES, Orlando; GOTTSCHALK, Élson. Curso de direito.... Op. cit., p. 51.

${ }^{198}$ Segundo Otavio Pinto e Silva, embora os entes sociais até possam influir na elaboração das leis, através de "lobbies", sua produção continua reservada a um órgão externo à relação social (Cf. A contratação coletiva como fonte do direito do trabalho. São Paulo: LTr, 1998. p. 26). 
Executivo, que desenvolvem intensa atividade normativa no Brasil, dentre os quais se destaca o Ministério do Trabalho e Emprego. ${ }^{199}$ Além de fiscalizar o cumprimento da lei, com poder de sancionar os infratores em âmbito administrativo, o Ministério do Trabalho e Emprego edita normas de ordem pública que limitam a autonomia privada individual, especialmente em assuntos relacionados à saúde e segurança do trabalho. ${ }^{200}$

Finalmente, as medidas provisórias, inseridas no ordenamento jurídico pátrio por meio do artigo 62, da Constituição Federal de 1988, representam o poder atribuído ao Poder Executivo de editar atos com força de lei, em casos de relevância e urgência, com efeitos imediatos. Consideradas fontes do direito do trabalho, ainda que de caráter excepcional, podem, eventualmente, estabelecer limites à autonomia privada das partes da relação de emprego - seja em âmbito individual, seja em âmbito coletivo -, sendo tais limites perpetuados com a conversão da medida provisória em lei.

Amauri Mascaro Nascimento esclarece que a divisão de competência legiferante depende em grande parte do tipo de Estado. No caso brasileiro, federalista, formado por União, Estados, Municípios e Distrito Federal, consoante dispõe o artigo 22, inciso I, combinado com o parágrafo único, da Constituição Federal, a competência para legislar sobre direito do trabalho é da União, podendo ser atribuída aos Estados-membros em questões específicas, mediante autorização de lei-complementar. ${ }^{201}$

\subsubsection{Princípios}

Celso Antônio Bandeira de Mello ensina que os princípios são, por definição, mandamentos nucleares de um sistema, verdadeiros alicerces cujas disposições se irradiam sobre diferentes normas; compõem o espírito e servem de critério para a exata compreensão e inteligência do sistema normativo, definindo sua lógica e racionalidade. Para o mesmo autor, a desatenção a um princípio implica ofensa não apenas a um

\footnotetext{
${ }^{199}$ SILVA, Otavio Pinto e. Op. cit., p. 28.

200 A título de exemplo, cite-se a Portaria n. 3.214, de 8 de junho de 1978, que aprovou 28 Normas Regulamentadoras do Capítulo V, Título II, da Consolidação das Leis do Trabalho, relativas à Segurança e Medicina do Trabalho, considerando as especificidades de diversos tipos e locais de trabalho.

${ }^{201}$ Curso de direito.... Op. cit., p. 406-407.
} 
específico mandamento obrigatório, mas a todo o sistema de comando, constituindo a mais grave forma de inconstitucionalidade, dependendo do escalão do princípio atingido. ${ }^{202}$

Os princípios têm em comum com as regras jurídicas o caráter de generalidade, entretanto, a generalidade de ambos é distinta: enquanto as primeiras são estabelecidas para um número indeterminado de atos ou fatos, aplicando a uma situação jurídica determinada, os princípios, ao contrário, comportam uma série indefinida de aplicações.

Há, ademais, duas espécies de princípios: os princípios gerais do direito e os princípios especiais de uma disciplina jurídica. Em ambos os casos, nem sempre estão insertos explicitamente no ordenamento jurídico; quando expressos, são conhecidos como "princípios-normas" e sobre eles se afirma estarem formulados da linguagem dos direito; não expressos, são considerados "proposições descritivas", as quais emergem da linguagem dos juristas.

Quando o artigo $8^{\circ}$, da Consolidação das Leis do Trabalho, atribui aos princípios a tarefa de preencher lacunas, mais do que isso, confere-lhe a capacidade de reajustar moldes jurídicos inadequados à proteção dos trabalhadores, restabelecendo a eficácia da regra de direito. Sob esse prisma, acaba por limitar a autonomia privada dos sujeitos da relação de emprego.

No estudo dos princípios e do papel que desempenham no ordenamento jurídico, na maioria dos casos, vem acompanhado da enumeração dos tipos de princípios, as quais variam muito de autor para outro. Na seara do direito do trabalho, por exemplo, o leque de princípios especiais se amplia muito, assim como a importância dada a cada um deles, dependendo do autor e do momento histórico em que ele tenha elaborado sua obra.

Assim, Américo Plá Rodrigues, autor da primeira grande construção jurídica a respeito dos princípios do direito do trabalho, em obra de 1975, sustenta a existência de um princípio maior - princípio protetor -, além de outros subprincípios: in dúbio pro operario, prevalência da norma favorável ao trabalhador, preservação da condição mais benéfica, princípio da realidade, da razoabilidade e da irrenunciabilidade dos direitos trabalhistas. Já autores contemporâneos, como Bernardo

\footnotetext{
${ }^{202}$ MELLO, Celso Antonio Bandeira de. Curso de direito administrativo. $7^{\mathrm{a}}$ ed., São Paulo: Malheiros Editores, 1995. p. 537-538 Apud SILVA, Luiz de Pinho Pedreira. Principiologia do direito do trabalho. $2^{\text {a }}$ ed., São Paulo: LTr, 1999. p. 12.
} 
da Gama lobo Xavier e Maria do Rosário Palma Ramalho, contestam a supremacia atribuída inicialmente o princípio protetor, reposicionando-o em outro patamar, com sobreposição do princípio da razoabilidade..$^{203}$

E não se trata somente de atribuir grau de importância distinto; diferentes posições doutrinárias implicam, também, em diferentes tipificações dos princípios. Assim, conceituando os princípios como "valorações materiais fundamentais", 204 Maria do Rosário Palma Ramalho sustenta a existência, no direito do trabalho português, de três princípios especiais que, por sua vez, apresentam desdobramentos ou subprincípios: 1) princípio da compensação da posição debitória complexa das partes no vínculo laboral; 2) princípio do coletivo; e 3) princípio da autotela laboral. O primeiro princípio ainda se desdobraria nos seguintes: 1.1) princípio da proteção ao trabalhador; e 1.2) salvaguarda dos interesses de gestão do empregador. Destes, o primeiro se desdobraria novamente nos seguintes: 1.1.1) o da segurança no emprego; 1.1.2) o da suficiência salarial; 1.1.3) o da conciliação vida profisisional com a vida privada e familiar; o da 1.1.4) assistência ao trabalhador; e 1.1.5) o do favor laboratoris.

Além dessas construções teóricas, há inúmeras outras que, da mesma forma, adotam tipificações específicas, sendo impossíveis mencionar todas no presente estudo. Contudo, a comparação entre as duas construções teóricas expostas ainda que em linhas gerais - revela diferentes concepções sobre o tema: enquanto Américo Plá Rodrigues adota concepção universalista e unilaterialista, exposta pela supremacia absoluta do princípio da norma mais favorável, Bernardo da Gama lobo Xavier e Maria do Rosário Palma Ramalho, considerados críticos contemporâneos, adotam concepção dialética e multilateral, com base na realidade do direito positivo que, como demonstram, apresenta exceções mesmo ao caráter absoluto do princípio protetor (nesse sentido, citam como exemplo norma inserta em alguns ordenamentos jurídicos, como o brasileiro, a qual admite a derrogação in pejus de normas legais pelas convenções coletivas). ${ }^{205}$

De todo modo, independentemente da tipificação proposta, fato é que elas não chegam a se contradizer, podendo apenas acrescer algum aspecto à classificação mais tradicional; na maioria dos casos, os subprincípios nada mais

\footnotetext{
203 NASCIMENTO, Amauri Mascaro. Curso de direito.... Op. cit., p. 449-450.

${ }^{204}$ RAMALHO, Maria do Rosário Palma. Da autonomia dogmática do direito do trabalho. Coimbra: Almedina, 2000. p. 965.

${ }^{205}$ NASCIMENTO, Amauri Mascaro. Curso de direito.... Op. cit., p. 452-453.
} 
representam do que uma análise sob ângulo muito específico sobre determinada questão que, em última análise, já estava inserida na concepção mais tradicional e genérica - como aquela adotada por Américo Plá Rodrigues. A título de exemplo, não se questiona que os subprincípios da segurança no emprego, da suficiência salarial, da conciliação vida profisisional com a vida privada e familiar, da assistência ao trabalhador e do favor laboratoris, enunciados por Maria do Rosário Palma Ramalho, representam aspectos específicos do princípio geral da proteção ao trabalhador. O acréscimo doutrinário, no caso da referida autora, refere-se aos princípios do coletivo e da autotutela laboral e ao subprincípio da salvaguarda dos interesses de gestão do empregador.

Em qualquer caso, representam verdadeiros limites à autonomia privada dos sujeitos da relação de emprego, com mais intensidade na esfera individual, posto que, consoante acima mencionado, em algumas hipóteses, são abertas exceções em benefício da autonomia privada coletiva, o que não ocorre no âmbito do contrato individual de trabalho.

A esse respeito, toma-se como paradigma o (sub)princípio da irrenunciabilidade: como poder de autoregulamentação dos próprios interesses, a autonomia privada compreende algumas prerrogativas, dentre as quais se destaca o poder de disposição, que consiste em fazer sair do próprio patrimônio um bem social que a ele pertence, mediante o negócio jurídico de disposição. O aspecto negativo desse poder é a indisponibilidade, a qual atua como verdadeira limitação da autonomia privada individual, pois impede um sujeito, com legitimação e capacidade adequadas, de efetuar total ou parcialmente atos de disposição sobre um determinado direito. Daí a irrenunciabilidade, a intransigibilidade, a incedibilidade, a impenhorabilidade, a insequestrabilidade e a incompensabilidade, que têm como consectários os direitos indisponíveis quando absolutos. Faltando uma ou alguma dessas características, por força da lei, a indisponibilidade não será mais absoluta, mais relativa. ${ }^{206}$

A indisponibilidade de direitos, que é absoluta quando se tratar de direitos personalíssimos (quando estritamente vinculados à pessoa) e de alguns direitos patrimoniais (como os benefícios previdenciários), está fundada no interesse do titular do direito, no interesse de um terceiro e no interesse geral, com independência de que, mediatamente, por detrás de cada limitação, haja um interesse geral apoiando-a. Mais do

${ }^{206}$ SILVA, Luiz de Pinho Pedreira. Op. cit., p. 123. 
que isso, todas as limitações ao poder de disposição poderiam ser subsumidas em uma só: a ordem pública. ${ }^{207}$

Ainda que para alguns autores os conceitos de imperatividade, intangibilidade, indisponibilidade e irrenunciabilidade possam ser tomados como sinônimos, identificando a ordem pública, como alhures mencionado, Luiz de Pinho Pedreira da Silva considera que a indisponibilidade, ainda que relativa, a imperatividade e a inderrogabilidade das normas de direito do trabalho, "todas praticamente de ordem pública”, na verdade, conjugam-se para produzir a conseqüência da irrenunciabilidade dos direitos do trabalhador, como um dos princípios cardiais do mesmo direito. ${ }^{208}$

Inicialmente concebida por uma necessidade de ordem pública de reequilibrar a posição das partes na relação de emprego, a legislação trabalhista armou o trabalhador de superioridade jurídica, capaz de compensar sua inferioridade econômica e hierárquica. Assim, dotou o trabalhador de direitos que, em sua maioria indisponíveis e inderrogáveis pelas partes, são por ele irrenunciáveis. Contudo, essa inderrogabilidade acaba se opondo até mesmo ao trabalhador, com o propósito de evitar que ele, pela sua imprevidência ou por um interesse de maior ganho imediato, renuncie aos direitos decorrentes das limitações legais de ordem pública. Luiz de Pinho Pedreira da Silvaafirma que, com isso, o legislador considerou a integridade pessoal do trabalhador um bem preeminente, colocando-o ao abrigo de qualquer atentado, mesmo quando provenha da própria parte interessada. ${ }^{209}$

Por fim, Santoro Passarelli ensina que a disposição dos direitos trabalhistas - com as limitações à autonomia privada individual que ela acaba relevando compreende uma questão de ordem lógica: não seria coerente que o ordenamento conferisse tutela específica e de natureza imperativa ao trabalhador, considerando-o como necessitado e economicamente débil, e, depois, deixasse seus direitos em seu próprio poder ou ao alcance de seus credores. ${ }^{210}$

\subsubsection{Normas coletivas}

207 AVILÉS, Antonio Ojeda. La renuncia de derechos del trabajador. Instituto de Estudios Políticos. Madrid, 1971. p. 61 Apud SILVA, Luiz de Pinho Pedreira. Op. cit., p. 123.

208 Op. cit., p. 124.

209 Op. cit., p. 125.

${ }^{210}$ Nozzione di diritto del lavoro. 6a ed., Nápoles: Jovene, 1952. p. 211 Apud SILVA, Luiz de Pinho Pedreira. Op. cit., p. 126. 
De antemão, esclareça-se que a presente abordagem restringe-se à circunstância de os instrumentos coletivos imporem limites à autonomia privada dos sujeitos do contrato de trabalho, o que se traduz, em outras palavras, na autonomia privada coletiva impondo limites à autonomia privada individual no âmbito das relações de trabalho. Assim, não estão em pauta os limites que o ordenamento jurídico impõe à autonomia privada coletiva, não obstante sua importância.

Como já consignado, paralelamente à atuação estatal, fortaleceu-se a atividade normativa dos particulares no campo das relações coletivas, fazendo com que parte significativa da relação contratual de trabalho fosse moldada por instrumentos de regulamentação coletiva, ou seja, convenções e acordos coletivos, os quais já definidos no item 3.1 do deste trabalho.

A importância da negociação coletiva como fonte de direito do trabalho já foi reconhecida com unanimidade pela doutrina. De acordo com Orlando Gomes e Élson Gottschalk, trata-se do processo de criação de normas pelos próprios interessados, tal como ocorre em relação aos usos e costumes, contudo, de maneira mais rápida e voluntária, razão pela qual são chamadas fontes autônomas do direito. ${ }^{211}$

As normas coletivas limitam a autonomia privada individual na medida em que se incorporam aos contratos de trabalho sob sua jurisdição e são inderrogáveis pela vontade dos particulares, exceto para estabelecer condições mais favoráveis do que aquelas previstas no instrumento coletivo.

Conforme lição de Carnellutti, as convenções e acordo coletivos têm corpo de contrato e alma de lei ${ }^{212}$, em razão do que suas normas têm a mesma eficácia da lei, inclusive quanto à possibilidade de imposição de limites à autonomia privada dos sujeitos da relação de emprego. Não por outra razão, o artigo 619, da Consolidação das Leis do Trabalho, estabelece a primazia da convenção coletiva de trabalho sobre os contratos individuais vigentes, enquanto o artigo 622, do mesmo diploma legal, prevê a aplicação de multa tanto para os empregados quanto para os empregadores que celebrarem

${ }^{211}$ GOMES, Orlando; GOTTSCHALK, Élson. Curso de direito.... Op. cit., p. 52.
${ }^{212}$ SANTOS, Ronaldo Lima dos. Op. cit., p. 218. 
contratos individuais de trabalho com disposições contrárias àquelas previstas nos instrumentos coletivos. $^{213}$

\subsubsection{Jurisprudência}

Tão controvertida quanto a definição da jurisprudência (sentenças individuais, coletivas e súmulas) como fonte de direito do trabalho é a questão de considerá-la como fonte de limitação à autonomia privada individual das partes no âmbito da relação de emprego. ${ }^{214}$ Segundo a noção clássica da separação dos poderes, não seria função do Poder Judiciário elaborar normas jurídicas, mas apenas aplicá-las. A respeito do tema, para Otavio Pinto e Silva, dizer que o Juiz não cria direito, mas apenas aplica aquele preexistente, é desconsiderar toda a atividade criativa que está implícita em sua função e é autorizada pelo próprio ordenamento jurídico. ${ }^{215}$ Com efeito, nos casos de lacuna da lei, o artigo $8^{\circ}$ da Consolidação das Leis do Trabalho autoriza o Juiz a recorrer à equidade para decidir determinadas questões, por meio da qual se atenua a rigidez das fontes escritas, para adaptá-las aos fatos concretos. Assim, ao utilizar a equidade, o juiz cria uma norma para o caso concreto, passando a decisão judicial a ser considerada como fonte do direito do Trabalho. Nessa linha de raciocínio, Otavio Pinto e Silva vai além:

[...] ao proferir qualquer sentença, o juiz sempre estará criando Direito, uma vez que - mesmo fora das hipóteses de lacuna da lei - muitas vezes se mostra possível a utilização de um dispositivo legal em detrimento de outro, para solucionar uma situação concreta. Ou seja, trata-se de ato de criação "dentro da lei": frequentemente os Tribunais Trabalhistas se deparam, por exemplo, com questões como a da denominada

213 Art. 619. Nenhuma disposição de contrato individual de trabalho que contrarie normas de Convenção ou Acôrdo Coletivo de Trabalho poderá prevalecer na execução do mesmo, sendo considerada nula de pleno direito.

Art. 622. Os empregados e as emprêsas que celebrarem contratos individuais de trabalho, estabelecendo condições contrárias ao que tiver sido ajustado em Convenção ou Acôrdo que lhes fôr aplicável, serão passíveis da multa nêles fixada. Parágrafo único. A multa a ser imposta ao empregado não poderá exceder da metade daquela que, nas mesmas condições seja estipulada para a emprêsa.

${ }^{214}$ Ronaldo Lima dos Santos confirma a discussão, destacando que "a fim de driblar a histórica controvérsia em torno da natureza da jurisprudência e da doutrina como fontes do direito, criou-se a distinção entre fontes imediatas e fontes mediatas, conforme a presença ou não de capacidade imediata de geração de norma jurídica" (Cf. SANTOS, Ronaldo Lima dos. Op. cit., p. 93).

215 Op. cit., p 29. 
"terceirização" de serviços dentro de empresa, ora admitindo-a como legal, ora negando sua validade. ${ }^{216}$

No tocante à imposição de limites à autonomia privada, a análise deve ser feita separadamente em relação às súmulas e às decisões judiciais (sentenças individuais e coletivas).

Em relação às súmulas, quando lhes for atribuído efeito vinculante, evidentemente, constituir-se-ão em limites à autonomia privada dos sujeitos contratuais, seja no âmbito da negociação individual, seja no da negociação coletiva. De outra forma, quando não lhes for atribuído tal efeito, é discutível a imposição de limites; isso porque, conforme aponta Otavio Pinto e Silva, embora inexista o efeito vinculante, hipótese em que mesmo o Juiz será livre para adotar posicionamento diverso na decisão de outros casos, a sociedade tende a receber tais precedentes como direito posto, criando a justa expectativa de serem respeitados. Em virtude disso, ainda que formalmente as súmulas imponham limites à autonomia privada dos sujeitos da relação de emprego, informalmente, ou seja, na prática, acaba por desempenhar esse papel. $^{217}$

No tocante às decisões judiciais, sentenças individuais são aquelas proferidas em dissídios individuais, com âmbito de validez restrito às partes litigantes. Com base nisso, a sentença individual poderia ser considerada fonte de limitação da autonomia privada somente das partes envolvidas no caso concreto, e tão somente na relação estabelecida entre elas, excluindo-se as relações celebradas com tais partes com terceiros.

Entretanto, conforme doutrina de Antonio Vazquez Vialard, citado por Otavio Pinto e Silva, a questão não pode ser analisada de forma tão simplista, sendo necessário distinguir, nas decisões judiciais, entre o verdadeiro fundamento do caso (ratio decidendi) e a afirmação incidental nele contida (obter dicta). Segundo o autor argentino, o verdadeiro fundamento adquire valor exemplar para a decisão de outros casos judiciais, servindo, inclusive, para precisar o sentido do direito - não somente do direito a ser observado pelas partes da lide, no caso concreto, mas do direito enquanto norma de ordem pública a ser observada por todos os membros da sociedade, em suas respectivas

\footnotetext{
${ }^{216}$ SILVA, Otavio Pinto e. Op. cit., p. 30.

${ }^{217}$ Ibidem, p. 29.
} 
relações. ${ }^{218}$ Nesse contexto, a jurisprudência, em sentido amplo, poderia configurar limites à autonomia privada individual dos sujeitos de uma relação de emprego qualquer, desvinculada da lide à qual se refere.

Por fim, quanto às sentenças coletivas, sejam elas normativas ou declaratórias $^{219}$, o papel que desempenham como fonte de limitação à autonomia privada individual dos sujeitos dos sujeitos da relação de emprego equivale ao papel desempenhado pelas normas coletivas, pois, em última análise, as disposições do instrumento jurídico sub judice são as que prevalecem.

\subsubsection{Usos e costumes}

Otavio Pinto e Silva define os usos e costumes como regras de conduta observadas de maneira uniforme e constante pelos membros de determinado grupo social, que as consideram como juridicamente obrigatórias. Prossegue o autor esclarecendo tratar-se de normas jurídicas não escritas, resultado da consciência coletiva de um grupo social e reflexo de um comportamento uniforme. ${ }^{220}$

Conforme já apontado por Ronaldo Lima dos Santos, os usos e costumes têm duplo enquadramento no ordenamento jurídico, sendo considerados fontes normativas e, também, elementos de integração. ${ }^{221}$ Assim, quando a lei nada dispõe sobre determinada matéria, a norma consuetudinária assume o caráter de fonte normativa supletiva, preenchendo a lacuna do direito positivo; por sua vez, quando a lei se refere expressamente ao costume, assume a função de integração da norma escrita.

Em qualquer hipótese, a autonomia privada dos sujeitos da relação de trabalho acaba limitada: indiretamente, pela lei, ou, diretamente, pela norma de direito consuetudinário, que não admitirá pactuações contrárias aos entendimentos já

\footnotetext{
${ }^{218}$ VIALARD, Antonio Vazquez. Tratado de derecho del trabajo. Tomo 2, Buenos Aires: Editorial Astrea, 1982. p. 445-446 Apud SILVA, Otavio Pinto. Op. cit., p. 31.

${ }^{219}$ Sentenças normativas são aquelas proferidas em dissídios de natureza econômica, enquanto as sentenças declaratórias são aquelas proferidas em dissídios de natureza jurídica, pois têm como objetivo a interpretação, pelo Poder Judiciário, de determinada norma convencional. Até a promulgação da Emenda Constitucional n ${ }^{\circ}$ 45/2004, nas decisões proferidas em dissídios de natureza econômica, o Judiciário exercia efetivo poder normativo, consistente no estabelecimento de normas e condições de trabalho para as categorias representadas. Contudo, com as alterações promovidas pela Emenda Constitucional $n^{\circ} 45 / 2004$, tais sentenças deixaram de ser, a rigor, normativas.

${ }^{220}$ Op. cit., p. 35-36.

${ }^{221}$ SANTOS, Ronaldo Lima dos. Op. cit., p. 90.
} 
consolidados. Nesse sentido, o caso concreto relatado por Otavio Pinto e Silva evidencia a força dos usos e costumes, inclusive no sentido de impor limites à autonomia privada dos sujeitos da relação de emprego:

Verificou-se há pouco tempo em São Paulo, quando um grande banco que pretendeu modificar a data de pagamento dos salários de seus empregados, do final do mês para o quinto dia útil do mês subsequente ao trabalhado (ou seja, no prazo máximo definido no artigo 459, parágrafo único, da CLT). Essa medida alterava um hábito consolidado há muitos anos, de maneira que o sindicato dos trabalhadores requereu à Justiça com sucesso - a sua suspensão, alegando que era prejudicial aos empregados, uma vez que estes teriam problemas para manejar os respectivos orçamentos domésticos (como, por exemplo, para o pagamento de contas com data certa de vencimento). A empresa, no caso, viu-se constrangida a continuar o comportamento anteriormente estabelecido. $^{222}$

${ }^{222}$ SILVA, Otavio Pinto e. Op. cit., p. 36. 


\section{A CLÁUSUla de NÃO-CONCORRÊNCIA NO DIREITO DO TRABALHO: QUAIS OS LIMITES À AUTONOMIA PRIVADA INDIVIDUAL?}

$\mathrm{Na}$ atualidade, o desenvolvimento tecnológico caminha de mãos dadas como desenvolvimento econômico. A globalização consagrou o conhecimento como novo fator de produtividade e qualidade, na medida em que os produtos com maior tecnologia agregada são os que geram as maiores receitas. Em função do contrato de trabalho firmado com o empregador, o empregado tem, por vezes, acesso às informações confidenciais mais relevantes da empresa, seja em decorrência da função que exerce, seja apenas em razão de sua condição de empregado, pois a convivência na empresa possibilitalhe partilhar dos segredos empresariais, ainda que não necessite deles para desempenhar suas funções. ${ }^{223}$

A partir desse cenário surgem problemas relativos à preservação dos segredos de negócio do empregador e aos direitos e obrigações que tenham sua origem nas criações intelectuais dos empregados, conforme aponta Estêvão Mallet:

[...] no campo trabalhista, o problema surge, em uma de suas facetas, com a possibilidade de uso de conhecimento adquirido pelo empregado, durante a execução do contrato de trabalho e por conta disso, após a extinção do vínculo empregatício, em benefício não mais do antigo empregador mas, sim, em favor do novo. ${ }^{224}$

Destaque-se que preservação dos segredos de negócio, considerado bem imaterial da empresa, não afeta somente os interesses diretos do empregador, mas também questões de ordem econômica constitucional, em especial a liberdade de trabalho e a livre concorrência.

${ }^{223}$ CARDOSO, Alexandre de Almeida. Dos pactos de não-concorrência nos contratos individuais de trabalho. Tese de Doutorado apresentada ao Departamento de Direito do Trabalho da Faculdade de Direito da Universidade de São Paulo, 2003. p. 2.

${ }^{224}$ MALLET, Estêvão. Cláusula de não-concorrência em contrato individual de trabalho. LTr: Revista Legislação do Trabalho, São Paulo, v.69, n.10, out. 2005, p. 1159. 
Ao lado do dever de não-concorrência, que é inerente à condição do empregado, passa a ser utilizada a cláusula de não-concorrência, a qual é definida como a cláusula contratual "em virtude da qual o empregado se compromete, mediante remuneração, a não praticar, por conta própria ou alheia, após a vigência do contrato de trabalho, ação que implique desvio de clientela de seu antigo empregador". ${ }^{225}$

Esse tipo de cláusula é mais comumente inserido nos contratos individuais de trabalho celebrados com determinados tipos de empregados - normalmente aqueles que ocupam cargos bastante elevados dentro da hierarquia da empresa ou que detêm conhecimentos técnicos específicos -, não obstante a ausência de regulamentação específica no direito do trabalho brasileiro. ${ }^{226}$ É justamente em virtude da completa omissão legislativa que pairam tantas dúvidas quanto à licitude e validade de referidas cláusulas. Nesse sentido, além da análise dos fundamentos legais que autorizam - ou, ao menos, não desautorizam - tais acordos, é necessário analisar, ainda, quais limites incidem sobre a autonomia privada das partes, na fixação dos termos desse tipo de cláusula (ex: abrangência espacial e temporal).

Ressalte-se que o tema da concorrência desleal aparece em vários ramos do direito: (i) no direito penal, o crime de concorrência desleal foi tipificado no artigo 195, da Lei $\mathrm{n}^{\circ}$ 9.279/96; (ii) no direito comercial, são estudadas questões relacionadas à concorrência, especialmente nos casos de sócios que se retiram de uma empresa, obrigando-se a não atuarem em empresa ou iniciarem negócio concorrente; e, por fim, (iii) no direito do trabalho, o tema da não-concorrência aparece tipificado nas hipóteses previstas nas alíneas "c" e "g", do artigo 482, da Consolidação das Leis do Trabalho, os quais configuram hipóteses para a rescisão motivada por justa causa do contrato de trabalho. ${ }^{227}$

Como se vê, a concorrência praticada pelo empregado em detrimento de seu empregador foi objeto da legislação trabalhista exclusivamente no curso da relação contratual, sendo a legislação completamente omissa no tocante às pactuações estabelecidas entre empregado e empregador para após a extinção do contrato de trabalho. Assim, teoricamente, após a cessação do contrato de trabalho, o empregado encontra-se

\footnotetext{
${ }^{225}$ BELTRAN, Ari Possidônio. Dilemas do trabalho.... Op. cit., p. 140.

${ }^{226}$ BELTRAN, Ari Possidônio. Dever de fidelidade, dever de não-concorrência e cláusula de nãoconcorrência. LTr: Revista Legislação do Trabalho, São Paulo, v.66, n.4, abr. 2002. p. 419.

227 MARTINS, Sergio Pinto. Cláusula de não-concorrência inserida no contrato de trabalho. IOBRepertório de Jurisprudência: trabalhista e previdenciário, São Paulo, n.7, abr. 2001. p. 128.
} 
livre para vincular-se, por exemplo, a concorrente de seu empregador. É nesse contexto, que os empregadores buscam a proteção, como meio preventivo, nas cláusulas de nãoconcorrência inseridas nos contratos de trabalho.

Em face da ausência de legislação específica sobre as cláusulas de não-concorrência inseridas nos contratos individuais de trabalho, com projeção de efeitos para além da vigência da relação contratual, a discussão sobre a licitude desse tipo de cláusula exige a análise do direito comparado, bem como dos reflexos jurídicos e sociais do tema, tais como: (i) eventuais conflitos com princípios constitucionais - como o princípio da liberdade de trabalho, inscrito no artigo $5^{\circ}$, inciso XIII, da Constituição Federal, elevado à condição de valor fundamental do ordenamento jurídico e do próprio Estado brasileiro; (ii) a real eficácia na tutela dos segredos de negócio da empresa; e, finalmente, (iii) a proteção dos interesses da coletividade, que constitui o fundamento último das medidas repressivas dos atos de concorrência desleal. ${ }^{228}$

\subsection{Liberdade de trabalho versus a cláusula de não-concorrência}

Impedir ou limitar o exercício de certa atividade profissional pelo empregado, após a extinção de seu contrato de trabalho, coloca em dúvida a licitude de disposição contratual nesse sentido. Primeiro, alega-se inconstitucionalidade, por violação à liberdade de trabalho propagada pelo ao artigo $5^{\circ}$, inciso XIII, da Constituição Federal vigente; segundo, suposto atrito com a regra inscrita no artigo 170, inciso VIII, da mesma Carta Constitucional, que inclui, entre os princípios da ordem econômica nacional, a busca do pleno emprego. Contudo, na visão de Estêvão Mallet, tais conclusões não são corretas; segundo ele, "pode a liberdade de trabalho sofrer, sim, restrições, desde que razoáveis, atendido o interesse público". 229

Como já amplamente exposto no presente estudo, a liberdade de trabalho, enquanto direito individual de se estabelecer, produzir e viver do produto do seu trabalho é decorrente do liberalismo propagado pela Revolução Francesa. A Declaração

${ }^{228}$ CARDOSO, Alexandre de Almeida. Op. cit., p. 2-3.
${ }^{229}$ MALLET, Estêvão. Cláusula de não-concorrência.... Op. cit., p. 1160. 
Universal dos Direitos Humanos consagrou-a como o direito "à livre escolha do emprego, a condições justas e favoráveis de trabalho e à proteção contra o desemprego". ${ }^{230}$

Mais tarde, àquela liberdade inicialmente propagada, considerada absoluta, acresceram-se restrições, de modo que hoje, a Constituição Federal do Brasil, por exemplo, considera ser "livre o exercício de qualquer trabalho, ofício ou profissão, atendidas as qualificações profissionais que a lei estabelecer", consoante disposto em seu artigo $5^{\circ}$, inciso XIII. Aliás, dentre os argumentos que se levantam contra a validade dos pactos de não-concorrência, o mais expressivo é de que eles seriam incompatíveis com o princípio constitucional da liberdade de trabalho, visto implicar limitação à liberdade individual do empregado.

A esse respeito, Regiane Teresinha de Mello João afirma ser pacífico que a liberdade de trabalho no Brasil, à exceção das Constituições Federais de 1824 - que nada dispôs sobre o tema -, não se apresentou de modo absoluto e irrestrito enquanto princípio constitucional. ${ }^{231}$ Nesse sentido, é a lição de José Afonso da Silva:

O que denominamos de liberdade de ação profissional não se encaixa em nenhum dos grupos anteriores das liberdades. Alguns chamam-na liberdade de trabalho. Não é, porém, como a concebemos, porque essa terminologia não exprime bem sua essência e porque não constitui direito social do trabalho [...].

O teor do dispositivo, de si, já demonstra que estamos diante de simples direito individual, não daquilo que a doutrina chama de conteúdo social, pois ali não se garante o trabalho, não se assegura o conteúdo do trabalho, nem a possibilidade de trabalho, nem o emprego tampouco as condições materiais para investidura num ofício ou para a aquisição de qualquer profissão. Isso, sim, seria direito social.

O dispositivo confere liberdade de escolha de trabalho, de ofício ou de profissão, de acordo com as propensões de cada pessoa e na medida em que a sorte e o esforço próprio possam romper as barreiras que se antepõem à maioria do povo.

\footnotetext{
${ }^{230}$ Artigo XXIII da Declaração Universal dos Direitos Humanos, adotada e proclamada pela resolução 217 A (III) da Assembléia Geral das Nações Unidas, em 10 de dezembro de 1948.

${ }^{231}$ JOÃO, Regiane Teresinha de Mello. Cláusula de não-concorrência no contrato de trabalho. São Paulo: Saraiva, 2003. p. 20.
} 
[...] Quanto a saber se há ou não condições de aquisição de ofício ou de profissão escolhida, não é tema que preocupe o enunciado formal da norma. Como todo direito de liberdade individual, a regra se limita a conferi-lo sem se importar com as condições materiais de sua efetividade. Equivale a dizer, como a experiência demonstra, que, na prática, a liberdade reconhecida não se verifica em relação à maioria das pessoas, que não têm condições de escolher o trabalho, o ofício ou a profissão, sendo mesmo obrigadas a fazer o que nem sempre lhes apetece sob pensa de não ter o que comer. ${ }^{232}$

Não obstante, referida garantia ainda deve se compatibilizar com outros princípios - como o da busca do pleno emprego -, além de políticas relacionadas à ordem econômica e social. Neste sentido, destaque-se que, até a Constituição Federal de 1988, incumbia ao Poder Público o encargo de promover a pesquisa e o ensino científico, considerados ramos de atividade cultural, os quais ficavam restritos ao âmbito acadêmico. A Constituição Federal vigente alterou esse panorama e, no capítulo referente à ordem social, tratou do incentivo às empresas no sentido de promoverem o desenvolvimento científico, a pesquisa e a capacitação tecnológica, conforme se depreende do exposto no artigo $218, \S 4^{\circ}$, e no artigo $219^{233}$

Tendo como pano de fundo tais políticas, houve aumentou, por exemplo, no número de empregados ocupados em áreas de pesquisa e de conhecimentos técnicos especializados dentro de empresas privadas, panorama este que passou a justificar a inserção das cláusulas de não-concorrência em contratos individuais de trabalho. ${ }^{234}$

232 SILVA, José Afonso da. Curso de direito constitucional positivo. 19a ed., São Paulo: Malheiros Editores, 2001. p. 259-260 Apud JOÃO, Regiane Teresinha de Mello. Op. cit., p. 20-21.

${ }^{233}$ Art. 218. O Estado promoverá e incentivará o desenvolvimento científico, a pesquisa e a capacitação tecnológica. [...] $\S 4^{\circ}$ - A lei apoiará e estimulará as empresas que invistam em pesquisa, criação de tecnologia adequada ao País, formação e aperfeiçoamento de seus recursos humanos e que pratiquem sistemas de remuneração que assegurem ao empregado, desvinculada do salário, participação nos ganhos econômicos resultantes da produtividade de seu trabalho.

Art. 219. O mercado interno integra o patrimônio nacional e será incentivado de modo a viabilizar o desenvolvimento cultural e sócio-econômico, o bem-estar da população e a autonomia tecnológica do País, nos termos de lei federal.

${ }^{234}$ Tal assertiva é confirmada pelo seguinte trecho da obra de João Batista dos Santos e Juary C. Silva, publicado em 1977: "De mais a mais, modernamente a pesquisa tecnológica é feita de preferência por convênios entre as universidades e as empresas, não no interior destas, de sorte a ser pouco provável que a cláusula em apreço, se introduzida no direito do trabalho, venha a contribuir para o progresso tecnológico entre nós" (Cf. SANTOS, João Batista dos; SILVA, Juary C. Cláusulas restritivas à liberdade de trabalho. LTr, São Paulo, ano 41, p. 599, jan. 1977 Apud JOÃO, Regiane Teresinha de Mello. Op. cit., p. 23. 
Com efeito, Alberto Xavier e Arnoldo Wald lembram que, quando submetida a questão ao Supremo Tribunal Federal, o Ministro Aliomar Baleeiro manifestou-se no sentido de ser compatível tal cláusula com a ordem social prevista na Constituição Federal, conforme o seguinte trecho de seu voto:

Do ponto de vista do desenvolvimento nacional, deveria uma cláusula como esta ser mantida, porque precisamos conhecer todos os segredos da técnica, quer da matemática, quer sobretudo da química. Há grandes empresas onde centenas de indivíduos estão pesquisando produtos novos. [...] Em resumo, o caso denuncia a existência de omissão na Lei trabalhista, e a consequente dificuldade de a solverem os juízes trabalhistas. Não configura, porém, contrariedade à Constituição, capaz de trazer litígio ao STF. ${ }^{235}$

\subsection{Dever de não-concorrência e cláusula de não-concorrência: distinção necessária}

Além do necessário contraponto entre a garantia de liberdade de trabalho e os princípios constitucionais relacionados às ordens econômica e social, a análise sobre a licitude das cláusulas de não-concorrência envolve, ainda, a distinção entre estas e o dever geral de não-concorrência dos empregados.

O dever de não-concorrência na relação de trabalho subordinado é ínsito ao contrato de trabalho, estando diretamente relacionado ao dever de fidelidade, como consequência direta da aplicação do princípio da boa-fé na relação de trabalho, sobre o qual, aliás, Nelson Mannrich também se manifestou:

[...] o contrato de trabalho repousa sobre uma base fiduciária: a confiança mútua permeia as relações entre empregado e empregador. O desaparecimento da confiança implica ruptura do

235 XAVIER, Alberto; WALD, Arnoldo. Pacto de não-concorrência: validade e seus efeitos no direito brasileiro. RT, São Paulo, ano 70, v. 552, p. 37, out. 1981 Apud JOÃO, Regiane Teresinha de Mello. Op. cit., p. 24. 
contrato de trabalho, por iniciativa unilateral de qualquer das partes. $^{236}$

Com efeito, a associação entre o dever de não-concorrência e o dever de fidelidade é bastante explícita na legislação e na doutrina italianas. O artigo 2.105 do Código Civil Italiano, por exemplo, ao tratar da "obbligo di fedeltá", estabelece, na verdade, atos de não-concorrência dos quais deve abster-se o empregado no curso do contrato de trabalho, verbis:

Il prestatore di lavoro non deve trattare affari, per conto proprio o di terzi, in concorrenza com l'imprenditore, né divulgare notizie attinenti all'organizzazione e ai metodi di produzione dell'impresa, o farne uso in modo da poter recare ad essa pregiudizio.

De acordo com Luisa Galantino, o artigo em questão estabelece uma obrigação ao empregado, que é acessória à obrigação principal de prestação dos serviços. ${ }^{237}$ Contudo, Krotoschin, citado por Ari Possidônio Beltran, diverge desse entendimento, afirmando que "contrariamente ao que foi sustentado no passado, não se trata de um mero dever acessório, mas essencial para a configuração do contrato de trabalho que é alicerçado na confiança recíproca e no ânimo de colaboração". ${ }^{238}$

Ainda em relação à doutrina italiana, Giuseppe Santoro-Passarelli sustenta que o dever de não-concorrência deriva, pois, da "obbligo di fedeltá" do empregado e perdura até a extinção da relação de trabalho, enquanto as proibições contidas no artigo 2.105 permanecem após a cessação do contrato de trabalho. ${ }^{239}$

Assim, claro está que, no direito italiano, o dever de nãoconcorrência não se confunde com a cláusula de não-concorrência, de que cuida especificamente o artigo 2.125 do Código Civil Italiano ${ }^{240}$. Isso porque, não obstante esse

\footnotetext{
${ }^{236}$ Dispensa coletiva: da liberdade contratual à responsabilidade social. São Paulo, LTr, 2000. p. 275.

${ }^{237}$ Diritto del lavoro. G. Giappichelli Editore, Torino, 2006. p. 425.

${ }^{238}$ BELTRAN, Ari Possidonio. Op. cit., p. 419.

${ }^{239}$ Diritto dei lavori. G. Giappichelli Editore, Torino, 2004. p. 154

240 Art. 2125. Patto di non concorrenza. Il patto con il quale si limita lo svolgimento dell'attività del prestatore di lavoro, per il tempo successivo alla cessazione del contratto, è nullo se non risulta da atto scritto
} 
dever seja interpretado como uma consequência natural do contrato de trabalho, há situações em que se faz necessária a inserção no contrato de cláusula específica de nãoconcorrência, visando à preservação dos interesses da empresa/empregador mesmo após a extinção da relação de trabalho.

Como acima mencionado, normalmente, tais cláusulas são inseridas nos contratos individuais de trabalho celebrados com determinados tipos de empregados - aqueles que ocupam cargos bastante elevados dentro da hierarquia da empresa ou que detêm conhecimentos técnicos específicos. Embora o conteúdo de tais cláusulas verse sobre situações que já estão entre os deveres do empregado, a pactuação expressa tem por objetivo reiterar essas condições e garantir a conduta do empregado após a extinção do contrato. Em razão disso, Ari Possidônio Beltran defende que, em princípio, não haverá porque se negar validade a tais cláusulas. ${ }^{241}$

\subsection{Análise geral da cláusula de não-concorrência no direito do trabalho estrangeiro e no direito do trabalho internacional}

Em virtude da completa omissão da legislação pátria, é oportuna a análise do direito do trabalho estrangeiro e do direito do trabalho internacional, especialmente em virtude do disposto no artigo $8^{\circ}$, da Consolidação das Leis do Trabalho, que autoriza o Juiz a recorrer ao direito comparado para solucionar os casos de lacuna de lei.

Isso porque, em alguns ordenamentos jurídicos, a exemplo de Itália, França, Portugal e Espanha, a cláusula de não-concorrência foi regulamentada, admitindo-se restrições ao exercício profissional pelo empregado, por determinado período, após a cessação do contrato de trabalho, desde que observadas algumas condições. Assim, segue abaixo análise, em breves linhas, do disposto nos ordenamentos jurídicos acima mencionados, sem prejuízo de outros que admitem esse tipo de pactuação, mas que foram excluídos da presente abordagem.

(2725), se non è pattuito un corrispettivo a favore del prestatore di lavoro e se il vincolo non è contenuto entro determinati limiti di oggetto, di tempo e di luogo. La durata del vincolo non può essere superiore a cinque anni, se si tratta di dirigenti, e a tre anni negli altri casi. Se è pattuita una durata maggiore, essa si riduce nella misura suindicata $(2557,2596$; att. 198).

${ }^{241}$ BELTRAN, Ari Possidonio. Op. Cit., p. 420. 


\subsubsection{Itália}

Conforme já mencionado, a possibilidade de pactuação de cláusulas de não-concorrência (patto di non concorrenza), com efeitos para além do término do contrato de trabalho, está prevista no artigo 2.125, do Código Civil italiano, que estabelece algumas condições para a validade do pacto: a) ser escrito; b) prever retribuição em favor do empregado; c) estar a restrição adstrita a certos limites de objeto, tempo e lugar; d) duração da restrição não pode ser superior a cinco anos, em se tratando de dirigentes, e de três anos, nos demais casos.

A lei italiana não impõe nenhuma condição relacionada à qualificação do empregado, mas impõe a necessidade de limitação do objeto da restrição, tempo de duração e lugar. Assim, não pode o empregador impedir, por meio de cláusula de não-concorrência, que o empregado desempenhe qualquer atividade profissional, ainda que observadas limitações temporais e espaciais. Com isso, objetiva-se permitir que o empregado exerça alguma atividade para a qual tenha preparação profissional, de modo a não ser constrangido a mudar de ramo de atividade, o que implicaria violação do direito ao trabalho, garantido pelo artigo $4^{\circ}$, da Constituição italiana. ${ }^{242}$

\subsubsection{França}

$\mathrm{Na}$ França, é bastante comum a inserção da cláusula de nãoconcorrência nos contratos individuais de trabalho, não obstante a ausência de dispositivo legal específico regulamentando-as, papel este que acaba sendo desempenhado pelas convenções coletivas. ${ }^{243}$ Ademais, atribuiu-se às Cortes Superiores a tarefa de estabelecer os critérios e condições validade desse tipo de cláusula.

Regiane Teresinha de Mello João assinala que as convenções coletivas francesas regulamentam a cláusula de não-concorrência de duas formas distintas: a) instituindo uma interdição de concorrência, sendo desnecessário repetir a cláusula no

\footnotetext{
242 JOÃO, Regiane Teresinha de Mello. Op. cit., p. 82.

${ }^{243}$ BELTRAN, Ari Possidônio. Dilemas do trabalho.... Op. cit., p. 142.
} 
bojo do contrato individual de trabalho; e b) estabelecendo parâmetros para a cláusula de não-concorrência negociada individualmente entre empregado e empregador, hipótese em que qualquer condição estabelecida fora dos parâmetros prefixados invalidará o compromisso assumido.

Da mesma forma que no direito italiano, as disposições relativas aos pactos de não-concorrência existentes no direito francês não restringem a aplicação de referida cláusula a qualquer categoria específica de empregado, ou, ainda, a qualquer ramo de empresa. Podem prever, no máximo, efeitos específicos, dependendo da categoria do empregado.

Além disso, também devem prever limitações quanto a tempo e lugar para vigência da cláusula, bem como conferir ao empregado a possibilidade de exercer alguma atividade para a qual seja capacitado. Embora a maior parte das convenções estipule duração máxima de dois anos, os tribunais podem reconhecer períodos superiores, desde que restrita a área geográfica em que a concorrência é vedada.

Decisão da Corte de Cassação, de 14 de maio de 1992, promoveu significativa alteração na linha de conduta dos julgadores, os quais passaram a exigir, para a validade desse tipo de cláusula, a proteção a interesses legítimos do empregador, sob dois aspectos distintos: a) existência de risco de utilização em proveito de empresa concorrente de conhecimentos adquiridos em decorrência do trabalho para o ex-empregador; b) que o empregado tenha tido estreito contato com a clientela, gerando o risco de desvio desta ao novo empregador. ${ }^{244}$

Por fim, não estando previsto em convenção coletiva o pagamento de retribuição ao empregado, tal condição não será necessária ao reconhecimento da validade da cláusula de não-concorrência. Não obstante, o que se verifica, na prática, no bojo das convenções coletivas, é a previsão de pagamentos mensais ao ex-empregado, durante o período em que perdurar a obrigação de não-concorrência.

\subsubsection{Portugal}

${ }^{244}$ BELTRAN, Ari Possidônio. Dilemas do trabalho.... Op. cit., p. 143 e JOÃO, Regiane Teresinha de Mello. Op. cit., p. 84. 
A cláusula de não-concorrência foi regulamentada pelo artigo 136, do Código de Trabalho de Portugal, publicado em 2009, com as seguintes condições: a) pacutuação por meio de acordo escrito; b) limitações quanto à atividade objeto de restrição; c) garantia de compensação pecuniária, em favor do empregado, durante o período de restrição; d) duração máxima de três anos; e) previsibilidade de risco efetivo do empresário. ${ }^{245}$

Destaque-se que, na hipótese de o empregado exercer outra atividade profissional, após a cessação do contrato de trabalho a que se refere a cláusula de não-concorrência, o empregador poderá reduzir a compensação financeira atribuída ao empregado.

\subsubsection{Espanha}

O artigo 21, do Estatuto dos Trabalhadores espanhol, previu a possibilidade de estipulação da cláusula de não-concorrência (pacto de no competencia) para viger após a extinção do contrato de trabalho ${ }^{246}$. Aproximando-se do ordenamento

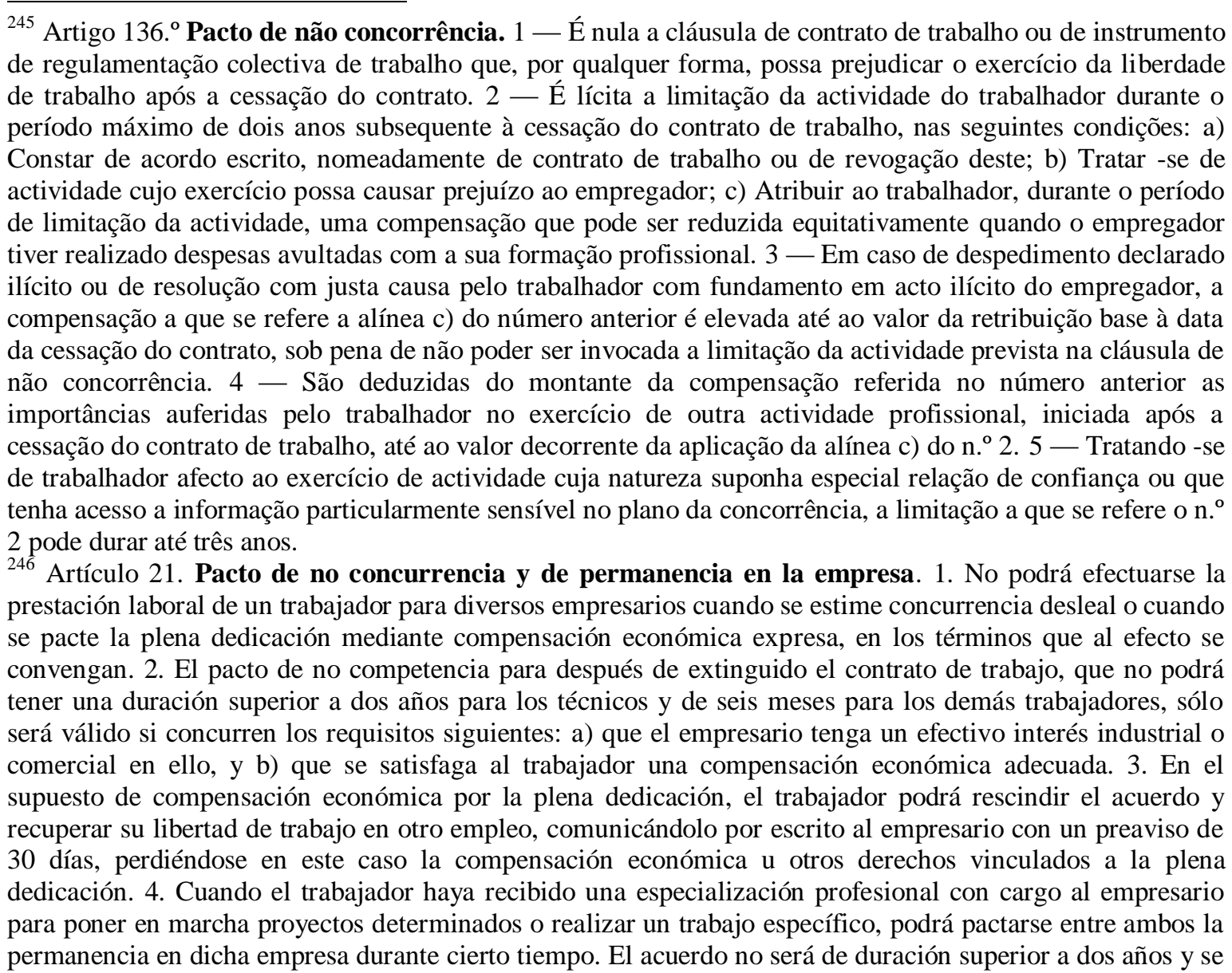


jurídico português, prevê como condições de validade da cláusula: a) estipulação de compensação econômica em favor do empregado; b) efetivo interesse industrial e comercial por parte do empregador; c) período de restrição máximo de seis meses, ou de dois anos, em se tratando de empregado com qualificação técnica.

Interessante notar, igualmente, que o item 4, do mencionado artigo 21, contempla a hipótese de "pacto de permanência", quando o empregado tiver recebido especialização profissional, por conta do empregador, com a finalidade de executar projetos determinados ou realizar um trabalho específico. Nessa hipótese, o empregado deverá permanecer vinculado ao empregador pelo período máximo de dois anos, sob pena de responder pelos danos causados. ${ }^{247}$

\subsubsection{Organização Internacional do Trabalho}

Em 1928, a Organização Internacional do Trabalho adotou resolução favorável à validade da cláusula de não-concorrência inserta nos contratos individuais de trabalho, nos seguintes termos:

Dispositivos legislativos e contratuais tendem, às vezes, a regular a interdição de fazer concorrência, não comente após a cessação do contrato de trabalho, mas também durante a sua duração. Nós nos ocupamos senão das interdições previstas para o período que se segue à cessação do contrato. Quando disposições intervém referindo-se à interdição para um empregado fazer concorrência a seu empregador durante a duração do contrato, nada mais fazem do que precisar ou reforçar medidas gerais de proteção que decorrem do direito comum. Estas medidas parecem de tal modo justificadas que não suscitam nenhuma oposição. ${ }^{248}$

\subsection{A cláusula de não-concorrência no direito do trabalho brasileiro}

formalizará siempre por escrito. Si el trabajador abandona el trabajo antes del plazo, el empresario tendrá derecho a una indemnización de daños y perjuicios.

${ }^{247}$ BELTRAN, Ari Possidônio. Dilemas do trabalho.... Op. cit., p. 143.

${ }^{248}$ Revue Internationale du Travail, v. XIX, Mars, 1929, p. 425 Apud MARTINS, Sergio Pinto. Cláusula de não-concorrência.... Op. cit., p. 127. 
Atualmente, não há na legislação laboral brasileira nenhuma referência à cláusula de não-concorrência inserta em contratos individuais de trabalho. Entretanto, foram várias as tentativas de acrescer o tema às normas relativas aos pactos laborais, mas todas restaram infrutíferas. ${ }^{249} \mathrm{Na}$ legislação atual, o único dispositivo capaz de conferir validade à referida cláusula é o artigo 444, da Consolidação das Leis do Trabalho, que garante liberdade de pactuação aos sujeitos da relação de emprego.

$\mathrm{Na}$ ausência de disposição expressa, e diante da autorização conferida pelo artigo $8^{\circ}$, da Consolidação das Leis do trabalho, os tribunais têm aplicado as orientações do direito comparado em relação aos contratos de trabalho celebrados no território nacional. Assim, a validade desse tipo de cláusula depende da observância de alguns requisitos, os quais são apreendidos do direito comparado. Além disso, a fixação da cláusula deve pautar-se, sempre, pela razoabilidade, de maneira que o seu cumprimento não implique ônus excessivo e injustificado ao empregado, impondo uma limitação geral e absoluta; portanto, não pode levar a uma situação de desequilíbrio entre as partes contratantes. $^{250}$

Da análise do direito estrangeiro, a doutrina pátria estabeleceu as seguintes condições para a validade desse tipo de cláusula:

(i) a adoção da cláusula deve considerar a natureza da atividade atribuída ao empregado, o conhecimento que por conta disso adquire e o uso que poderá fazer de tal conhecimento extinto o contrato de trabalho; ${ }^{251}$

(ii) satisfazer legítimo interesse do empregador;

\footnotetext{
${ }^{249}$ Tanto o Anteprojeto de Código do Trabalho de Evaristo de Moraes Filho, de 1963, quanto o Anteprojeto do Código do Trabalho da Comissão revisora de 1965, formada por Mozart Victor Russomano, Evaristo de Moraes Filho e José Martins Catarino, dispunham sobre a adoção do "pacto de exclusão da concorrência". Da mesma forma, o Anteprojeto de Consolidação das Leis do Trabalho de 1979 previa a "cláusula de nãoconcorrência" (Cf. OLIVEIRA, Oris de. A exclusão da concorrência no contrato de trabalho. Tese de Doutorado apresentada à Faculdade de Direito da Universidade de São Paulo, São Paulo, 1982, p. 176-177 Apud JOÃO, Regiane Teresinha de Mello. Op. cit., p. 38-39).

${ }^{250}$ JOÃO, Regiane Teresinha de Mello. Op. cit., p. 42-43.

${ }^{251}$ MALLET, Estêvão. Cláusula de não-concorrência.... Op. cit., p. 1162.
} 
(iii) a atividade a ser restringida deve ser expressamente determinada, não se admitindo, em hipótese nenhuma, restrições genéricas;

(iv) deve haver uma restrição espacial para a não-concorrência, podendo ser mais ou menos ampla, de acordo com as exigências do caso concreto; ${ }^{252}$

(v) o tempo de duração da restrição também deve ser limitado. ${ }^{253}$

Além dessas condições, impõe-se, como na maioria das legislações, a fixação de uma compensação pecuniária ao empregado, que deverá ser proporcional à restrição imposta e que lhe permita fazer frente aos seus compromissos, como se estivesse trabalhando. Deve-lhe ser possível manter o mesmo nível de vida, pois o pagamento terá natureza alimentar, daí ser adotado como critério de valor a última remuneração do empregado, multiplicada pelo número de meses que deixará de exercer aquela atividade profissional. O pagamento deve ser feito ao término do contrato de trabalho, ou então, mensalmente, em relação ao período em que o empregado deverá cumprir a obrigação de não-concorrência; será devido em qualquer hipótese de rescisão contratual, pois a cláusula diz respeito à não-concorrência após o término do contrato de trabalho e importa que ela seja cumprida

Caso a obrigação não seja cumprida pelo empregado ou, ainda, ele devolva a indenização ou deixe de receber as parcelas restantes, poderá o empregador exigir que cesse a não-concorrência ou responsabilizar o empregado pelas perdas e danos causados.

Como se nota, as limitações impostas ao empregado deverão ser apenas temporária, estabelecidas por consenso entre as partes contratantes, e mediante

\footnotetext{
${ }^{252}$ Segundo Estêvão Mallet, a necessidade de restrição espacial não excluir peremptoriamente a possibilidade de ser pactuada cláusula com abrangência superior ao território nacional nacional, visto que a produção realiza-se hoje com enorme facilidade em diferentes partes do mundo e desloca-se, de um lado para outro, com grande rapidez. Assim em tal contexto, não se justificaria restringir a eficácia da cláusula de nãoconcorrência ao âmbito do território nacional, o que tornaria muito fácil a violação a tal limitação (Cf. Cláusula de não-concorrência.... Op. cit., p. 1163).

${ }^{253} \mathrm{O}$ ideal é que seja estabelecida por um prazo máximo de dois anos, que é o período máximo de vigência do contrato de trabalho celebrado por prazo determinado; contudo, certas atividades não necessitariam de $\mathrm{m}$ prazo muito longo, tais como de produtos de bancos e na área de informática, em que em algumas semanas ou em seis meses os demais concorrentes já absorveram o novo produto ou a nova tecnologia (Cf. MARTINS, Sergio Pinto. Cláusula de não-concorrência.... Op. cit., p. 124).
} 
justa contraprestação de caráter indenizatório. Somente se observados tais requisitos, cumulativamente, a doutrina e a jurisprudência pátrias têm considerado lícita a adoção de referida cláusula, sem que importe em violação à garantia de liberdade de exercício de ofício ou profissão, constante no inciso XIII, do artigo $5^{\circ}$, da Carta Constitucional. 


\section{CONCLUSÕES}

Sobretudo nos campos econômico e tecnológico, é incomensurável o progresso advindo dos dogmas do liberalismo. Entretanto, no campo social, a sociedade ficou marcada por profundas cicatrizes, pois, como em um piscar de olhos, os ideais de liberdade e igualdade, que pretendiam libertar os homens das amarras que pudessem comprometer seu progresso, transformaram o contrato no mais opressivo instrumento de dominação do homem pela via institucionalizada

A construção teórica sobre a plena autonomia para constituir relações contratuais tornou-se, então, inadequada, passando a coexistir com os andaimes de uma concepção antagônica, relacionada à necessidade de controle do exercício dessa liberdade.

Com o objetivo de realizar a função social dos contratos, o Estado viu-se obrigado a intervir nas relações entre os particulares, especialmente na relação de trabalho, que veio a ser considerada como a principal relação de direito privado, por envolver, em sua essência, a disposição, pelo homem, de bem inerente à sua própria constituição: sua força de trabalho.

Assim, para corrigir os males causados - pois, àquela altura, os trabalhadores eram explorados, especialmente na incipiente indústria, até derramarem a última gota de seu suor - e evitar que tais males se perpetuassem - por meio futuras gerações de homens "débeis e ignóbeis" -, o Estado passou a ditar as regras da relação de trabalho, moldando, com amplitude, o conteúdo dos pactos laborais. Nesse momento, a autonomia privada deixa de ser considerada como um poder absoluto, pois o Estado impôs limites além dos quais ela não poderia avançar.

Saliente-se que a nova sistemática dos pactos laborais parte do pressuposto de os pólos da relação contratual são ocupados, invariavelmente, de um lado, pela figura do empregador, detentor do capital e de vasto patrimônio pessoal, e, de outro, pela figura do empregado, um pobre assalariado, que, com o estômago vazio e os pés descalços, não era suficientemente capaz para negociar a forma pela qual disporia de sua força de trabalho. Embora essa fotografia possa parecer por demasiado trágica ou, desconectada da realidade, como se afirma hoje em dia, em algum momento do passado, ela foi o retrato fiel dos grandes centros de produção. 
É com base nesse panorama que se edificou o ordenamento jurídico trabalhista brasileiro, assim como o da maioria dos países capitalistas - sem prejuízo das eventuais modificações nos textos legais que vieram a ser implementadas posteriormente por alguns deles.

Com a regulamentação de aspectos pontuais da legislação do trabalho, especialmente por meio de normas de ordem pública, o Estado reduziu, tanto quanto pode, o espaço reservado ao poder de livre disposição dos particulares, objetivando, com isso, reconduzir a formas pacíficas e equitativas as relações que, até esse momento, apresentavam-se como de violência e de supremacia do mais forte.

Por muito tempo, a abordagem dos limites impostos pela autonomia privada das partes não exigiu grandes esforços por parte dos juristas, pois tais limites podiam ser encontrados, com facilidade, na extensa regulamentação da relação de trabalho. Contudo, as transformações no campo científico, tecnológico, econômico, cultural e social impuseram novas realidades, redesenharam a fotografia original dos grandes centros de produção.

Nesse sentido, toma-se como exemplo o intenso processo de globalização que, acompanhado de outros fatores, consagrou o conhecimento como novo fator de produtividade e qualidade; além disso, acirrou a competição comercial, que instiga a procura por novas tecnologias, não só para atender as necessidades presentes, mas também visando ao futuro.

Destaque-se que o direito, como fruto da realidade, não poderia ficar imune a todas essas transformações. Mais do que nunca, a ordem econômica clamou a atenção do Estado, sendo necessário conciliar seus valores e pressupostos com os de ordem social. Nesse contexto, surgem novos tipos de conflitos, inclusive de natureza trabalhista, para os quais o ordenamento jurídico não tinha resposta imediata.

$\mathrm{Na}$ esfera do direito do trabalho, por exemplo, a imagem tradicional do empregado e do empregador, bem como dos centros de produção (notadamente, o ambiente fabril), não justificavam a existência de grandes elaborações jurídica. Somente era necessário proteger o trabalhador contra os excessos que pudessem vir a ser praticados pelos patrões: excesso de jornadas de trabalho, ausência de períodos de descanso, baixos salários, desamparo em casos de acidente de trabalho, ausência de medidas de segurança e saúde no trabalho, e só. Assim, não se cogitava de conflitos envolvendo obrigação de não- 
concorrência, dever de confidencialidade, direitos de propriedade intelectual e, até mesmo, pagamento de prêmios de incentivos (como se observa da total ausência de disposições legais na legislação trabalhista brasileira a respeito).

As soluções para os novos conflitos começaram, então, a ser elaboradas pela doutrina. Nesse sentido, tome-se como exemplo a classificação elaborada sobre os princípios especiais do direito do trabalho por Maria do Rosário Palma Ramalho; pelas razões já expostas, em outros tempos, era impensável incluir entre os valores fundamentais de um ordenamento jurídico trabalhista, a salvaguarda dos interesses de gestão do empregador. Ainda que esse tipo de preceito não esteja positivado no ordenamento jurídico, a tendência é isso ocorra em questão de tempo, segundo defendem os autores mais entusiasmados com referido progresso.

De qualquer forma, diante das omissões do legislador quanto aos novos tipos de conflitos gerados pelo progresso, propôs o presente estudo que o operador recorra à análise dos limites à autonomia privada consagrados pelo ordenamento jurídico, pois, como se demonstrou por meio da abordagem dos pactos de não-concorrência, a omissão legislativa não implica, necessariamente, repulsão pelo sistema. É necessário, apenas, conhecer quais os limites. 


\section{BIBLIOGRAFIA (CONSULTADA E REFERIDA)}

ABRANTES, José João. Direito do trabalho - ensaios. Lisboa: Cosmos, 1995.

Formação e evolução histórica do direito do trabalho - Direito do trabalho. Ensaios, Lisboa, 1995.

Academia Brasileira de Letras. Vocabulário ortográfico da língua portuguesa. $2^{\mathrm{a}}$ ed., $6^{\mathrm{a}}$ impressão, reimpressão de 1998. Rio de Janeiro: Imprensa Nacional, 1999.

ALMEIDA GUILHERME, Luiz Fernando do Vale de. A limitação da autonomia privada nos direitos reais e pessoais. Revista de Direito Privado. São Paulo, n. 14. p. 281-299, abr.-jun.2003.

AMARAL NETO, Francisco dos Santos. Autonomia privada. Revista do CJF, Brasília, n. 09, set.-dez.1999. Disponível em: <www.cjf.gov.br/revista/numero9/artigo5.htm>. Acesso em: 01/09/2011.

A autonomia privada como princípio fundamental da ordem jurídica: perspectivas estrutural e funcional. Revista de Direito Civil. São Paulo, ano 12, n. 46, p. 07-26, out.-dez.1998.

ANTUNES, Carlos, PERDIGÃO, Carlos. Relações laborais e direito do trabalho. Ano VI, n. 10, mar. 2007.

ARENDT, Hannah. A condição humana. Trad. Roberto Raposo. 10 ed., Rio de Janeiro: Forense, 2009.

ARIGÓN, Mario Garmendia. Orden público y derecho del trabajo. Montevideo: Fundacion de Cultura Universitaria, 2001.

AZEVEDO, Antônio Junqueira de. Negócio jurídico: existência, validade e eficácia. $4^{\mathrm{a}}$ ed., São Paulo: Saraiva, 2002. 
Novos estudos e pareceres de direito privado. São Paulo: Saraiva, 2009.

BARACAT, Eduardo Milléo. A boa-fé no direito individual do trabalho. São Paulo: LTr, 2003.

BARASSI, Ludovico. Il diritto del lavoro. Milano: Giuffrè, 1949.

BARROS, Alice Monteiro. Curso de direito do trabalho. $5^{\text {a }}$ ed., São Paulo: LTr, 2009.

. Curso de direito do trabalho - Estudo em memória de Célio Goyatá. V. I, $2^{\mathrm{a}}$ Ed., São Paulo: LTr, 1994.

BASTOS, Ricardo da Silva. Uma nova visão dos contratos: a autonomia privada. Revista do Instituto de Pesquisas e Estudos, Bauru, n. 30, p.369-374, dez./mar. 2000-2001.

BELTRAN, Ari Possidônio. Dilemas do trabalho e emprego na atualidade. São Paulo: LTr, 2001.

Autotutela nas relações de trabalho. São Paulo: LTr, 1996.

. Dever de fidelidade, dever de não-concorrência e cláusula de nãoconcorrência. LTr: Revista Legislação do Trabalho, São Paulo, v.66, n.4, abr. 2002, p. 419-424.

A relação do direito do trabalho com os demais ramos da ciência jurídica. In: CORREIA, Marcus Orione Gonçalves (org.). Curso de direito do trabalho. V. I, São Paulo: LTr, 2007, p. 155-167.

BESSONE, Darcy. Do contrato: teoria geral. 4ª ed., São Paulo: Saraiva, 1997.

BETTI, Emílio. Teoria geral do negócio jurídico. Trad. Servanda Editora. Campinas: Servanda Editora, 2008. 
BITTAR, Carlos Alberto. Contratos civis. Rio de Janeiro: Forense, 1990.

BONFANTE, Pietro. Diritto romano. Milão: Giuffrè, 1976.

Historia del derecho romano. Trad. Jose Santa Cruz Teijeiro. V. 1 e 2, Madri: Revista del Derecho Privado, 1944.

Instituzioni di diritto romano. Turim: Giappicheli, 1949.

BRANDÃO, Rodrigo. São os direitos sociais cláusulas pétreas? Em que medida? Revista eletrônica do Ministério Público Federal. Disponível em: <http://www.prrj.mpf.gov.br/custoslegis/revista/2010/aprovados/2010a_Dir_Pub_Bran dao.pdf>. Acesso em: 25/10/2011.

CABANELLAS, Guillermo. Tratado de derecho del trabajo. Tomo II, Buenos Aires: El Gráfico, 1949.

CABRAL, Érico de Pina. A "autonomia” no direito privado. Revista de Direito Privado, São Paulo, n. 19, p. 83-129, jul.-set. 2004.

CARDOSO, Alexandre de Almeida. Dos pactos de não-concorrência nos contratos individuais de trabalho. Tese de Doutorado apresentada ao Departamento de Direito do trabalho da Faculdade de Direito da Universidade de São Paulo, 2003.

CATHARINO, José Martins. Contrato de emprego. $2^{a}$ ed., Rio de Janeiro: Edições Trabalhistas, 1965.

CESARINO JUNIOR, Antonio Ferreira. Natureza jurídica do contrato individual de trabalho. Rio de Janeiro: A. Coelho Branco, 1938.

COELHO, Luciano Augusto de Toledo. Contrato de trabalho e a autonomia privada. Revista do Tribunal Regional do Trabalho da $9^{a}$ Região, Curitiba, v. 29, n. 53, p.243-284, jul./dez. 2004. 
CORRADO, Renato. La nozione unitaria del contratto di lavoro. Unione tipograficoeditrice torinese, 1956

CORRÊA, Adriana Espíndola. Reflexão sobre as potencialidades da informação como tutela da autonomia privada no âmbito contratual. Revista da Faculdade de Direito da Universidade Federal do Paraná, Curitiba, v. 33, p. 121-133, 2001.

DELGADO, Mauricio Godinho. Curso de direito do trabalho. $6^{a}$ ed., São Paulo: LTr, 2007.

Contrato de trabalho: caracterização, distinção, efeitos. São Paulo: LTr, 1999.

ECO, Umberto. Como se faz uma tese. 15ª ed., São Paulo: Perspectiva, 1999.

FARIA, Roberta Elzy Simiqueli de. Autonomia da vontade e autonomia privada - uma distinção necessária. In Direito Civil: Atualidades II. César Fiuza, Maria de Fátima Freire de Sá, Bruno Torquato de Oliveira Naves (Coord.). Belo Horizonte: Del Rey, 2007, p. 55 71.

FERNANDES, António Monteiro. Direito do trabalho. $13^{\text {a }}$ ed., Coimbra: Almedina, 2007.

. Noções fundamentais de direito do trabalho. Coimbra: Almedina, 1976.

FERRARI, Irany, NASCIMENTO, Amauri Mascaro; MARTINS FILHO, Ives Gandra da Silva. História do trabalho, do direito do trabalho e da justiça do trabalho Homenagem a Armando Casimiro Costa. $2^{\text {a }}$ Ed., São Paulo: LTr, 2002.

FERREIRA, Waldemar Martins. Tratado de direito comercial. V. 14, São Paulo: Saraiva, 1965.

FRANÇA, Pedro Arruda. Contratos atípicos. $3^{\mathrm{a}}$ ed., Rio de Janeiro: Forense, 2000. 
FRANÇA, Rubens Limongi. Autonomia da vontade - princípio fundamental da obrigação contratual. In FRANÇA, Rubens Limongi (org). Enciclopédia Saraiva de Direito. São Paulo: Saraiva, 1977.

FRANCESCHELLI, Vincenzo. I rapporti di fatto - Ricostruzione della fattispecie e teoría generale. Milano, 1984.

GALANTINO, Luisa. Diritto del lavoro. Turim: Giappichelli, 2006.

GARCEZ NETO, Martinho. Autonomia da vontade. In SANTOS, J. M. de Carvalho Santos; DIAS, José de Aguiar (coord). Repertório Enciclopédico do Direito Brasileiro. V. V, Rio de Janeiro: Editor Borsoi, 1947.

GARCIA, Gustavo Filipe Barbosa. Curso de direito do trabalho. $4^{\mathrm{a}}$ ed., Rio de Janeiro: Forense, 2010.

GOMES, Julio Manuel Vieira. Direito do trabalho - Relações individuais de trabalho. V. I, Coimbra: Coimbra, 2007.

GOMES, Orlando e GOTTSCHALK, Élson. Curso de direito do trabalho. São Paulo: Forense, 1968.

GOMES, Orlando. Contratos. 26 ${ }^{\mathrm{a}}$ ed., Rio de Janeiro: Forense, 2008.

GOTTSCHALK, Egon Felix. Norma pública e privada no direito do trabalho. São Paulo: LTr, 1995.

GRAU, Eros Roberto. O direito posto e o direito pressuposto. $5^{\text {a }}$ ed., São Paulo: Malheiros Editores, 2003.

GUEDES, VAZ. A prestação do trabalho e a sua transformação pacífica pelo direito civil. Lisboa, 1914, p. 23-44. 
HIRATA, Alessandro. Relações contratuais fáticas. Tese apresentada para Concurso para Professor Titular junto ao Departamento de Direito Civil da Faculdade de Direito da Universidade de São Paulo, 2011.

JOÃO, Regiane Teresinha de Mello. Cláusula de não-concorrência no contrato de trabalho. São Paulo: Saraiva, 2003.

. Tratado práctico de derecho del trabajo. Buenos Aires: Depalma, 1965.

LACERDA, Dorval de. A falta grave no direito do trabalho. Rio de Janeiro: Revista do Trabalho, 1947.

LAMARCA, Antônio. Contrato individual de trabalho. São Paulo: Revista dos Tribunais, 1969.

LEITE, Carlos Henrique Bezerra. Clausula de não-concorrência no contrato de trabalho. IOB - Repertório de Jurisprudência: trabalhista e previdenciário. São Paulo, n.13, p. 287-284, jul. 1999.

LIMA, Taisa Maria Macena de. A nova contratualidade ma reconstrução do direito privado nacional. Revista Virtuajus. Belo Horizonte, ano 3, n. 1, jul.2004, Disponível em: <http://www.fmd.pucminas.br/Virtuajus/virtuajus inicio.html $>$. Acesso em: 01/09/2011.

LOPES, Otavio Brito. Limites constitucionais à negociação coletiva. Revista Jurídica Virtual, Brasília, vol. 1, n. 9, fevereiro 2000. Disponível em: < http://www.planalto.gov.br/ccivil_03/revista/Rev_09/neg_coletiva_Otavio.htm>. Acesso em 18/11/2011.

MAGALHÃES, Daniel de Castro. Contratos coletivos de trabalho no sistema jurídico italiano: derrogabilidade/inderrogabilidade e flexibilização. In Revista Tribunal Superior do Trabalho, Brasília, v. 72, n. 2, maio/ago, 2006.

MAGANO, Octavio Bueno. Manual de direito do trabalho. Parte Geral, v. I, São Paulo: LTr, 1993. 
MAIUCCI, Luigi. Le fonti del diritto del lavoro. Prima ristampa, Torino: G. Giappichelli, 1988.

MALLET, Estêvão. Cláusula de não-concorrência em contrato individual de trabalho. LTr: Revista Legislação do Trabalho, São Paulo, v. 69, n.10, out. 2005, p. 1159-69.

- Contrato de trabalho, autonomia privada e remuneração; formas de remuneração variável; remuneração variável sujeita a revisão periódica; interpretação do contrato de trabalho; conduta das partes e conteúdo da contratação. In Prática de direito do trabalho. São Paulo: LTr, 2008.

MANNRICH, Nelson. A modernização do contrato de trabalho. São Paulo: LTr, 1998. Inspeção do trabalho. São Paulo: LTr, 1991.

Dispensa coletiva: da liberdade contratual à responsabilidade social. São Paulo, LTr, 2000.

MARCA, Mauricio Machado. A aplicação do princípio da igualdade às relações de trabalho como limitador a autonomia privada à luz da jurisprudência do Tribunal Superior do Trabalho. LTr: Revista legislação do trabalho, São Paulo, v. 72, n. 7, p. 805814, jul. 2008.

MARTINEZ, Pedro Romano. Código do Trabalho anotado. $2^{a}$ ed., Coimbra: Almedina, 2004

. Direito do trabalho. $3^{\text {a }}$ ed., Coimbra: Almedina, 2006.

O contrato de empreitada no direito romano e no antigo direito português Contributo para o estudo do conceito de obra na empreitada - Direito e justiça. VII, 1993, p. 17-33. 
MARTINS, Sergio Pinto. Cláusula de não-concorrência inserida no contrato de trabalho. IOB - Repertório de Jurisprudência: trabalhista e previdenciário, São Paulo, n.7, abr. 2001, p. 128-124.

MARTINS-COSTA, Judith. A Boa-Fé como Modelo (uma aplicação da teoria dos modelos, de Miguel Reale). Revista Brasileira de Direito Comparado, n. 211, Rio de Janeiro: Instituto Comparado Luso Brasileiro, 2002.

A universalidade e a construção do biodireito. Bioética, Brasília, v. 8, n. 2, p.

229-246, 2000 , Disponível em:

〈http://revistabioetica.cfm.org.br/index.php/revista_bioetica/article/viewFile/278/277> . Acesso em: 01/09/2011.

Crise e modificação da idéia de contrato no direito brasileiro. Revista de Direito civil, imobiliário, agrário, e empresarial, São Paulo, n. 59, jan./mar., 1992.

- O método da concreção e a interpretação dos contratos: primeiras notas de uma leitura suscitada pelo código civil. In: DELGADO, Mário Luiz Delgado; ALVES, Jones Figueiredo (Coord.). Questões controvertidas no direito das obrigações e dos contratos. São Paulo: Método, 2005, p. 127-155.

MATOS, Albertino de. Contratos de trabalho e previdência corporativa. Coimbra: Coimbra, 1937.

MELGAR, Alfredo Montoya. Derecho del trabajo. $2^{a}$ Ed., Madrid: Tecnos, 1978.

MELO FILHO, Hugo Cavalcante. Limitações legais a autonomia privada coletiva. Revista da Esmape, Recife, v. 2, n. 3, p. 191-199, jan./mar. 1997.

MINHARRO, Francisco Luciano. A Propriedade intelectual no direito do trabalho. São Paulo: LTr, 2010. 
MIRANDA, Custódio da Piedade Ubaldino. Autonomia privada: conceito, atuação e limites. Revista da Faculdade de Direito de São Bernardo do Campo, São Bernardo do Campo, v. 7, n. 9, p. 53-60, 2003.

MONTEIRO FERNANDES, Antonio Lemos. Direito do trabalho. V. I e II, Coimbra: Almedina, 1994.

MONTOYA MELGAR, Alfredo. Derecho del trabajo. Madrid: Tecnos, 1993.

MORAES FILHO, Evaristo de; MORAES, Antonio Carlos Flores de. Introdução ao direito do trabalho. 9ª ed., São Paulo: LTr, 2003.

NASCIMENTO, Amauri Mascaro. Contrato de trabalho. São Paulo: LTr, 1970.

Curso de direito do trabalho. $25^{\text {a }}$ ed., São Paulo: Saraiva, 2010.

NASSIF, Elaine Noronha. Fundamentos da flexibilização: uma análise de paradigmas e paradoxos do direito e do processo do trabalho. São Paulo: LTr, 2001.

NICOLINI, Giovanni. A contratação coletiva no ordenamento italiano. In: FREDIANI, Yone; ZAINAGHI, Domingos Sávio (Coord.). Relações de direito coletivo Brasil-Itália. São Paulo: LTr, 2004, p. 75-86.

NORRIS, Roberto. Curso de direito do trabalho. São Paulo: LTr, 1998.

OLEA, Manuel Alonso; BAAMONDE, Maria Emilia Casas. Derecho del trabajo. $18^{\mathrm{a}}$ ed., Madri: Civitas, 2000.

OLIVEIRA, Oris de. A exclusão da concorrência no contrato de trabalho. Tese de Doutoramento na Faculdade de Direito da Universidade de São Paulo, 1982.

PERA, Giuseppe. Compendio di diritto del lavoro. Milão: Giuffrè, 1992. 
PEREIRA, Caio Mário da Silva. Instituições de direito civil. V. 1, Rio de Janeiro: Forense, 1996, p. 301.

PRATA, Ana. A tutela-constitucional da autonomia privada. Coimbra: Almedina, 1982.

RAMALHO, Maria do Rosário Palma. Da autonomia dogmática do direito do trabalho. Coimbra: Almedina, 2000.

Direito do trabalho - Parte I - Dogmática geral. $2^{\circ}$ Ed., Coimbra: Almedina, 2009.

Direito do trabalho - Parte II - Situações laborais individuais. $3^{\mathrm{a}}$ Ed., Coimbra: Almedina, 2010.

RIBAS, Christina Miranda. Em torno da autonomia privada. Revista Jurídica da UEPG, Ponta Grossa, v. 1, n. 1, p. 201-213, 1997.

RIBEIRO DE VILHENA, Paulo Emilio. Relação de emprego: estrutura legal e supostos. São Paulo: Saraiva, 1975.

ROBORTELLA, Luiz Carlos Amorim. A flexibilização no direito do trabalho: crise econômica, novas tecnologias e política social do Estado. Revista LTr: legislação do trabalho e previdência social. São Paulo. V. 54, n.4, p.430-434, abr. 1990.

RODRIGUES JUNIOR, Otavio Luiz. Autonomia da vontade, autonomia privada e autodeterminação - Notas sobre a evolução de um conceito na modernidade e na pósmodernidade. Revista de informação legislativa, v. 41, n. 163, p. 113-130, jul./set. de 2004.

RODRIGUEZ, Américo Plá. Princípios de direito do trabalho. São Paulo: LTr, 1993.

ROMITA, Arion Sayão. A subordinação no contrato de trabalho. Rio de Janeiro: Forense, 1979. 
As cláusulas normativas da convenção coletiva integram os contratos individuais de trabalho? Revista de Direito do trabalho, São Paulo, v. 27, n. 103, p. 1319, jul./set. 2001.

. Denominação, natureza jurídica e conceito de contrato de trabalho. In MAGANO, Octavio Bueno (Coord.). Curso de direito do trabalho: homenagem a Mozart Victor Russomano. São Paulo: Saraiva, 1985.

Flexigurança - A Reforma do mercado de trabalho. São Paulo: LTr, 2008.

RÜDIGER, Dorothee Susanne. Autonomia privada coletiva e crise paradigmática: direito do trabalho. Revista do Tribunal Regional do Trabalho da $9^{\text {a }}$ Região, Curitiba, v. 29, n. 53, p.71-86, jul./dez. 2004.

RÜGER, André, RODRIGUES, Renata de Lima. Autonomia como princípio jurídico estrutural. In Direito Civil: Atualidades II. César Fiuza, Maria de Fátima Freire de Sá, Bruno Torquato de Oliveira Naves (Coord.). Belo Horizonte: Del Rey, 2007, p. 3-24

RUPRECHT, Alfredo J.. Relações coletivas de trabalho. São Paulo: LTr, 1995.

SAAD, Eduardo Gabriel. Consolidação das Leis do Trabalho Comentada, 44a ed, São Paulo: LTr, 2011.

SANTORO-PASSARELLI, Giuseppe. Diritto dei lavori. Seconda edizione, Torino: G. Giappichelli, 2004.

SANTOS, Ronaldo Lima dos. Teoria das normas coletivas. $2^{a}$ ed., São Paulo: LTr, 2009.

SARMENTO, Daniel. Direitos fundamentais e relações privadas. Rio de Janeiro: Lumen Juris, 2004.

SEVERINO, Antonio Joaquim. Metodologia do trabalho científico. 20 a ed., São Paulo: Cortez, 1996. 
SILVA, Homero Batista Mateus da. Curso de direito do trabalho aplicado. V. 1 - Parte Geral, Rio de Janeiro: Elsevier, 2009.

Curso de direito do trabalho aplicado. V. 6 - Contrato de trabalho, Rio de Janeiro: Elsevier, 2009.

SILVA, José Afonso da. Curso de direito constitucional positivo. 19a ed., São Paulo: Malheiros Editores, 2001.

SILVA, Luiz de Pinho Pedreira da. Principiologia do direito do trabalho. São Paulo: LTr, 1999.

SILVA, Otavio Pinto e. A contratação coletiva como fonte do direito do trabalho. São Paulo: LTr, 1998.

SILVA, Walküre Lopes Ribeiro da. Autonomia privada, ordem pública e flexibilização do direito do trabalho. In Faculdade de Direito da PUC/RS: O ensino jurídico no limiar do novo século. Antonio Paula Cachapuz de Medeiros (org.), Porto Alegre: EDIPUCRS, 1997, p. 211-222.

STELLA RITCHTER, Giorgio. Contributo allo studio dei rapporti di fatto nel diritto privato. In Rivista trimestrale di diritto e procedura civile, 1977, p. 151 e ss.

STRENGER, Irineu. Da autonomia da vontade. São Paulo: LTr, 2000.

SÜSSEKIND, Arnaldo; MARANHÃO, Délio; VIANNA, Segadas. Instituições de direito do trabalho. São Paulo: LTr, 1999.

VASQUEZ, Vialardi. Derecho del trabajo. 2a ed., Buenos Aires: Astrea, 1981.

WALD, Arnoldo e XAVIER, Alberto. Pacto de não-concorrência - validade e seus efeitos no direito brasileiro. In Revista dos Tribunais, São Paulo, n. 552/32. 
XAVIER, Bernardo da Gama Lobo. Curso de direito do trabalho. $2^{\mathrm{a}}$ ed., Lisboa: Verbo, 1993.

Iniciação ao direito do trabalho. Lisboa: Verbo, 1994.

Fontes eletrônicas consultadas:

BASE DE LEGISLAÇÃO DO PLANALTO. Disponível em:

<http://www2.planalto.gov.br/presidencia/legislacao $>$.

MINISTÉRIO DO TRABALHO E EMPREGO. Disponível em: 〈www.mte.gov.br〉.

TRIBUNAL SUPERIOR DO TRABALHO. Disponível em: 〈www.tst.gov.br〉. 